

\section{Materiales y técnicas constructivas en la Murcia andalusí (siglos $\mathrm{x}$-xIII)}

\section{Materials and building techniques in the andalusian Murcia (10-13th centuries)}

\author{
Julio Navarro Palazón* \\ Pedro Jiménez Castillo \\ Escuela de Estudios Árabes de Granada (CSIC)
}

\section{Resumen:}

En el presente trabajo estudiamos la evolución de los materiales y técnicas constructivas en la Murcia andalusí, durante un periodo de tiempo que se extiende entre los siglos $x$ y XIII, para lo que nos basaremos especialmente en la rica información extraída de las numerosas excavaciones efectuadas en dicha ciudad, que se refiere sobre todo a arquitectura residencial. Tras su exhaustivo análisis hemos identificado algunas diferencias entre las fábricas de los siglos X y XI y las posteriores de los siglos XII y XIII, por lo que consideramos importante describirlas, señalando a la vez los elementos que las caracterizan. También trataremos los problemas que plantea la datación absoluta de estos aparejos, señalando los datos seguros de que disponemos al respecto. Con el fin de analizar hasta qué punto son generales estas observaciones o si por el contrario responden más bien a fenómenos de regionalización del registro material andalusí, cotejaremos los datos conseguidos en Murcia con los procedentes de otros yacimientos andalusíes alejados del área de estudio. Finalmente, comprobaremos si existen o no diferencias entre el medio rural y el urbano, y para ello compararemos los materiales y técnicas constructivas presentes en dos yacimientos murcianos coetáneos, distantes 40 kilómetros y situados junto al mismo rio Segura: la ciudad de Murcia (una gran medina) y el despoblado de Siyâsa (un hisn).

Palabras clave: Al-Andalus, arqueología, arquitectura, materiales, técnicas constructivas, tapial, mampostería, ladrillo, rural, urbano, Murcia, Siyâsa.

\section{Abstract:}

The evolution of the materials and building techniques of the andalusian city of Murcia between the 9th and 13th centuries are here studied, mainly based on the new information provided by the numerous archaeological excavations that have been carried out in the city for the last thirty years, related especially to residential architecture. After its accuracy analysis, some differences between the buildings techniques manufactured in the 10th and 11th centuries and those later attributed to 12th and 13th centuries have been identified, being thus highly important to describe them by remarking at the same time those distinguishing features. Problems related to the absolute chronology of these building techniques are also discussed, highlighting the definitive information currently known. With the main aim of analysing how general these remarks are or, on the contrary, if they depend on the regionalization phenomenon characterizing the andalusian recording material, we will compare the information obtained in Murcia with those coming from other andalusian sites, located these far away from the studied area. Finally, we will check if there are differences between the rural and urban environments by comparing the materials and building techniques recorded in two coetaneous sites in Murcia, both sited close to the same river Segura and $40 \mathrm{~km}$ distant from each other: the city of Murcia (a large madina) and the deserted settlement of Siyâsa (a hisn).

Key words: Al-Andalus, archaeology, architecture, materials, building techniques, rammed earth wall, rough stone masonry, brick, rural, urban, Murcia, Siyâsa.

* julionavarro@eea.csic.es pedro@eea.csic.es
A lo largo del presente trabajo nos ocuparemos de los materiales y técnicas constructivas en un determinado marco espacial y temporal como es la ciudad de Murcia en época islámica ${ }^{1}$. Al utilizar principalmente como material de estudio los restos arquitectónicos descubiertos en excavaciones arqueológicas, nos vemos obligados a centrarnos principalmente en el análisis de las fábricas de los muros y a dejar a un lado los sistemas de cubrición, pues la inmensa mayoría de los edificios examinados apenas conservan más que sus cimentaciones y zócalos. Las intervenciones realizadas en Murcia durante más de treinta años han permitido documentar los cambios que se han ido produciendo en el empleo de los aparejos edilicios en un medio urbano. Se trata de excavaciones de urgencia que afectan a una ciudad viva como es el caso de Murcia y, por tanto, no fueron planificadas siguiendo estrictos criterios científicos, razón por la cual, la información que proporcionan contiene algunos sesgos. Por otra parte, el carácter intensivo de las intervenciones ha permitido estudiar un potente depósito arqueológico, en cada una de las parcelas excavadas, en el que se puede distinguir perfectamente la superposición de edificios, a la vez que se observan las reformas y reparaciones que sufrieron antes de ser arrasados por completo.

El periodo objeto de estudio se inicia con la fundación de la ciudad de Murcia en el año 825, y llega hasta la conquista castellana de mediados del siglo XIII, aunque es más apropiado afirmar que nuestro trabajo abarcará desde el siglo X al XIII, pues del primer siglo de vida urbana tenemos muy pocos datos. Por este motivo, no vamos a tratar en el presente trabajo algunos fenómenos que se produjeron en al-Andalus durante el siglo IX y principios del $\mathrm{X}$, referidos a los procesos de recuperación de algunos materiales y técnicas constructivas como es el caso de la cantería y la reintroducción del uso de los morteros de cal2.

\footnotetext{
${ }^{1}$ Este trabajo ha sido hecho en el marco del Proyecto de Investigación del VI Plan Nacional de Investigación Científica, Desarrollo e Innovación Tecnológica 2008-2011, titulado «Los palacios en la Baja Edad Media peninsular: intercambios e influencias entre Al-Andalus y los Reinos Cristianos» (HAR2008-01941), cuyo investigador principal es Julio Navarro Palazón. Queremos expresar nuestro más sincero agradecimiento a los evaluadores y al Consejo de Redacción de la revista así como a D. Fermín Font y a D. Ignacio Gil por sus acertadas sugerencias y observaciones a nuestro borrador.

${ }^{2}$ Es interesante subrayar la relación que existió entre la recuperación de estas técnicas y el renacer de la vida urbana en al-Andalus. A este respecto Azuar hace un comentario que se podría aplicar a Murcia: "Los datos arqueológicos confirman que el desarrollo de la construcción en los contextos urbanos, experimentado en alAndalus entre los siglos $I X$ y X, —con la articulación de sus procesos productivos: normalización de caleras, de tejeras o alfares preparados para proporcionar los materiales necesarios para la construcción, y del desarrollo y especialización en los procesos de trabajo-, a diferencia de lo que sucede en el mundo rural, está intimamente unido y sólo es explicable desde la dinámica de formación y consolidación de las ciudades, rasgo fundamental de la creación de la sociedad tributaria de alAndalus» (Azuar, 2009, pp. 29 y 30).
} 


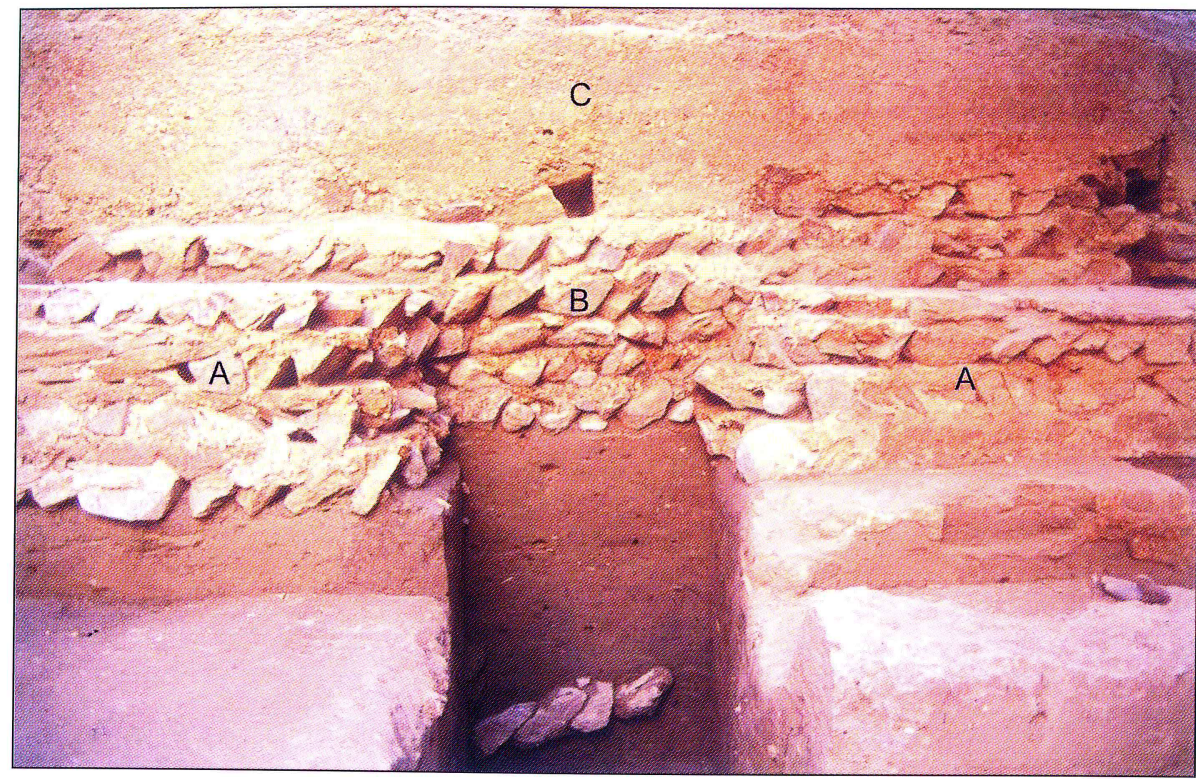

Fig. 1. Casón de Puxmarina (Murcia). Medianería conformada por dos muros adyacentes con cimentación de mampostería (s. x). El proceso de formación es el siguiente:

$1^{\circ}$. Se construye el muro A del que destruimos un pequeño tramo con la finalidad de ver el alzado completo del muro B.

$2^{\circ}$. Al muro A se le adosa el $B$.

3०. En fecha desconocida los propietarios de inmueble más antiguo eliminan el muro $A$ y dejan como medianería el B, ganando así la superficie de la estructura desaparecida.

$4^{\circ}$. Finalmente el alzado de tierra del muro B fue sustituido por una nueva estructura (C) de tapial de hormigón (ss. XII-XIII)
El panorama arquitectónico que presentaremos corresponde plenamente a los siglos X y XI, periodo en el que la ciudad ya ha superado su fase de gestación o constitución ${ }^{3}$.

Aunque la mayor parte de la información que manejaremos procede de la ciudad de Murcia, utilizaremos también la que han proporcionado otros yacimientos del Sureste peninsular, es decir, de lo que en la Edad Media constituyó la cora de Tudmîr y posteriormente el reino de Murcia. Además haremos referencias puntuales a yacimientos especialmente significados del resto de al-Andalus, con el fin de contextualizar los datos extraídos en un marco más general. No obstante, y aunque aún no existen trabajos comparativos, hay indicios de que los resultados de nuestra investigación en el área murciana no siempre se pueden extrapolar en su totalidad a otras zonas de alAndalus, pues en este tema, como en otros que se refieren también al registro arqueológico andalusí, se dieron particularidades regionales más o menos relevantes; aún así, creemos que investigaciones como ésta son necesarias para poder en un futuro abordar con éxito un estudio de carácter más general.

En la actualidad, a pesar de que nuestro conocimiento del tema es parcial e insuficiente, parece que estamos en condiciones de afirmar que existían notables diferencias entre la arquitectura urbana y la rural. Esta última, condicionada por la escasa especialización de los oficios y, sobre todo, por su alejamiento de los centros de produc-

\footnotetext{
${ }^{3}$ Una primera aproximación arqueológica a la Murcia del siglo x la hicimos en un trabajo sobre la Murcia omeya, donde se incluía un capítulo dedicado a las técnicas y materiales constructivos (Jiménez y Navarro, 2001).
}

ción artesanal, estaba obligada a explotar los recursos naturales del entorno más inmediato, por lo que se muestra mucho menos elaborada y más conservadora que la urbana. En este sentido, presentaremos ciertos ejemplos significativos, particularmente el despoblado de Siyâsa (Cieza), cotejando sus características con otros casos de carácter urbano de la misma época, es decir, de los siglos XII-XIII. Sería interesante, sin duda, hacer esta misma comparación para momentos anteriores, pero desgraciadamente en la actualidad no contamos en nuestra zona de estudio con información suficiente para esta fase más temprana, sobre todo en lo referente a conjuntos rurales.

A lo largo de estas páginas también trataremos un aspecto de la historia de la construcción poco conocido, como son las prácticas reparadoras tradicionalmente empleadas para devolver la solidez a los viejos muros, por lo que es especialmente necesario usar una metodología arqueológica apropiada, con el fin de diferenciar las técnicas y materiales utilizados en una obra nueva y los empleados en una reparación, sobre todo cuando la fabrica objeto de estudio está hecha con materiales pobres. En efecto, a diferencia de la arquitectura contemporánea románica y gótica que se hacía en las ciudades de los reinos cristianos, en las que predomina el empleo de la sillería o de la mampostería ${ }^{4}$, los tapiales de tierra, los calicastrados y los adobes, tan habituales en los alzados de los edificios andalusíes, requerían un mantenimiento casi periódico que

\footnotetext{
${ }^{4}$ Conviene insistir en que el adobe y el tapial se emplearon en la arquitectura cristiana bajomedieval, pues con frecuencia algunos fechan en época andalusí los edificios que encuentran por la simple presencia de estos materiales.
} 
ocasionaba frecuentemente su desaparición, suplantados por forros y bataches de ladrillo y/o mampostería.

\section{CONSIDERACIONES GENERALES SOBRE CRONOLOGÍA}

Según veremos, el empleo de materiales y técnicas experimentó ciertos cambios entre los siglos X y XIII, por lo que su estudio permite obtener aproximaciones cronológicas a los edificios en que aparecen. Estos cambios posibilitan una elemental clasificación de las fábricas en dos grupos bien diferenciados que denominaremos antiguo (ss. X-XI) y reciente (ss. XII-XIII). El primero se caracteriza por el empleo generalizado, en los basamentos de los muros, de mampostería en hiladas, a veces en spicatum, en crudo o alternando con gruesos lechos de argamasa de cal (fig. 1). El segundo se singulariza por utilizar la tapia de hormigón como cimiento y zócalo (fig. 14). Ambos tipos de basamentos tenían la misma finalidad: que los muros pudieran resistir eficazmente a la humedad y al agua de lluvia pues, tanto en el primero como en el segundo grupo, el resto de los alzados era de tierra 5 .

La cronología relativa de las dos clases de aparejos que hemos expuesto es indiscutible y se puede comprobar en las numerosas publicaciones, derivadas de las intervenciones arqueológicas realizadas en la ciudad de Murcia, que hemos recogido en la bibliografía adjunta; el tipo edilicio correspondiente a la fase antigua siempre aparece en niveles más profundos que el reciente $\mathrm{y}$, con mucha frecuencia, incluso el segundo sustituye al primero en el recrecimiento o refacción de un mismo muro (fig. 1), especialmente en las medianerías ${ }^{6}$.

Resulta, sin embargo, más complicado ofrecer cronologías absolutas precisas de la mayor parte de los restos examinados. En este sentido, constituye una excepción valiosa una serie de edificios estatales bien fechados en época mardanîší (1147-1171) y hudí (1228-1238), por lo que los examinaremos en apartado propio. En general, las dataciones absolutas están basadas en el registro estratigrá-

\footnotetext{
${ }^{5}$ En la ciudad de Murcia se ha comprobado que a lo largo de todo el período andalusí existieron construcciones de tierra sin basamento de mampostería u hormigón. No parece posible en la actualidad establecer distinciones cronológicas en este tipo de obra, sin duda muy humilde, con la excepción de algunos casos tardíos en los que hay refuerzos de ladrillo en las jambas y esquinas. En ocasiones, hallamos la obra de tierra completamente desaparecida y reemplazada por fábricas de mampostería, ladrillo o incluso sillarejos reutilizados, dispuestas en bataches.

${ }^{6}$ La dificultad de demoler las medianerías y extraer la piedra de sus cimentaciones explica que sea en estos lugares donde mejor se han conservado los muros de mampostería de la fase antigua. Por el contrario, dentro de cada parcela todo propietario podía derribar sus muros y recuperar los materiales empleados en cimientos y zócalos.
}

fico y en las fechas que proporcionan los materiales contenidos en los niveles de construcción, utilización, destrucción o abandono asociados a la arquitectura. Los restos de objetos de vidrio, metal y hueso no ofrecen precisiones cronológicas dado el estado actual de la investigación sobre este tipo de materiales, por lo que las referencias cronológicas proceden, básicamente, de las cerámicas y, excepcionalmente, de fragmentos de yeserías.

En las memorias e informes arqueológicos publicados encontraremos los argumentos, más o menos detallados, que se vienen dando a la hora de fechar estas fábricas a partir de los datos que aportan las cerámicas que se le asocian; no es objetivo del presente trabajo profundizar en cuestiones estrictamente ceramológicas, aunque remitimos a los estudios sobre estas producciones que desde los años 80 se han venido llevando a cabo en Murcia, la mayoría de ellos efectuados por nosotros en paralelo a las excavaciones arqueológicas que veníamos realizando en la ciudad de Murcia y en el despoblado de Siyāsa ${ }^{7}$. No obstante, podemos afirmar que, en términos generales, el aparejo de la fase antigua aparece asociado a un fósil director característico como es la cerámica decorada en «verde y manganeso», que en el Sureste se viene considerando exclusiva de los periodos califal y taifa. El aparejo de la fase más reciente tiene un claro límite ante quem, marcado por los niveles de destrucción y abandono relacionados con la conquista castellana de mediados del siglo XIII, mientras que su aparición es más difícil de datar. En algunos casos, como en la casa que denominamos A, de calle Platería 14, se ha podido asociar a época almorávide, tanto por la presencia de fragmentos de yesería como por el registro cerámico ${ }^{8}$. No obstante, con las producciones alfareras de época almorávide acontece algo similar a lo que sucede para el período taifa: la escasez de conjuntos cerrados y bien fechados en esta época hace difícil su caracterización precisa. Por otra parte, tampoco existe un fósil director claro para este periodo, por lo que normalmente los conjuntos atribuibles al mismo se identifican, permítasenos la simplificación, por la desaparición del fósil director de los siglos X-XI, que es la decoración en «verde y manganeso», y por la ausencia de los que caracterizan a la época almohade (esgrafiado sobre manganeso, candiles de pellizco y pie alto, etc.).

Basamentos con tapial de hormigón no parecen haberse empleado en época califal, puesto que ni en Madînat

\footnotetext{
7 Sin intención de ser exhaustivos, véanse Navarro, 1986a; id., 1986b; id., 1990b; id., 1991b; Navarro y Jiménez, 1995d.

${ }^{8}$ Jiménez y Navarro, 1997, pp. 29 y 30.
} 
al-Zahrâ' ni en los arrabales cordobeses hay muros con ese aparejo; estos últimos debieron de despoblarse a lo largo de la primera mitad del siglo XI con motivo de los desórdenes ocasionados por la caída del califato (fitna). Avanzando en dicha centuria, las viviendas exhumadas en Vascos (Toledo), abandonadas entre los años 1080 y 1085, tampoco presentan tapiales de hormigón en sus zócalos.

Son muy pocos los ejemplos fechados sin ningún tipo de dudas que nos puedan servir para ilustrar este cambio y en función de ellos parece que podría coincidir aproximadamente con el cambio de siglo. Así, el muro perimetral del Qasr al-Hayar, la alcazaba almorávide de Marraqués atribuida a Yûsuf Ibn Tâsufin (hacia 1070)9 contaba con un basamento compuesto por dos forros de mampostería con un relleno de tierra entre ambos, lo que sumaba un espesor total de $3 \mathrm{~m}$, el resto del alzado era, al parecer, de tierra ${ }^{10}$. En las obras que de manera indudable se pueden atribuir a su hijo 'Alî (1106-1143), sin embargo, el aparejo murario ya ha variado: para la ampliación de la Qarawiyyîn de Fez se empleó el tapial de argamasa en los muros de carga, mientras que pilares, arcos, jambas y tabiques se hicieron de ladrillo ${ }^{11}$; en la fortaleza de Tâsgîmût, destruida y abandonada no más allá de 1132 y construida muy pocos años antes, la mampostería regularizada se empleó en la parte inferior de la muralla, en las torres cuadrangulares y en las puertas, mientras que los alzados de los lienzos son de tapial de $\operatorname{argamasa}^{12}$; las residencias áulicas edificadas por 'Alî Ibn Yûsuf al sur del Qasr al-Hayar, que fueron amortizadas tras la conquista almohade al erigirse la primera Qutubiyya, contaban con muros de tapial de argamasa con jambas y umbrales de ladrillo ${ }^{13}$. Todo ello coincide con las observaciones que hemos podido realizar en Murcia, que apuntan a que el cambio de fábrica en las cimentaciones y zócalos debió de producirse, aproximadamente, en el último cuarto del siglo XI o a principios del XII; seguramente, dicho cambio no se produjo de manera repentina sino que debió de responder a un proceso, más o menos prolongado en el tiempo, cuyas fechas y extensión sólo se podrán precisar cuando contemos con más ejemplos bien datados.

A continuación trataremos de definir detalladamente las características de la arquitectura de los dos grupos señalados.

\footnotetext{
${ }^{9}$ Ibn 'Idârî, 1963, p. 40; Al-Hulal al-Mawsiyya, p. 37.

${ }^{10}$ Meunié, Terrasse y Deverdun, 1952, pp. 11-26.

${ }^{11}$ Terrasse, 1968, p. 23.

${ }^{12}$ Acién y Cressier, 2009, pp. 183-186

${ }^{13}$ Meunié, Terrasse y Deverdun, 1952, p. 27.
}

\section{FASE ANTIGUA (SS. X-XI)}

Como ya adelantamos, esta fase está esencialmente estudiada a partir de ejemplos domésticos, lo que obliga lógicamente a tomar precauciones a la hora de extrapolar conclusiones a otros tipos arquitectónicos que funcionalmente son muy diferentes, por ejemplo las fortificaciones.

\subsection{Descripción}

Los aparejos de este periodo se caracterizan por la presencia generalizada de la fábrica de mampostería, que en la mayoría de los casos queda reducida a la cimentación y al zócalo, pues el resto del alzado era de tapial de tierra o de adobe. Tanto los muros de carga como los que compartimentaban las crujías tienen un basamento compuesto por cinco o seis mampuestas o hiladas, ocasionalmente dispuestas en espiga y/o alternando con gruesos lechos de mortero de cal (figs. 1, 3 y 8). Según Font e Hidalgo, este tipo de zócalo estaría también encofrado por lo que denominan a este aparejo «tapia de piedras con hormigón de cal ${ }^{14}$. El basamento aparece enterrado en su mayor parte (fig. 9), conformando una cimentación sobre la que se levantan los alzados ya descritos. Dada la fragilidad de estas obras de tierra y su rápido deterioro es difícil en ocasiones diferenciar cuándo se trata de adobes tomados con barro o cuándo de un tapial, máxime en los casos en los que el muro original ha sido reparado con obras de mampostería o ladrillo. La parte superior del mencionado basamento de piedra solía estar por encima del nivel de suelo conformando un elemental zócalo. En efecto, esta obra de mampostería suele tener una altura total en torno a los $60 \mathrm{~cm}$, de los que cinco sextas partes serían cimiento pues sólo emergían sobre el pavimento original unos 10-15

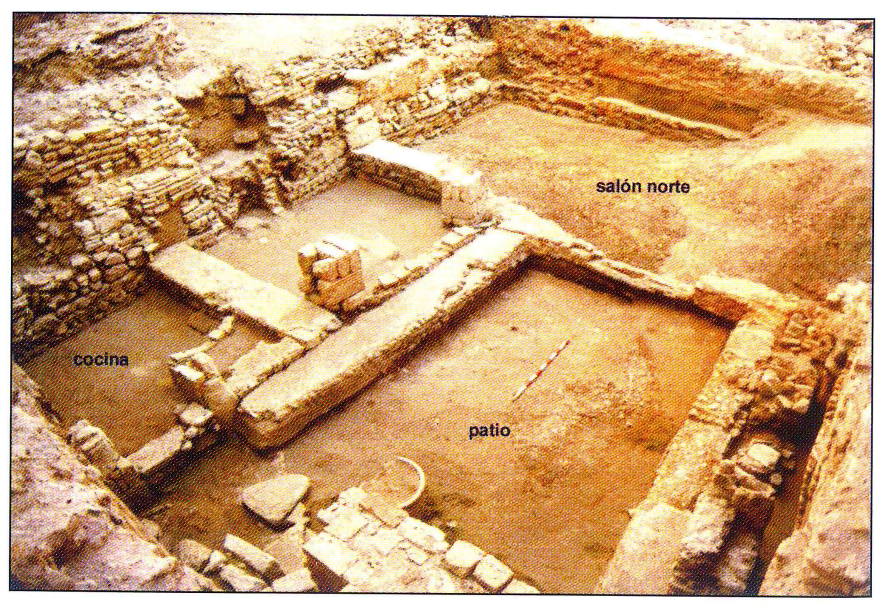

Fig. 2. Casa $\mathrm{n}^{\circ} 1$ de calle San Pedro de Murcia (ss. $x-\mathrm{xl}$ )

${ }^{14}$ Font e Hidalgo, 2009, pp. 68-71. 


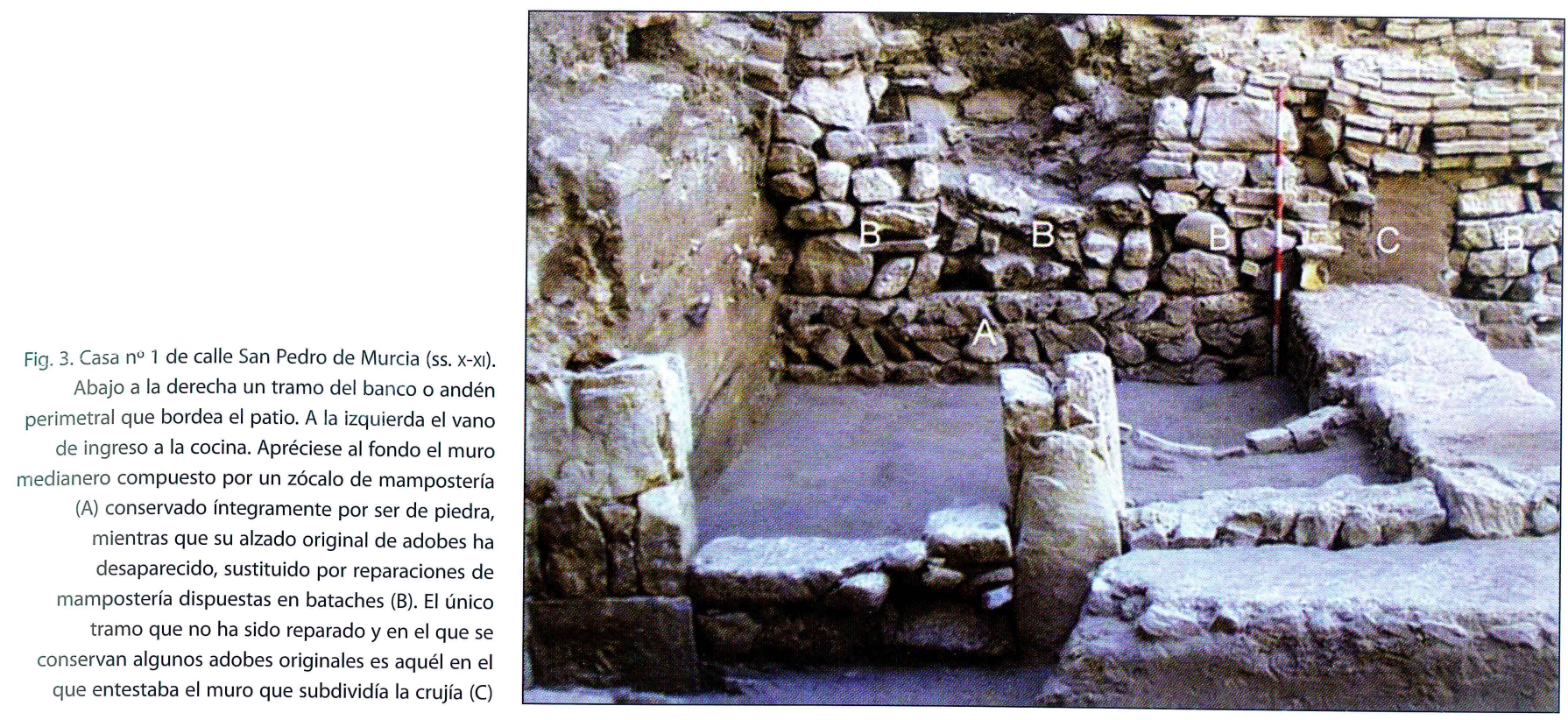

cm (fig. 9). De esta manera quedaba protegida la parte inferior del muro de tierra de la acción del agua de lluvia y de la humedad en general. El ancho de los muros de carga oscila entre 50 y $60 \mathrm{~cm}$. Los vanos, y ocasionalmente las esquinas, presentan jambas hechas con sillares de arenisca blanca, dispuestos a soga y tizón, en los que se tallan las mochetas (fig. 3). Los zócalos y los pavimentos de los salones principales estaban frecuentemente enlucidos con estuco pintado de rojo (fig. 18).

En diversas ocasiones hemos comprobado que estas cimentaciones no se hacían excavando una zanja en la tierra, sino que se levantaban sobre un suelo provisional de trabajo para a continuación elevarlo, mediante aportes de tierra y/o arena, hasta una altura de 40 ó $50 \mathrm{~cm}$, cota a la que se disponían los pavimentos definitivos. Las razones que nos permiten afirmar que el proceso constructivo era el expuesto, son las siguientes: primero, las mamposterías están perfectamente aplomadas, lo que por otra parte es normal si efectivamente se trata de tapiales; segundo, la ausencia de fosas de cimentación flanqueando los basamentos; tercero, la presencia, a la altura de la cota inferior de dichos cimientos, de suelos de trabajo, conformados por restos de la talla de los sillares de calcarenita y fosas alargadas y poco profundas en las que al parecer se amasaba el mortero de cal, y cuarto, la existencia de ciertos enlucidos preparatorios que descienden por debajo de las cotas de los suelos definitivos.

Sobre la cerámica constructiva de los niveles andalusíes de la Murcia de los siglos X y XI tenemos una información muy desigual debido a que ladrillos y baldosas suelen hallarse «in situ», siempre que no hayan sido expoliados o convertidos en escombros, mientras que las tejas aparecen en posición secundaria formando parte de

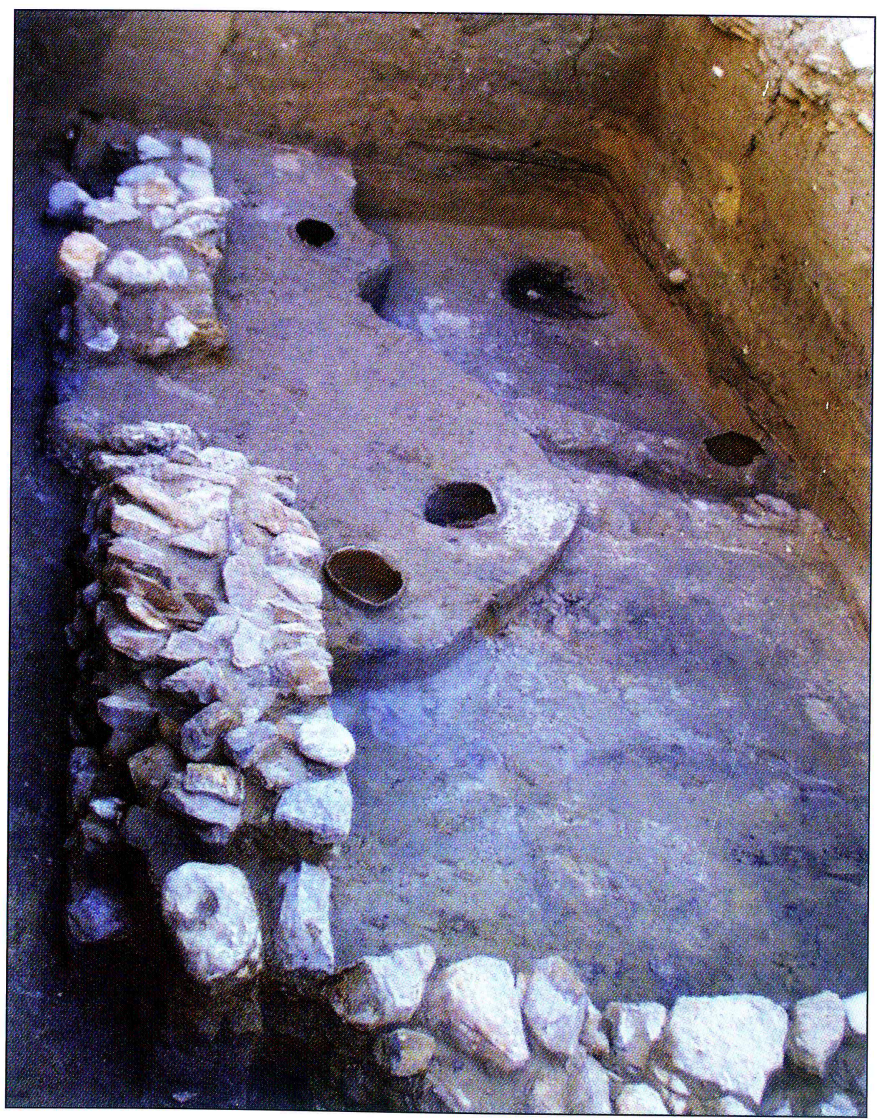

Fig. 4. Casa $n^{\circ} 2$ de calle San Pedro de Murcia (ss. IX-x). Muro con cimiento y zócalo de mampostería tomada con barro. Los restos de su alzado de tierra se pueden apreciar en el ángulo superior izquierdo de la foto 


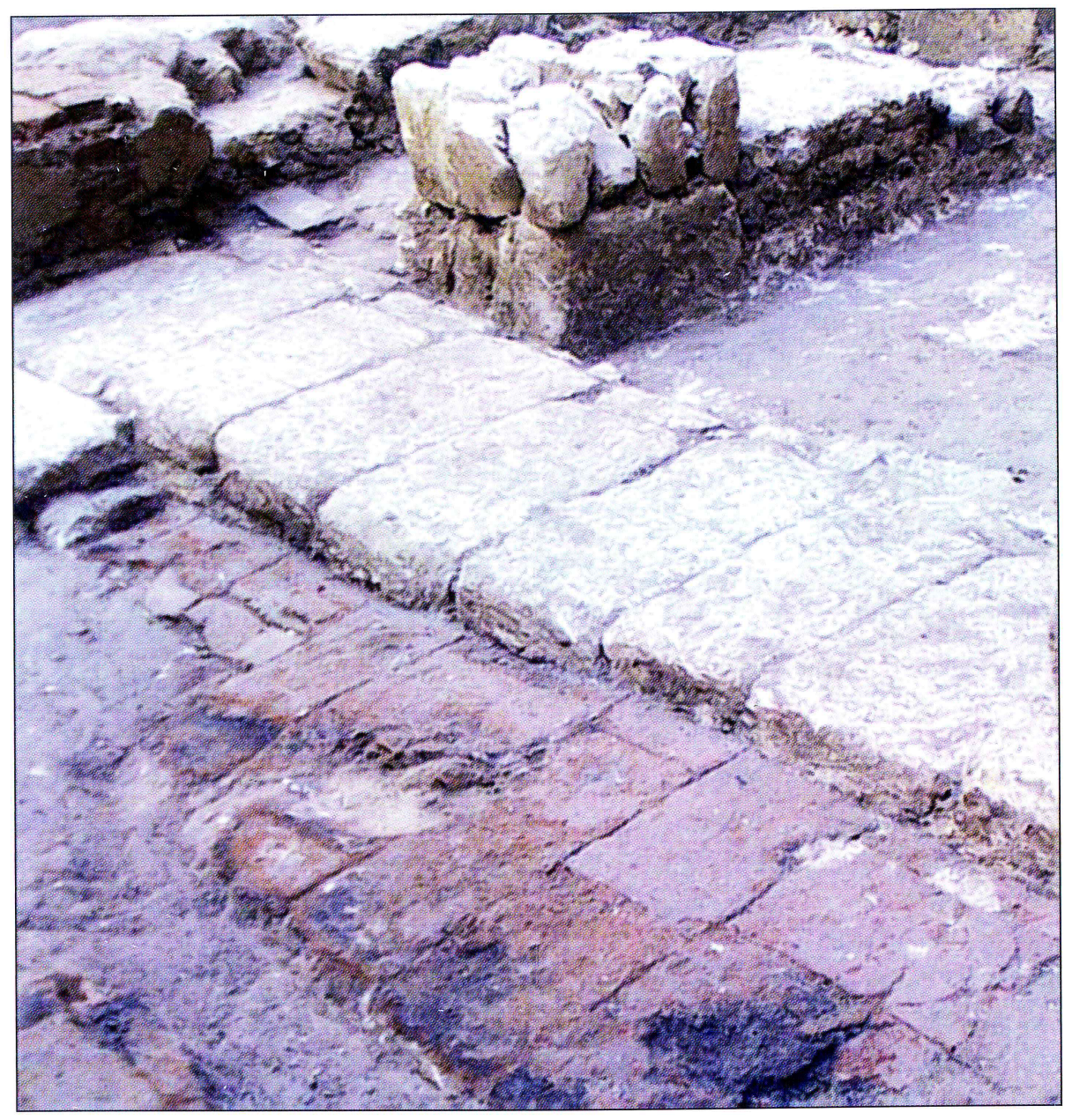

Fig. 5. Casa de calle Organistas de Murcia (ss. X-XI). Detalle del pavimento del andén a base de losas de calcoarenita y de la parte central del patio compuesto por baldosas cerámicas los estratos de abandono y/o demolición de los edificios, por lo que frecuentemente no se recogen, lo que explica por qué el estudio de la teja se encuentra ausente en la mayoría de las memorias e informes de las excavaciones que se han realizado en Murcia.

El ladrillo apenas se utilizaba y sólo lo hemos localizado en una casa situada en la calle San Pedro de Murcia, en un muro de la crujía sur del que únicamente conocemos el extremo que entesta contra el que cierra el patio por ese lado. Está formado por ladrillos grandes y relativamente aplastados de $30^{\prime} 5 \times 16 \times 42 \mathrm{~cm}$. Este mismo panorama lo encontramos en los arrabales cordobeses, en donde el empleo del ladrillo es prácticamente anecdótico, mientras que en Madînat al-Zahrầ sólo se utiliza a modo de decoración en alfices y dovelas de algunos arcos, en reparaciones puntuales, bóvedas de hornos e hipocaustos de baños ${ }^{15}$.

Sólo dos ejemplos documentan el uso de los pavimentos cerámicos en Murcia. El primero lo hallamos en el

${ }^{15}$ Vallejo, 2010, p. 319. patio de acceso a la casa de calle Organistas, cuyo andén perimetral delimita un espacio central deprimido solado con losas de cerámica rectangulares (fig. 5). El segundo se localiza en la vivienda de calle Zarandona, en la habitación central que hay en su crujía occidental; se trata de un espacio abierto al patio a modo de cenador, cuyas baldosas aparecen asentadas sobre un preparado de argamasa de cal. En ambos casos, la arcilla de las baldosas nada tenía que ver con la utilizada para los ladrillos, pues se trata de una pasta rosácea, con un desgrasante muy grueso y abundante, similar a la que se empleaba para la fabricación de los grandes recipientes cerámicos como los alcadafes. Este tipo de solería es frecuente en la arquitectura cordobesa califal, especialmente en los palacios de Madînat al-Zahrâ ${ }^{16}$, pero

\footnotetext{
${ }^{16}$ Se trata de losas en forma de ladrillo $(34 \times 21 \mathrm{~cm})$ y de baldosones $(42 \mathrm{~cm}$ de lado). El empleo más importante se dio en la residencia íntima de 'Abd alRahmân III, la Dâr al-Mulk. Todos se confeccionan «con arcillas muy rojas, mezcladas con una proporción importante de silice gruesa y pequeños fragmentos de mica muy característicos. En bastantes casos la cochura es muy deficiente, probablemente por el grosor de las piezas, presentando en su interior un núcleo de color grisáceo» (Vallejo, 2010, p. 348). Esta misma factura presentan las losas de barro murcianas.
} 


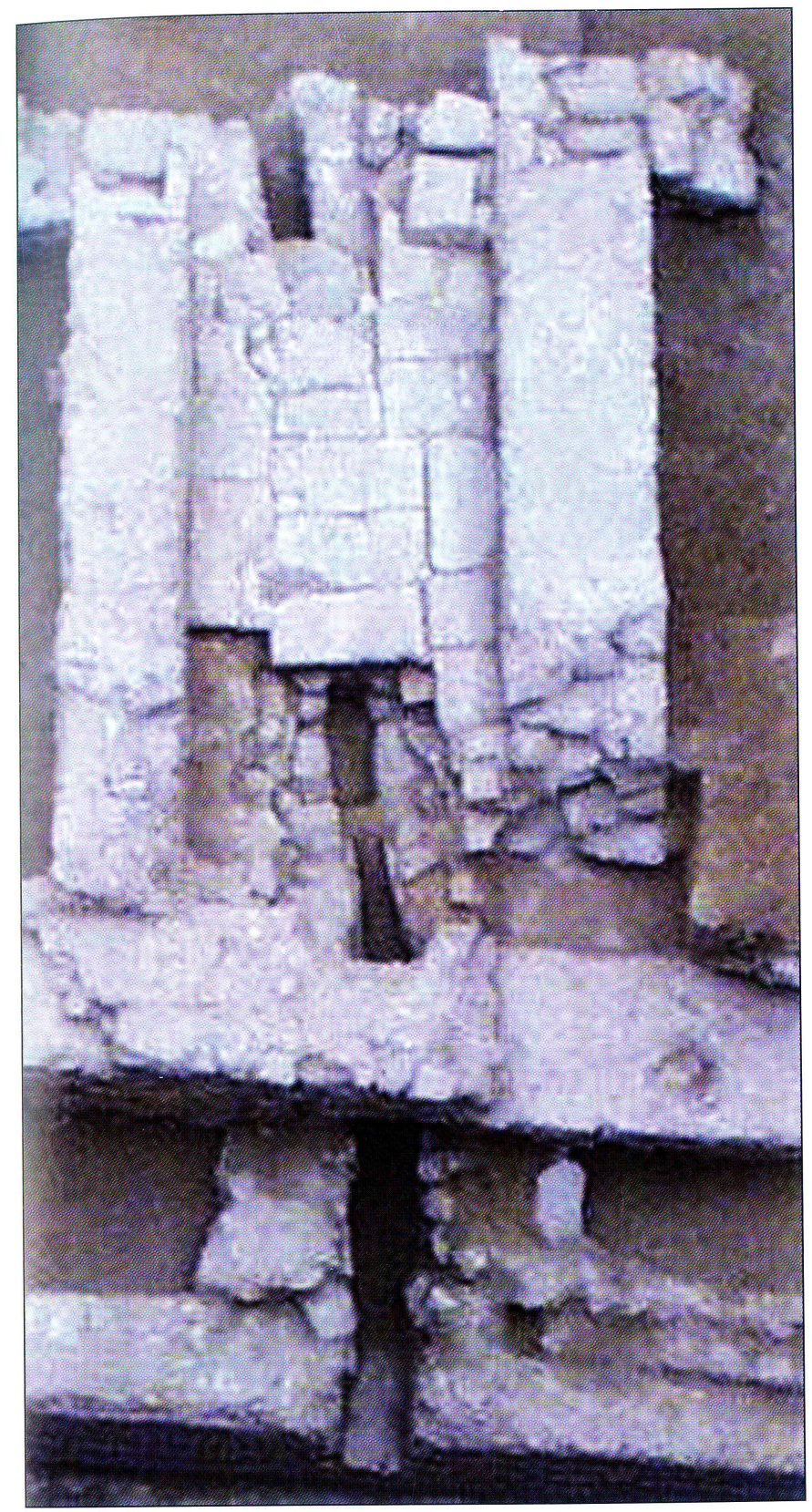

Fig. 6. Casa de calle Victorio de Murcia (ss. x-xI). Letrina con pavimento de losas de piedra

también en las numerosas casas exhumadas en los arrabales, donde se ha localizado en salas, pórticos e incluso letrinas ${ }^{17}$. Aunque no podemos descartar completamente que la escasez de estos pavimentos en Murcia pueda deberse a un simple fenómeno de expolio y reutilización, nos inclinamos por considerarla como un indicio del inferior desarrollo del artesanado especializado en las

${ }^{17}$ Castro, 2005, pp. 135-155; Fuertes, 2007; Camacho, 2008, p. 223 y láminas 4 y 5; id., 2010, láminas 5 y 6; Aparicio, 1992, pp. 220 y 222; id., 2004, pp. 1.129 y 1.132; id., 2008b, pp. 245 y 246; Aparicio, 2010, pp. 186 y 195 y Lámina 14; Aparicio y Riquelme, 2008, p. 99. localidades periféricas; habrá que esperar a finales del siglo XII para ver aquí abundantes solerías de cerámica.

Los patios solían pavimentarse con losas de calcarenita, tanto los andenes como los espacios centrales deprimidos, obviamente siempre que estos últimos no fueran áreas ajardinadas. La solución mixta de andenes de piedra y parte central de baldosas de cerámica ya la vimos en la casa de calle Organistas (fig. 5). Ocasionalmente los andenes aparecen solados sencillamente con mortero de cal alisado (figs. 2 y 3) aunque, hasta donde hoy conocemos, esta solución era más infrecuente ${ }^{18}$. También hemos comprobado que los suelos de losas de piedra se extendían, en ciertos casos, a las letrinas (fig. 6), a los zaguanes y a los pasillos de comunicación entre patios. Este uso coincide con el que se ha podido documentar en las viviendas de los arrabales cordobeses, en donde los encontramos principalmente, en zonas de paso como zaguanes, establos, patios, letrinas y, excepcionalmente, en dos establos y en una alcoba ${ }^{19}$. En Madînat al-Zahrâ' la calcarenita se utilizó en los extensos espacios de circulación al aire libre, como los andenes centrales y perimetrales de los jardines Alto y Bajo, de la mezquita aljama, y los que rodean la plaza frontera al salón basilical superior; también se empleó en los espacios de circulación cubiertos, así como en los patios y andenes de diversos edificios. En las estancias interiores el uso se limitó a los espacios de ingreso y comunicación, habitaciones menores o de servicio y algunas letrinas ${ }^{20}$. Al igual que en Murcia y en los arrabales de Córdoba, en los andenes de los patios las losas rectangulares se colocan en tabla, perpendiculares a cada uno de los muros perimetrales a los que se adosan, a una altura media de 15 ó $20 \mathrm{~cm}$ sobre el rebaje central del patio, dimensión que viene a ser el grueso de las losas.

Los salones, sin embargo, contaban con suelos de argamasa sobre preparados de zahorra o ripios. Frecuentemente durante su alisado final se les aplicaba una fina película de almagra, siendo la solución más habitual tanto en estas salas principales como en otras de menor rango.

La escasa altura de los zócalos de mampostería, transcurrido un tiempo, facilitó el rápido deterioro de los muros de tierra, por lo que fue necesario repararlos. Para ello sólo cabían dos posibilidades: utilizar forros de ladrillo o mampostería, o bien rehacerlos casi en su totalidad. Esta última solución no es infrecuente y la manera en que se solía llevar a cabo era apuntalando las vigas del forjado del

${ }^{18}$ Llama la atención que los andenes del patio de crucero del palacio de Onda (s. $\mathrm{XI})$ estén desprovistos de cualquier tipo de solería que no sea el simple mortero alisado (Navarro y Estall, 2010).

${ }^{19}$ Camacho, 2008, p. 223.

${ }^{20}$ Vallejo, 2010, p. 344. 


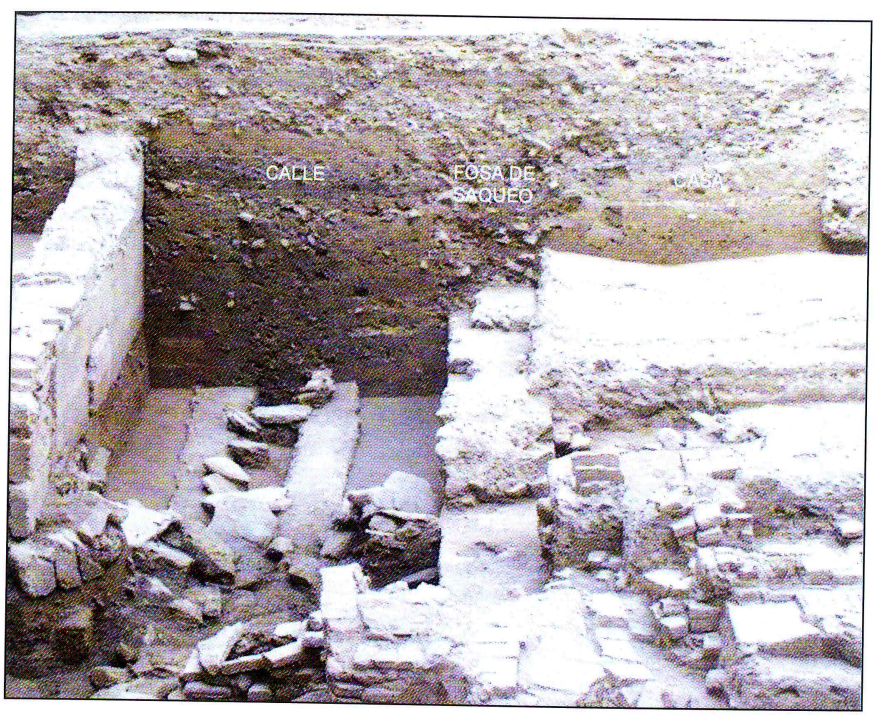

Fig. 7. Casa de calle Victorio de Murcia. Obsérvese el saqueo del muro de mampostería situado en el centro de la imagen, destruido por debajo del nivel de suelo de la habitación (a la derecha) y que ocasionó la fosa que se aprecia en el perfil estratigráfico

techo, para no tener que desmontarlo, y reconstruir el muro progresivamente mediante estrechos tramos, a modo de bataches, cuya longitud no solía exceder los $80 \mathrm{~cm}$ (figs. 3,8 y 9).

La mayor parte de las estructuras que emplearon parcial o totalmente la piedra fueron objeto de saqueo ya en época islámica, pues se trata de un material susceptible de ser reutilizado ${ }^{21}$. Este proceder debió de ser especialmente intenso en una ciudad como Murcia, cuyo emplazamiento en una depresión aluvial convertía la piedra en un material cotizado (fig. 7). En realidad, ninguna de estas viviendas antiguas que venimos describiendo llegó en su estado original a época tardoislámica. Algunas de ellas fueron rehechas varias veces cambiando por completo el aspecto original y permanecieron en uso hasta los siglos XIV o XV, por ejemplo las excavadas en San Pedro y Zarandona, mientras que otras fueron demolidas en los siglos XII o XIII y sobre su solar se levantó otra nueva que nada tenía que ver con la anterior salvo las paredes perimetrales que, al estar compartidas con el vecino como medianeras, tenían que ser lógicamente respetadas. Conviene recordar que, a diferencia de lo que sucede en el mundo romano, donde esto sólo es posible si el vecino da permiso, la jurispruden-

\footnotetext{
${ }^{21}$ Noticias sobre el alto valor de los materiales constructivos procedentes de la demolición de viviendas nos las proporciona el Rawd al-Qirtas, cuando se describe la ampliación de la mezquita al-Qarawiyin de Fez en el año 1134: "Cuando acabó de comprar las casas que quería y que le convenían, se dio a demolerlas y vendió sus escombros, con cuyo precio reunió lo que le habian costado las casas; le quedó gratis el solar...» (Ibn Abî Zar', 1964, p. 117).
}

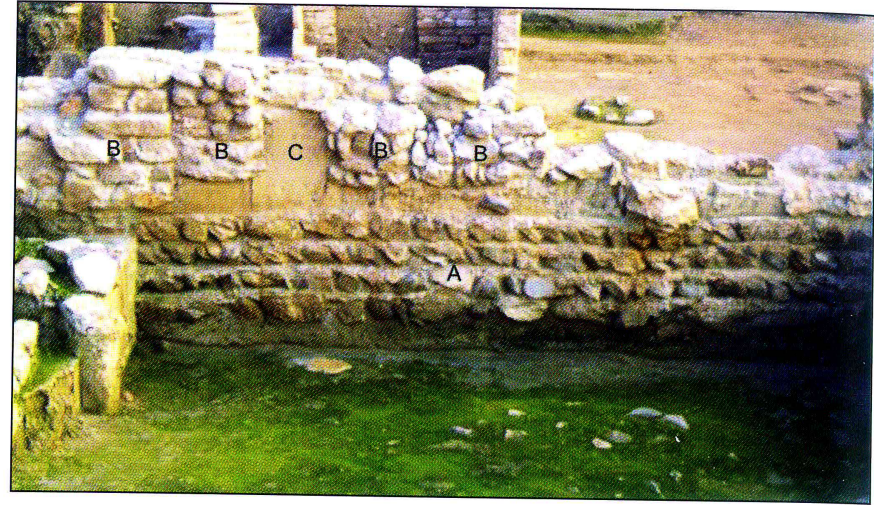

Fig. 8. Casa de plaza Belluga de Murcia. Muro medianero entre dos viviendas andalusíes. Obsérvese el cimiento de mampostería de la obra original (A) y las reparaciones realizadas con bataches de mampuestos (B) de casi todo el antiguo alzado de tierra (C)

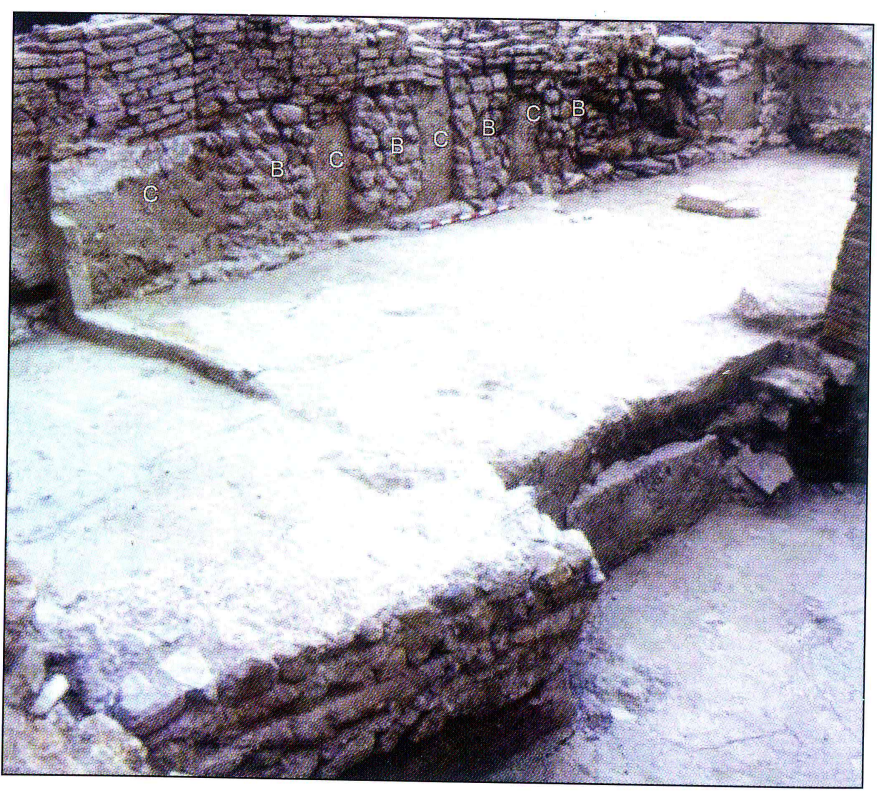

Fig. 9. Casa de plaza Belluga de Murcia (ss. x-xI). Salón norte. Obsérvese en la medianera del fondo las reparaciones realizadas con sucesivos bataches de mampostería (B) que dejan entre si angostos tramos del alzado original de tierra (C). El basamento de mampostería es casi todo cimentación, pues sólo su hilada de piedras superior está por encima de la cota marcada por el suelo original

cia islámica prescribe que, si no hay peligro de ruina, la nueva construcción puede apoyar sus vigas en la pared colindante, lo que de hecho da lugar en el urbanismo islámico a la máxima adyacencia entre las propiedades por la servidumbres de muros medianeros ${ }^{22}$. Cuando las casas eran objeto de pequeñas reformas también se reutilizaban algunos de sus materiales, especialmente los pavimentos de piedra en las frecuentes sobreelevaciones de suelos. Pero

22 Brunschvig, 1947, p. 137; Van Staevel, 1995, p. 58; García-Bellido, 1999, p. 991. 
cuando los inmuebles eran totalmente demolidos, la intensidad del saqueo y de la recuperación de materiales podía llegar a afectar incluso a sus cimientos de mampostería, dejando apenas rastro de su existencia ${ }^{23}$. Por esta razón tenemos con frecuencia una información muy parcial y fragmentaria de las viviendas de esta cronología, lo que da lugar a ciertas impresiones infundadas como las que defienden una escasa presencia de edificios en la Murcia anterior al siglo $\mathrm{XI}^{24}$.

\subsection{Paralelos y cronología}

La mayor parte de los edificios de esta etapa excavados en la ciudad de Murcia han sido identificados como obras de época califal o taifa por su asociación con un tipo de producción cerámica, el «verde y manganeso», que responde a esa cronología. La casa de Zarandona mostraba, tras el momento fundacional, una segunda fase fechable en el siglo XI, por lo que nos inclinamos por suponer que fue fundada en el siglo X o, como muy tarde, a comienzos del $\mathrm{XI}^{25}$; lo mismo parece haber sucedido en la de San Pedro ${ }^{26}$. Apenas tenemos datos para fechar estratigráficamente las viviendas $\mathrm{B}$ y C de Platería debido a que no se conservó pavimento alguno y a que los muros habían sido sometidos a un saqueo casi completo $^{27}$; lo mismo cabe decir de la hallada en Puxmarina ${ }^{28}$. De la casa de Frenería, que apareció en un estado de conservación relativamente bueno, se publicó una planta bastante completa pero no materiales asociados, por lo que sus propios excavadores proponen una cronología imprecisa entre los siglos X-XI ${ }^{29}$. Una de las mejor fechadas es la residencia polinuclear de calle Fuensanta gracias a los abundantes hallazgos que proporcionaron los niveles de fundación; fue construida en la segunda mitad del siglo X sobre un edificio de la primera mitad de ese mismo siglo ${ }^{30}$. También en el siglo X se fechó la primera fase de otra, muy incompleta, hallada en el $n^{\circ}$ 27 de calle San Nicolás ${ }^{31}$. En los siglos X-XI se sitúa la fase más antigua del llamado Espacio 2, en el Garaje Villar ${ }^{32}$ y algunos restos murarios de calle Selgas ${ }^{33}$. De otros no se nos facilita información cronológica, como sucede con la

${ }^{23}$ Este fenómeno lo podemos ver en la casa b de calle Platería (Jiménez y Navarro, 1997, p. 33).

${ }^{24}$ Ramírez y Martínez, 1996.

${ }^{25}$ Jiménez y Navarro, 2002b.

${ }^{26}$ Jiménez, Navarro y Sánchez, 2006.

${ }^{27}$ Jiménez y Navarro, 1997, pp. 33-39.

${ }^{28}$ Jiménez, Navarro y Thiriot, 2005.

${ }^{29}$ Fernández y López, 1993.

${ }^{30}$ Bernabé y López, 1993, pp. 39-48.

${ }^{31}$ Bernal y Calabuig, 1995.

${ }^{32}$ Manzano, 1995, p. 362.

${ }^{33}$ López Martínez, 1993. vivienda de Polo de Medina ${ }^{34}$. Al siglo XI se le vienen atribuyendo las casas de Platería $31-35^{35}$ y las de plaza $\mathrm{Balsas}^{36}$. El estudio del ejemplar polinuclear exhumado en la calle Organistas está actualmente en prensa ${ }^{37}$; su momento de construcción parece que se puede situar en el siglo $\mathrm{x}$ y los niveles que lo amortizan, en la centuria siguiente. No tenemos precisiones cronológicas seguras para las viviendas de Victorio y Santa Eulalia, pues están aún inéditas y en proceso de estudio.

Fuera de la ciudad de Murcia, pero en contextos plenamente tudmiríes, está comprobada la difusión del aparejo que nos viene ocupando, por ejemplo en el Castellar de Elche (Alicante), cuyo abandono se data entre la segunda mitad del siglo x y la primera del X ${ }^{38}$. Más precisiones proporciona la Rábita de Guardamar ${ }^{39}$, cuya fase institucional está bien fechada por una lápida del año 944 (fig. 10); gracias a este dato conocemos también la cronología relativa de sus otras fases:

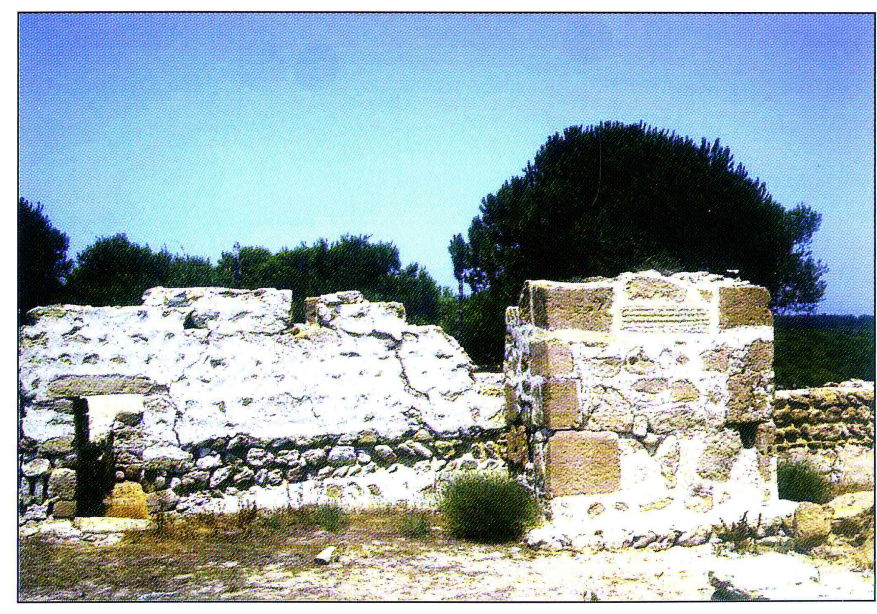

Fig. 10. Rábita califal de Guardamar (Alicante). En primer término, la fachada exterior del mihrab con la lápida fundacional que fecha el oratorio en el $944 \mathrm{~d}$. C.

$1^{\text {a }}$ Fase, Etapa I. Se le puede denominar arcaica y se fecha entre comienzos del siglo $\mathrm{x}$ y el año 944. Los muros son de mampostería tomada con barro y enlucidos con el mismo material. Los basamentos están constituidos por grandes mampuestos dispuestos sin orden; aparecen también jambas formadas por grandes losas de piedra rectangulares.

\footnotetext{
${ }^{34}$ Andreu, 1997.

${ }^{35}$ Ramírez y Martínez, 1999.

${ }^{36}$ Robles y Navarro, 2002.

${ }^{37}$ Navarro y Jiménez, en prensa.

${ }^{38}$ Gutiérrez, Martí y Menéndez, 2010, pp. 33 y 34.

${ }^{39}$ La rábita constituye una fuente de información de primer orden acerca del momento en que estuvo en uso, concretamente todo el siglo X (Azuar, 1989; id., 2004a; Azuar et al., 1988/90).
} 
$1^{\text {a }}$ Fase, Etapa II. Es la institucional y corresponde a los edificios que portan la lápida de fundación en el año 944. A diferencia del resto, los muros de estas construcciones están levantados con mampostería tomada con mortero de cal y ocasionalmente enlucidos con el mismo material. Excepcionalmente el alzado de la mezquita principal es en su totalidad una obra de mampostería, por lo que se aleja de las prácticas más habituales en las que un zócalo de esas características era la base de un alzado de tierra. Otro rasgo fundamental en estas fábricas es la consolidación del aparejo en opus spicatum, que por diferentes paralelos Azuar considera como propio de los siglos X-XI.

$2^{\text {a }}$ Fase. Segunda mitad del siglo X. Se caracteriza por una degradación del aparejo en opus spicatum, el cual mantendrá la horizontalidad de sus hiladas pero dispuesto de manera más irregular.

$3^{a}$ Fase. Fines del siglo X y principios del XI. Caracterizada por la generalización de la tapia de tierra sobre basamentos de mampostería. A juicio de Azuar, este momento es muy interesante pues permite documentar precedentes de los tapiales de argamasa de los siglos XII-XIII y posteriores ${ }^{40}$.

El aparejo descrito para las casas murcianas se asociaría, por tanto, al periodo «institucional» de la Rábita, que está bien datado a mediados del siglo X. No creemos que se pueda remontar a época emiral, al menos por lo que se refiere a la ciudad de Murcia, aunque en este caso apenas tenemos información y conviene que examinemos algunos paralelos.

Entre las viviendas emirales y califales exhumadas en Córdoba existe una serie de diferencias interesantes que podrían extrapolarse, al menos parte de ellas, a otras ciudades de al-Andalus. Acién y Vallejo presentan de esta manera las características de la arquitectura del siglo IX en oposición a la del X: "La mayor presencia de fábricas de mampostería construidas con calizas irregulares del secundario $e$ incluso cantos del río, frente a la utilización de las

\footnotetext{
${ }^{40}$ Como vemos, sólo en relación a la $3^{a}$ fase Azuar distingue entre basamentos de piedra y alzados de tierra, de lo que parece deducirse que en la $1^{\mathrm{a}}$ y $2^{\mathrm{a}}$ no existió tal solución mixta. Es cierto que en la fase institucional, en especial en la mezquita principal, la totalidad de sus alzados estaban construidos con mampostería en spicatum tomada con cal. Para las otras fases, y a pesar del silencio del texto de Azuar, creemos muy probable que estos muros en origen tuvieran alzados de tierra sobre zócalo de piedra que, al ser reparados totalmente con mampostería, terminaron dando la impresión de que todo el muro se hizo con piedra, siendo muy difícil apercibirse de que se trata de reparaciones. De hecho, en una de las fotos correspondientes a un muro de la segunda fase podríamos diferenciar el basamento original con piedras de mayor tamaño del resto del alzado, sobre el que se sitúa el supuesto opus incertum que para nosotros es una simple reparación (Azuar et al., 1988/90, lám. 10).
}

calcarenitas trabajadas en forma de sillares, el predominio de suelos terrizos frente a los pavimentos de pizarra, barro cocido o argamasa coloreada, la escasa especialización de las habitaciones, donde no encontramos el desarrollo de alcobas, la insuficiente estructuración del patio que no presenta andenes, y la ausencia de una red de saneamiento común, sustituida por un gran número de pozos negros, son algunos de los rasgos.... ${ }^{41}$.

Recientemente se han llevado a cabo una serie de intervenciones en el antiguo arrabal de Saqunda, en Córdoba, cuyos resultados han comenzado a publicarse en 2008 y que resultan de gran interés por varias razones, entre las que destacaremos la considerable extensión excavada $\left(22.000 \mathrm{~m}^{2}\right)$ y su ajustada delimitación temporal, entre el momento de la formación del barrio a mediados del s. VIII y el famoso «motín del arrabal» que dio lugar a su destrucción y a la deportación de sus habitantes en el año $818^{42}$. Los numerosos edificios presentan una gran homogeneidad desde el punto de vista constructivo, pues cuentan con zócalos compuestos por cantos rodados tomados con barro, dispuestos en hiladas más o menos inclinadas entre las que ocasionalmente aparecen otras de teja, conformando un aparejo similar al opus spicatum. Las piedras se disponen careadas, las de mayor tamaño en los laterales, mientras que el interior está relleno con cantos menores y ripio. El número de hiladas oscila entre 1 y 6 , aunque en ciertos casos no se puede descartar la posibilidad de que algunas hayan desaparecido. No existe evidencia de la composición de los alzados aunque, ante la ausencia de derrumbes de piedra u otro material, sus excavadores se inclinan por suponer que fueron obra de «tapial de tierra». Las jambas estaban reforzadas mediante lajas verticales o sillarejos de calcarenita, cantos de río de mayor tamaño o fragmentos constructivos romanos reutilizados.

Por consiguiente, las fábricas murcianas que venimos estudiando serían muy similares a los aparejos que Acién y Vallejo fechan en el siglo $\mathrm{X}$, mientras que la arquitectura emiral del área surestina se parece, hasta donde conocemos, a las cordobesas que acabamos de mencionar; por ejemplo, en el Tolmo de Minateda en Hellín (Albacete) se han exhumado varias casas visigodas y emirales (al parecer la ciudad se despobló en el siglo Ix) que han permitido comprobar la pervivencia de ciertas técnicas constructivas tardoantiguas después de la conquista musulmana. Los edificios presentan muros formados por hiladas de piedras irregulares tomadas con tierra y un relleno interior de

\footnotetext{
${ }^{41}$ Acién y Vallejo, 1998, p. 121).

${ }^{42}$ Casal, 2008.
} 

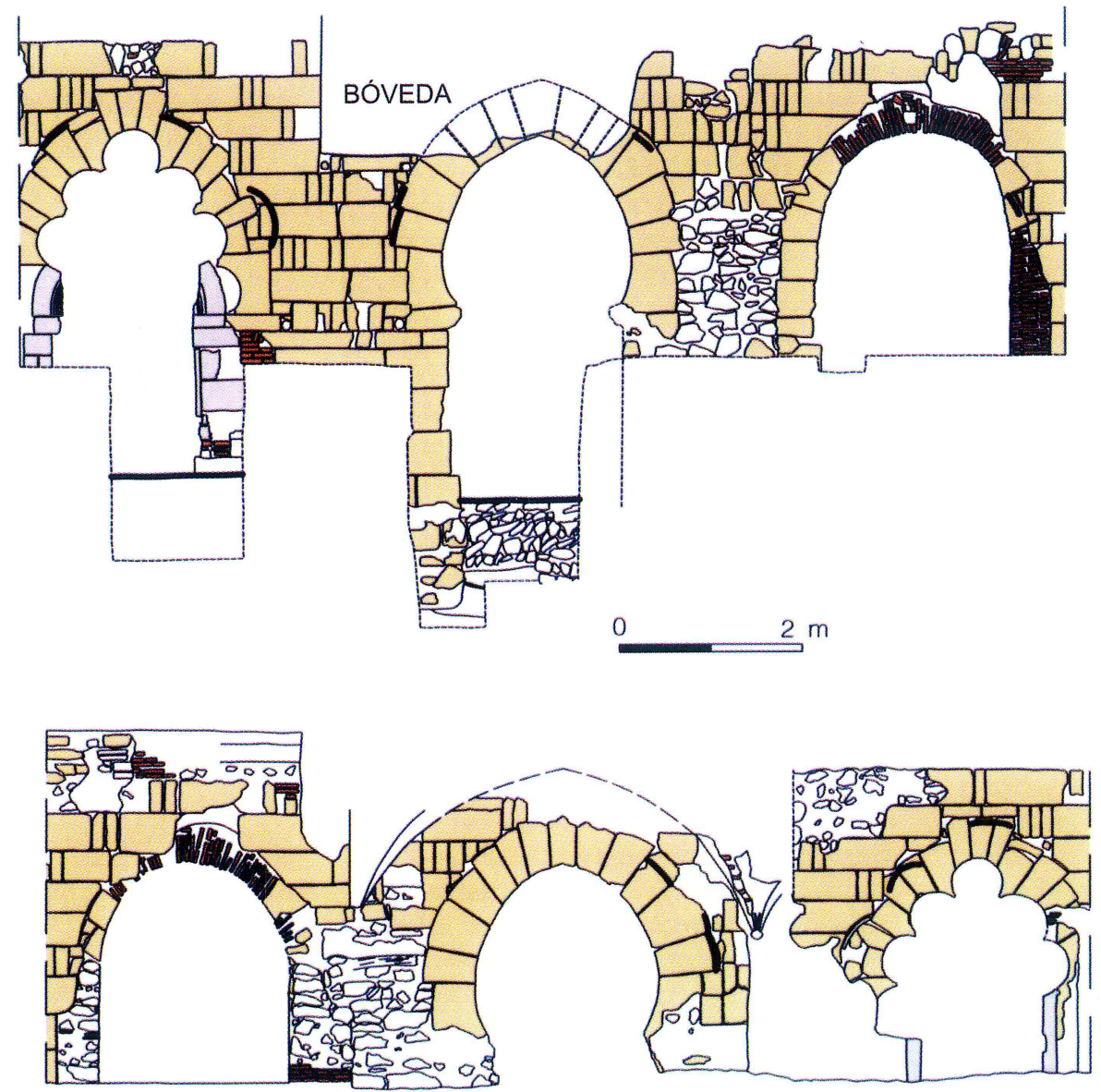

Fig. 11. Alzados de la arquería del edificio califal-taifa hallado en el convento de Nuestra Señora de las Huertas de Lorca (Martínez y Ponce, 2008)

mampuesto pequeño. Dada su escasa altura conservada, aún se ignora si se hicieron totalmente en piedra o si sobre la base de estos zócalos hubo alzados de tapial de tierra. Las jambas están constituidas por grandes bloques de piedra dispuestos verticalmente; esta misma solución de refuerzo también la vemos en las esquinas, conformando así un aparejo que recuerda al opus africanum ${ }^{43}$. Igualmente se ha visto en la ciudad de Valencia, en al menos en cinco puntos distintos, que los muros del siglo IX o comienzos del $\mathrm{X}$ presentan zócalo de piedras trabadas con barro ${ }^{44}$. Finalmente, en la rábita de Guardamar se observó que en los inmuebles anteriores a 944 no está generalizado el empleo de la argamasa de cal, a diferencia de lo que sucede en la fase siguiente.

Es posible que, también en la ciudad de Murcia, la presencia o no de gruesos lechos de mortero de cal para el asiento horizontal de cada una de las mampuestas o hiladas

\footnotetext{
${ }^{43}$ Gutiérrez, 2000, p. 163.

${ }^{44}$ Martí y Pascual, 2000, pp. 507 y 508.
}

de piedra tenga en algunos casos un valor cronológico ${ }^{45}$. Así, por ejemplo, en la excavación de calle San Pedro y en otra en calle Victorio hemos comprobado que su empleo es propio de edificios relativamente más tardíos que aquéllos en los que la mampostería está tomada con barro ${ }^{46}$, lo que también se pudo comprobar en la excavación de la calle Fuensanta ${ }^{47}$.

Conviene, no obstante, ser cautos en este sentido hasta que no se disponga de más evidencias arqueológicas; así, por ejemplo, en la actualidad se está excavando el castillo de las Paleras, en Alhama de Murcia, cuyos muros perimetrales disponían de un basamento compuesto por hiladas de mampostería en falsa espiga sobre lechos de

\footnotetext{
45 Azuar es uno de los que defienden el valor cronológico de estos aparejos cuando afirma que existe una "perduración en los contextos urbanos, hasta bien entrado el siglo $X$, de las técnicas de aparejo de mampuestos con mortero de barro, que conviven con la aparición en la segunda mitad o a fines del siglo $I X$ de los morteros de "cal» que al principio sirven para recubrir o enlucir los muros y ya en el siglo X para aparejarlos en fabricas de mortero de cal» (2009, p. 25).

${ }^{46}$ Acién y Vallejo, 1998, p. 121).

${ }^{47}$ Bernabé y López, 1993, p. 18.
} 


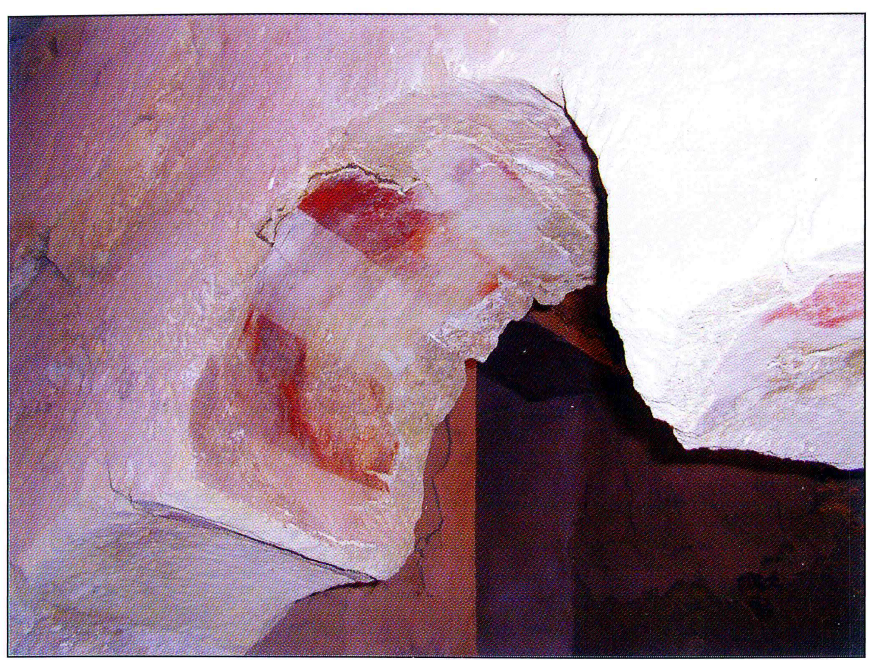

Fig. 12. Detalle del lóbulo central del arco del convento de Nuestra Señora las Huertas de Lorca, donde se observa el dovelaje fingido mediante pintura roja sobre el enlucido

argamasa de cal. Aunque el monumento está en proceso de excavación los primeros indicios apuntan, con todas las reservas, a que se trataría de una obra del siglo $\mathrm{IX}^{48}$.

La fábrica que anteriormente hemos descrito al estudiar las viviendas murcianas de la fase antigua, poco tiene que ver con la que encontramos en el yacimiento más emblemático del período califal, Madînat al-Zahrâ', en donde los muros se levantaron con sillería de calcarenita aparejada a soga y tizón, tomada con mortero de cal, que abarca el alzado completo de las estructuras ${ }^{49}$. No se deben buscar razones simbólicas o estéticas en la elección de este aparejo en la fundación califal, pues los muros estaban totalmente enlucidos ${ }^{50}$. Por consiguiente, no es sencillo hallar las causas que expliquen por qué la sillería apenas está presente en las casas de los arrabales de Córdoba, aunque es posible que sean de naturaleza económica, pues en estos ensanches urbanos la sillería suele aparecer asociada a los edificios más ricos, especialmente a las grandes almunias que fueron las primeras en establecerse en la zona antes de que se extendiera sobre ella el tejido urbano ${ }^{51}$. En este sentido, conviene señalar que en el área murciana también se ha encontrado este aparejo de sillería en el interior del convento franciscano de Nuestra Señora la Real de las Huertas; se trata de un muro de sillería a soga y tizón de 11 '35 m de longitud y 0'60 m de anchura en el que se abren tres arcos, dos de ellos conservados suficientemente para reconocer

\footnotetext{
${ }^{48}$ Información verbal transmitida por los directores de la excavación, D. José Baños y D. Juan Antonio Ramírez, a quienes quedamos muy agradecidos.

${ }^{49}$ Vallejo, 2010, pp. 295 y 296.

${ }^{50}$ Vallejo, 2010, p. 320.

${ }^{51}$ Arnold, Canto y Vallejo, 2009; Camacho, 2010.
}

que el central es de herradura apuntada y el oriental polilobulado (figs. 11 y 12). Sus descubridores los publicaron como «una obra homogénea» ${ }^{52}$ cuya cronología oscilaría «entre finales del siglo $\mathrm{X}$ y principios del XI ${ }^{53}$, identificándolo como un palacio. Nosotros nos inclinamos por creer que se trata de la fachada por la que se abría la sala de oración de una mezquita a su patio. Además, observamos una clara discontinuidad entre los sillares que conforman los arcos y el muro en el que se alojan, apreciándose que la piedra de ambas obras es diferente. Teniendo en cuenta que también resulta difícil conciliar la presencia de un arco con un perfil tan apuntado en un muro de aparejo califal, opinamos que el muro efectivamente es una obra del siglo $\mathrm{X}$ pero los arcos son una reforma, que muy posiblemente hay que situar en el siglo XI.

Si bien no es nuestra intención profundizar ahora en el tema de los materiales y técnicas constructivas empleados en fortalezas y murallas, que evidentemente tienen una serie de peculiaridades que las diferencian hasta cierto punto de la arquitectura «civil», sí queremos llamar la atención sobre un aspecto de ellas que ya hemos tratado en anteriores trabajos ${ }^{54}$; nos referimos a las obras de reparación y fortalecimiento de las murallas antiguas. De la misma manera que en los edificios de esta época que venimos examinando la fábrica dominante consiste en cimientos y zócalos de piedra, en seco o con argamasa, y alzados de tierra, sean de adobe o tapial, también en la arquitectura defensiva de ese momento se dio similar panorama técnico. Sin embargo, se ha podido comprobar que la mayoría de las fortificaciones urbanas más antiguas fueron objeto de importantes reformas en los siglos XII y XIII, momento en el que aumenta considerablemente la presión de los reinos cristianos sobre al-Andalus y se generaliza el empleo de la tapia de argamasa ${ }^{55}$. En algunos casos, las nuevas murallas se alzaron sobre el mismo trazado de las antiguas, lo que habitualmente supuso su eliminación sin dejar rastro alguno, pues solían ser de menor porte y consistencia. En otras ocasiones lo que se hacía era adosar la nueva fábrica a la de tierra preexistente que, de esta manera, servía de pared de contención para el encofrado, según hemos podido comprobar en fortalezas en las que hemos intervenido, como la del castillo de Alhama de Murcia ${ }^{56}$. Las murallas del Pla d'Almatá de

\footnotetext{
52 Ponce y Martínez, 2008, p. 195.

53 Ponce y Martínez, 2008, p. 197.

${ }^{54}$ Navarro y Jiménez, 2007b, pp. 281 y 282; Navarro y Jiménez, 2007c, pp. 75-77.

${ }_{55}$ Tan sólo a modo de ejemplo podemos citar las de Sevilla, Córdoba, Málaga y Murcia.

${ }^{56}$ Baños y Jiménez, 2005.
} 
Balaguer, fechadas entre fines del s. VIII y el s. IX, cuentan con basamento compuesto por seis hiladas de sillares sobre las que se eleva una obra de tierra; los cubos presentan una fábrica de sillería perimetral con un núcleo de arcilla muy compacta $^{57}$, aunque nosotros no descartamos que estos núcleos terrosos sean, más bien, las torres primigenias que posteriormente fueron reforzadas con un forro pétreo. Este fenómeno es el que descubrió Antonio Almagro en la fortaleza de Gormaz, en la que aún se puede apreciar que la muralla original de tierra y zócalo de mampostería fue envuelta por un forro exterior de mampostería; con el paso del tiempo la obra más antigua se deshizo, quedando solamente su basamento de piedra y la impronta de la vieja muralla en la nueva obra ${ }^{58}$. Por este motivo la cerca de mampostería que hoy vemos en Gormaz no tiene una autentica cara interna (fig. 13).

\section{Fase reciente}

Ya comentamos que a partir de una fecha imprecisa, que podríamos situar a fines del siglo XI o comienzos del XII, los basamentos de mampostería son sustituidos en la arquitectura doméstica por fábricas de tapia de argamasa (figs. 1417); lo que Graciani y Tabales definen en su clasificación cronotipológica como una tapia mejorada por la incorporación de un conglomerante de cal, que se denominaría tapia acerada o rea ${ }^{9}$. No obstante, los alzados de los muros siguen siendo de tierra.

Gracias a las excavaciones en la ciudad de Murcia y en otros puntos del Levante contamos con numerosos ejemplos así construidos, aunque no disponemos de cronologías absolutas en la mayoría de los casos, con la excepción de las edificaciones mardanîšíes (1147-1172) y hudíes (1228-1238) de las que nos ocuparemos más adelante en detalle, precisamente por estar bien fechadas. El período finaliza con la conquista del Levante peninsular por castellanos y aragoneses durante el segundo cuarto del siglo XIII, lo que no significa que desapareciera este tipo de fábrica que está bien acreditada en construcciones posteriores.

La información arqueológica sobre estos edificios tardíos es bastante mayor que la disponible para los antiguos, debido a que sus cimentaciones de tapial de argamasa tenían escaso valor pues no se podían desmontar $y$ trasladar para ser reutilizadas ${ }^{60}$, por lo que se han

${ }^{57}$ Giralt, 1998, p. 146.

${ }^{58}$ Almagro, 2008, p. 69.

${ }^{59}$ Graciani y Tabales, 2008, p. 137.

${ }^{60}$ Sólo en casos excepcionales se ha documentado la reutilización de bloques de tapial en obras posteriores como rellenos en muros o cimentaciones.

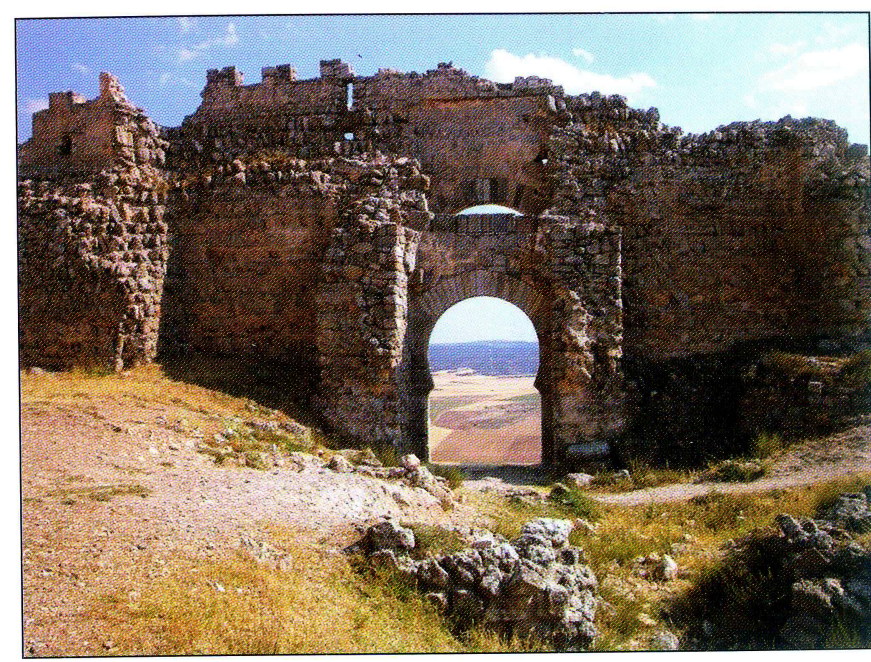

Fig. 13. Cara interna de la muralla del Castillo de Gormaz (Soria). Foto de A. Almagro

conservado mucho mejor que los muros de mampostería ${ }^{61}$. En términos generales, las viviendas tardías son similares a las anteriores en cuanto a su organización espacial, con algunas pequeñas diferencias; básicamente, lo que permite diferenciarlas son los materiales y técnicas constructivas utilizados, sobre todo en sus cimentaciones.

\subsection{Descripción}

Mientras que en la fase anterior los cimientos y zócalos eran de mampostería, en ésta se emplea el tapial de argamasa construyendo así un basamento que suele tener una sola hilada de cajas que alcanza unos 80 ó $90 \mathrm{~cm}$ de alto y un grosor de aproximadamente $50 \mathrm{~cm}$; dos terceras partes de dicha tapia constituían la cimentación propiamente dicha y el resto sobresalía a modo de zócalo (figs. 14 y 15). Hay obras cuyos cimientos llegan a tener más de dos hiladas de cajas de tapial de argamasa, en unos casos

${ }^{61}$ En la ciudad de Murcia se ha descubierto un número considerable de viviendas de esta fase; ciñéndonos a las publicadas, la relación, seguramente no exhaustiva, sería la siguiente: la casa A de Platería (Jiménez y Navarro, 1997); la de calle Marengo, amortizada por el tramo de muralla colindante y fechada por su excavadora a fines del siglo XI o primera mitad del XII (Pujante, 1999, pp. 450 452); la de calle La Manga en su fase I (Guillermo, 1998, pp. 454-457); la de Raimundo de los Reyes, que se ha fechado a mediados del siglo XII (Bernabé, 1994, pp. 134 y 137); la fase II de la gran vivienda de calle Fuensanta (Bernabé y López, 1993, p. 49); las denominadas 1, 2, 3, 4, 5, 6, 10, 11 y 12 halladas en el gran solar del Garaje Villar (Manzano, 1995); la 2 de calle Cadenas (Jiménez, 1993); la de calle Montijo (Bernal y Jiménez, 1993); las siete de calle Cortés (Muñoz, 1999a); la de San Bartolomé; las cinco de Platería; las seis casas de Yesqueros (Robles y Navarro, 1999); las cuatro de Santa Isabel (Muñoz, 1999b), la casa de Mariano Girada (Ruiz Parra, 1999), las nueve casas de Platería 31, 33 y 35 (Ramírez y Martínez, 1999), trece casas más en dos solares de la calle Andrés Baquero (López y Sánchez, 2004; Ramírez; 2004), cinco en Sagastal Aistor (Muñoz y Jiménez, 2004) y dos viviendas en calle Serrano (Muñoz y Jiménez, 2005). 


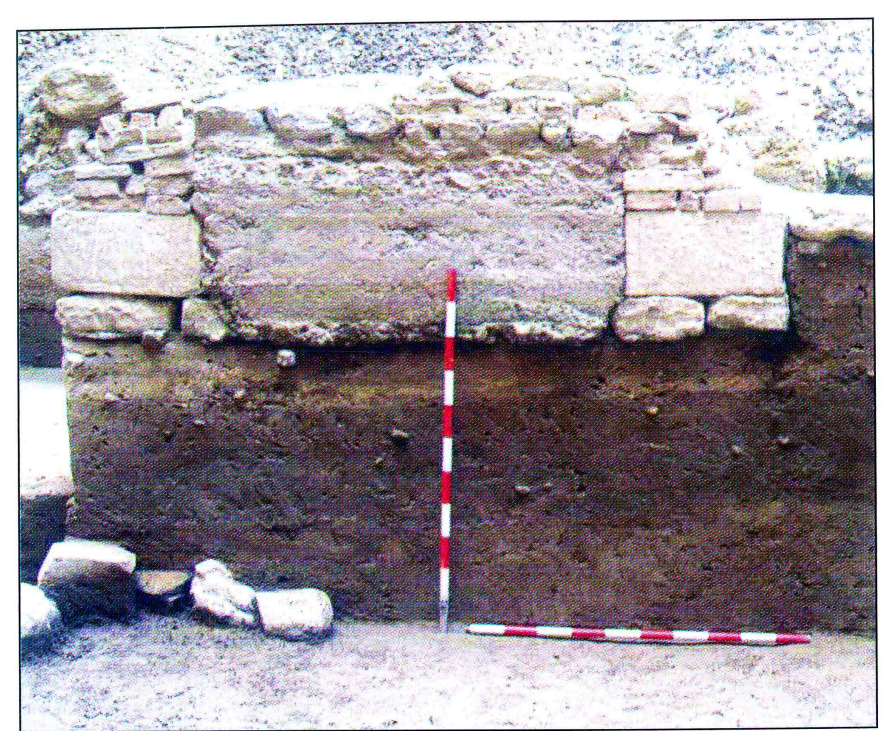

Fig. 14. Casa A de calle Platería de Murcia, nº 14 (s. xII). Muro construido con cimentación de tapial de hormigón y solución mixta en las jambas: cimentación de sillares y alzado de ladrillos

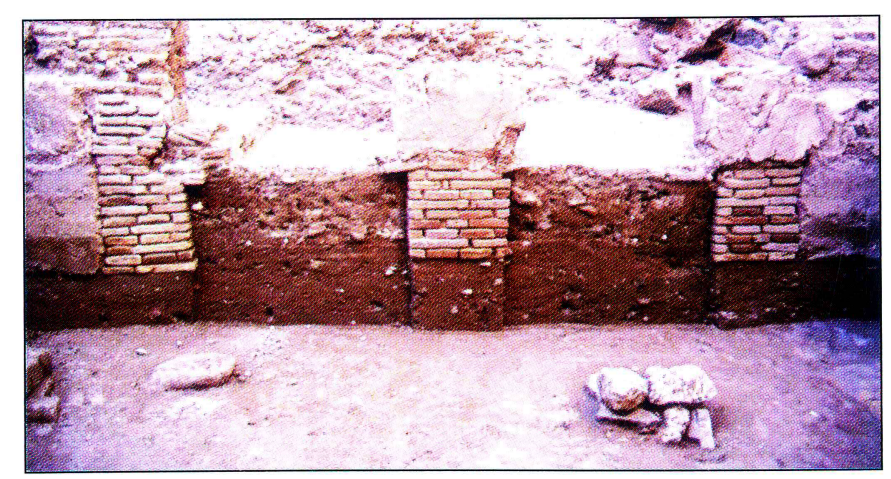

Fig. 15. Casa excavada en el casón de Puxmarina de Murcia (s. XII). Muros construidos con cimentación de tapial de hormigón y jambas y pilar central de un vano geminado fabricados con ladrillo

debido a la necesidad de salvar desniveles mediante muros de contención (fig. 43) y, en otros, con el fin de resolver problemas de estabilidad generados por conducciones de agua profundas, este es el caso documentado en los edificios de Puxmarina (fig. 16) y Belluga ${ }^{62}$. Así se hacían todos los muros de carga pero no necesariamente los de partición, entre los que encontramos citaras y tabiques de panderete fabricados con ladrillos o adobes; también hemos documentado en escaleras la presencia de bóvedas tabicadas construidas con ladrillos ${ }^{63}$.

Los vanos de los muros de carga suelen aparecer ya definidos en sus cimentaciones (figs. 14 y 15), aunque cono-

${ }^{62}$ Jiménez y Navarro, 2002a, fig. 50.

${ }^{63}$ Almagro, 2001, p. 157, fig. 8.

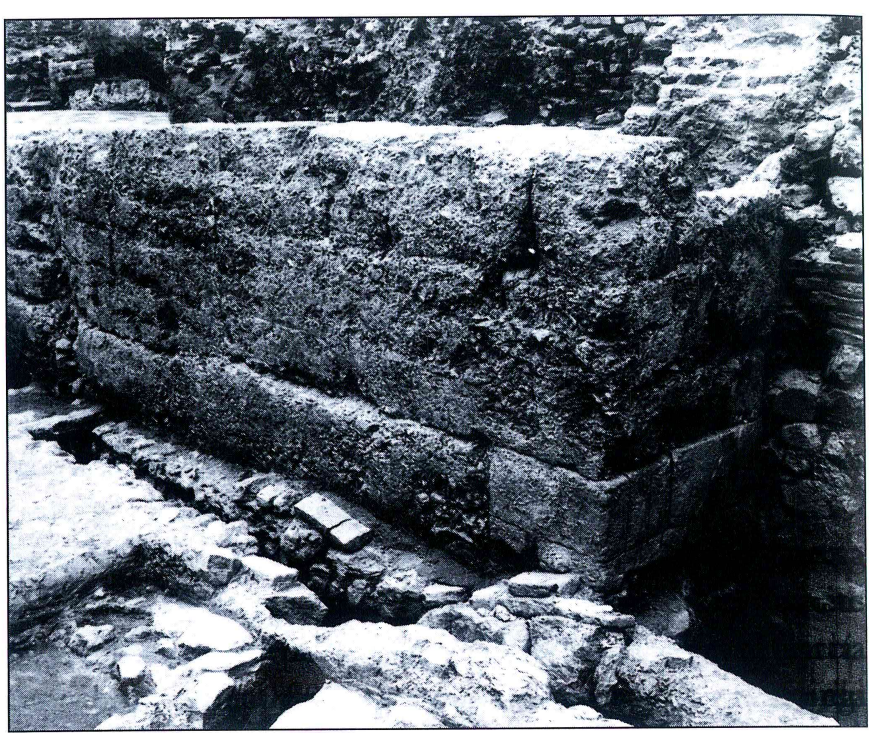

Fig. 16. Casa excavada en el solar del casón de Puxmarina de Murcia (ss. XII-XIII). Véase en el muro de tapial de hormigón cómo ha sido reforzada su esquina con sillares de calcarenita

cemos algunos casos en los que estas infraestructuras son muros corridos en los que no se reflejan los vanos ${ }^{64}$. Las jambas presentan ahora soluciones de refuerzo mediante machones que varían según la cronología: sillares de calcarenita dispuestos a soga y tizón, al igual que en las construcciones de la fase antigua; obra de ladrillo en su totalidad (fig. 15) y una solución mixta de ladrillo con basamento de piedra (fig. 14). Menos frecuentes son los casos en los que las jambas no están diferenciadas constructivamente y, por lo tanto, forman parte de la obra de tapial del muro inmediato, llegando en algunos casos hasta encofrar las propias mochetas; esta solución la hemos visto en la sala norte y crujía oriental de la vivienda A de Platería (fig. 17) y en la casa sur de Organistas ${ }^{65}$. Estos vanos cuyas jambas no fueron reforzadas con una obra diferenciada de ladrillos o piedra, debieron de adoptar en altura la solución conocida como tapial con brencas, consistente en reforzar con un material más resistente la parte de la caja inmediata a la jamba, mientras que en el resto de la tapia se utilizaba el material empleado habitualmente en el resto del muro (figs. 41 y 42 ).

Los pavimentos de los espacios cubiertos, incluidos salones, cocinas y letrinas, solían hacerse con argamasa de cal (fig. 18). Las paredes de las dependencias estaban enlucidas con yeso y algunas de ellas se decoraban con

${ }^{64}$ Véanse, por ejemplo, la casa A de Puxmarina (Jiménez, Navarro y Thiriot, 2005, p. 424) o el edificio comercial de calle Conde Valle de San Juan (Ruiz Parra, 1996).

${ }^{65}$ Navarro y Jiménez, en prensa. 


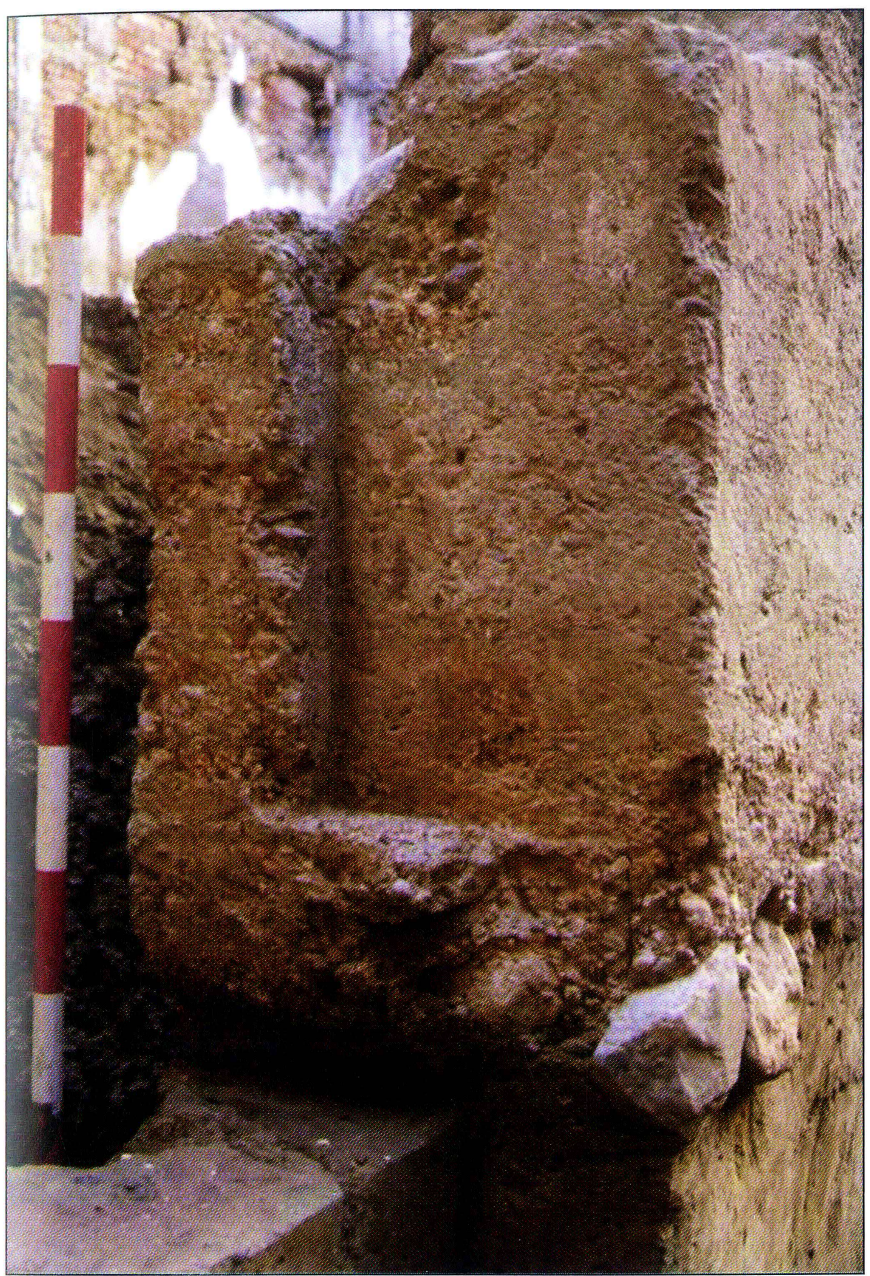

Fig. 17. Casa A de calle Platería de Murcia, no 14 (s. XII). Detalle de la jamba con la mocheta encofrada en la obra de hormigón

motivos en reserva sobre fondo rojo. Las reparaciones de los muros de las viviendas tardías seguían el mismo proceso que explicamos cuando tratamos las de época más antigua.

Como antes decíamos, en ciertas casas de Murcia como la A de Platería y la de calle Sémola así como en el palacio de San Andrés, que se podrían fechar en la primera mitad del siglo XII, los sillares de arenisca se utilizaron con profusión pues, además de encontrarlos en los cimientos de las jambas (fig. 14), aparecen en los umbrales de los vanos, en las solerías de los andenes y, dispuestos a soga y tizón, en el pilar central de la puerta geminada que daba acceso a los salones principales (fig. 19). La antigüedad relativa de esta solución es evidente, pues en aquellos casos en los que se puede rastrear la evolución posterior de la vivienda se observa cómo las jambas se reparan y recrecen con ladrillo, quedando la piedra como testimonio de la fase fundacional. Es posible que estemos ante un simple fenó-

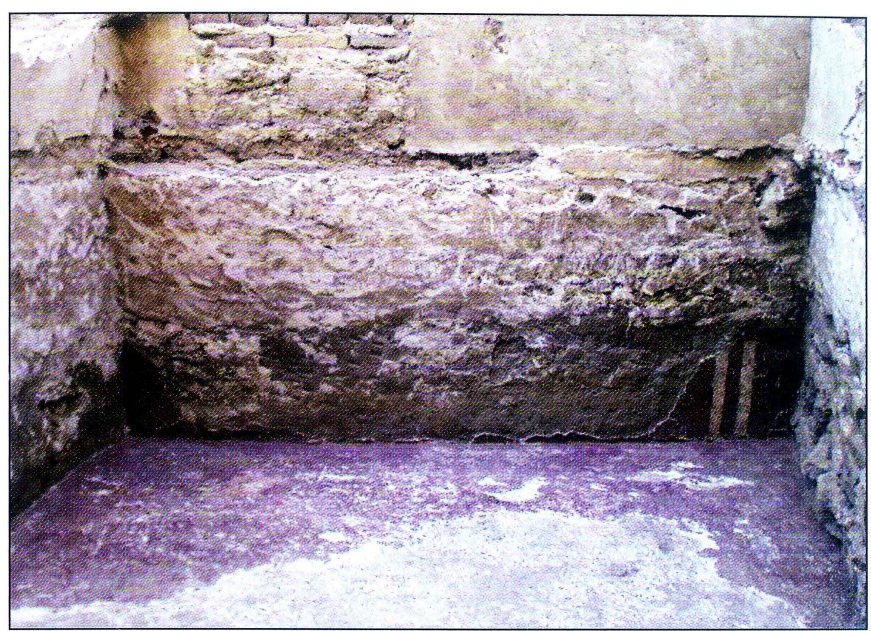

Fig. 18. Casa $n^{\circ} 4$ del solar de plaza de Romea, esquina calle Alfaro de Murcia (ss. XXI). Salón principal norte. Pavimento de argamasa y zócalo, ambos pintados en rojo. En el alzado se conserva un motivo geométrico en reserva compuesto por dos bandas verticales

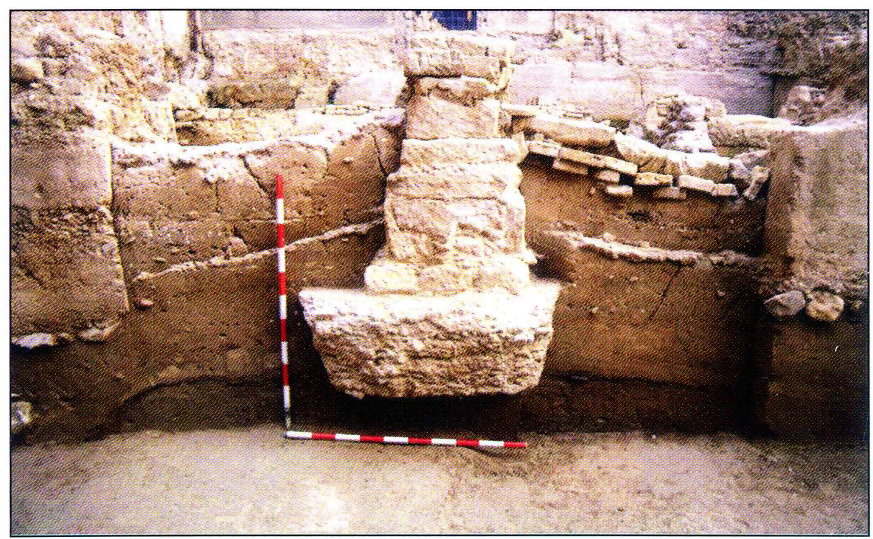

Fig. 19. Casa A de calle Platería de Murcia, no 14 (s. XII). Vano geminado de acceso al salón principal (norte). Las jambas no han sido dotadas de los habituales refuerzos de piedra o/y ladrillo. La cimentación del pilar central está compuesta por una zapata de hormigón sobre la que se asienta la obra de sillares de arenisca. A ambos lados del pilar central se puede ver en el perfil un suelo de trabajo, muy próximo a la base de los muros

meno de reutilización de materiales ${ }^{66}$, procedentes de edificios arruinados o en proceso de demolición, aunque no descartamos que se trate también de una pervivencia de la tradición constructiva de la fase anterior.

A partir de mediados del siglo XII, en la ciudad de Murcia la piedra se empleó aún menos pues prácticamente desaparecen los pavimentos de este material, aunque segui-

${ }^{66}$ Un caso en el que se ve claro que los sillares están reutilizados es el muro de cierre del cementerio de San Nicolás de Murcia (fig. 24), en el que se puede apreciar cómo la obra de tapial de hormigón aparece reforzada por machones de piedra (Jiménez y Navarro, 2001, p. 141). Esta solución también la encontramos en la muralla de la alcazaba Qadima de Granada, fechada tradicionalmente en el siglo XI precisamente por la presencia de este tipo de obra de piedra (fig. 46). 


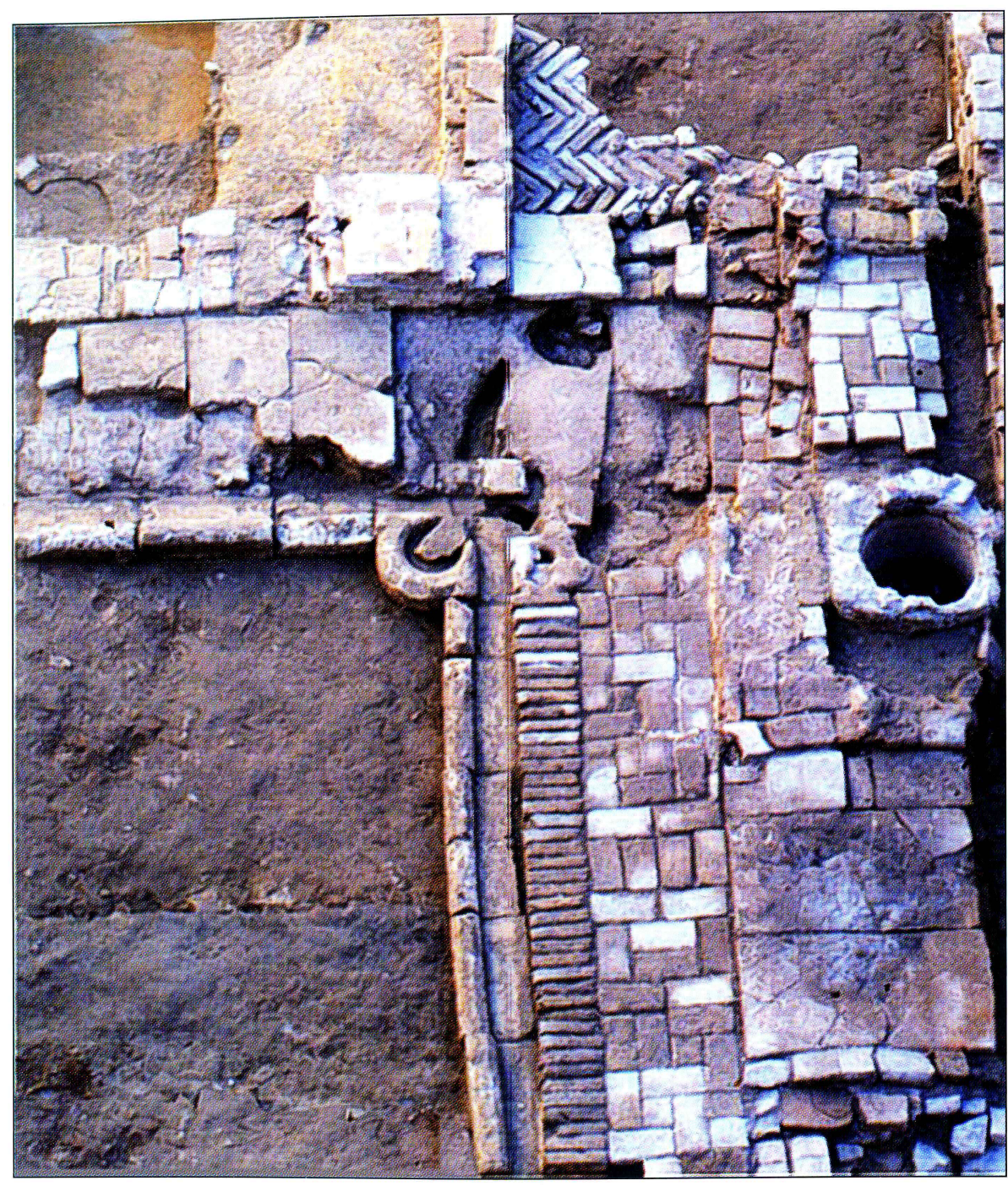

Fig. 20. Casa excavada en un solar de calle Trapería de Murcia (primera mitad del s. XIII). Los umbrales de las puertas que se abrían al patio, el pavimento del tramo de andén que se ve en la parte superior de la foto y el canalillo perimetral del jardín son de piedra, mientras que el tramo del andén de la derecha es una reparación hecha con ladrillos mos hallándola muy bien trabajada en las solerías de los baños (fig. 21). También la encontramos en casas de cierta riqueza constructiva, conformando los canalillos perimetrales que delimitan los jardines en hondo (fig. 20), las fuentes ${ }^{67}$, reforzando esquinas de cimentaciones comprometidas (fig. 16) e incluso aún en solerías, como las de la fase fundacional de la vivienda de Pinares $^{68}$ y las del edificio hallado en calle Montijo ${ }^{69}$, en donde junto con los cimientos de tapial de argamasa hallamos todavía pavimentos con losas de piedra. Fuera de Murcia, en la cercana ciudad de Orihuela (Alicante), exhumamos una de estas solerías en una casa de la calle Hospital (fig. 27).

En relación directa con la decadencia del empleo de la piedra, se encuentra, a partir de mediados del siglo XII, la

${ }^{67}$ Se halló una de estas fuentes en la casa de Pinares (Manzano, López y Fernández, 1993, p. 405); y otra en el Qasr al-Sagîr (Pozo, 1999, pp. 97, 99 y 100).

${ }^{68}$ Manzano, López y Fernández, 1989; id., 1993.

${ }^{69}$ Bernal y Jiménez, 1993, figs. 6 y 18. utilización cada vez mayor del ladrillo en la construcción de jambas, tabiques, pilares y, sobre todo, como solería. Sabemos con seguridad que su empleo generalizado en

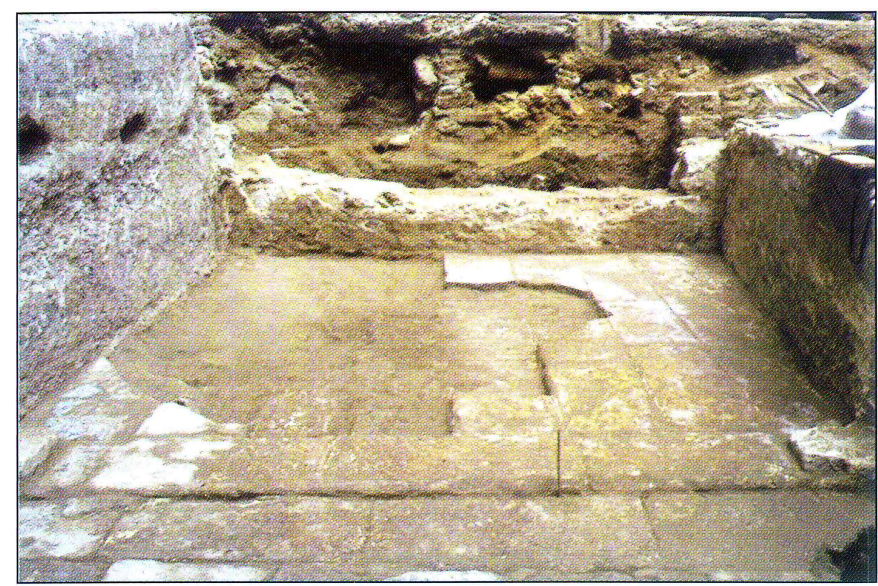

Fig. 21. Baño del Trinquete de Murcia (ss. XII-XIII). Pavimento de losas de piedra de la sala caliente 
Fig. 22. Casa $n^{\circ} 2$ del solar de Plaza Romea esquina calle Alfaro de Murcia (primera mitad del s. XIII). EI salón principal (a la izquierda de la foto) conserva restos de un pavimento de ladrillos a tabla bajo el que se distingue otro anterior de mortero de cal pintado de rojo. El patio está solado con ladrillos a sardinel
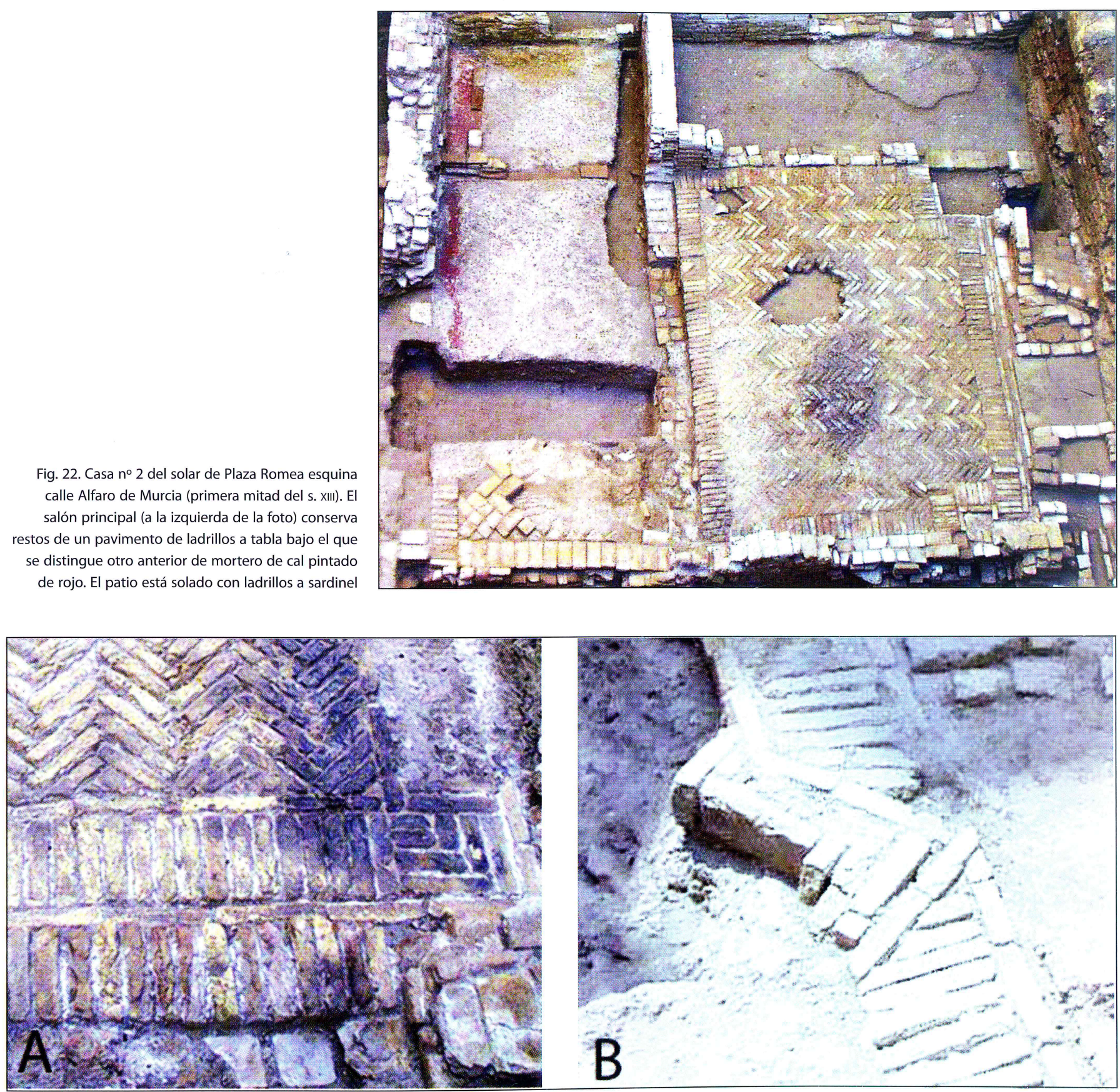

Fig. 23. Casa de calle Victorio de Murcia. Pavimentos de ladrillos a sardinel en espiga del patio (primera mitad del s. XIII). Obsérvese la banda perimetral y el motivo cuadrado con que se resuelve uno de los ángulos (A) y el de planta romboidal que interrumpe el desarrollo normal de la banda perimetral (B)

pavimentos de habitaciones y patios en la Murcia andalusí debió de producirse en una fecha imprecisa entre el último cuarto del siglo XII y el primero del XIII; prueba de ello son las solerías de ladrillo del edificio que hay bajo el palacio que mandara construir el sultán murciano Ibn Hûd alMutawakkil entre los años $1228-1238^{70}$. En los patios de

${ }^{70}$ A estas construcciones sobre las que se construyó el palacio hudí se le ha dado una fecha «avanzada de época almohade difícil de datar con anterioridad al último decenio del siglo XII» (Pozo, 1999, p. 87). las casas murcianas se empleaba el ladrillo en los pavimentos disponiéndolo a tabla o a sardinel en espiga (figs. 22$25)^{71}$. En interiores aparece muy frecuentemente solando los pórticos y los habituales salones con alhanías, aunque en estos casos suelen estar dispuestos a tabla y no a sardinel, casi siempre en espiga y a veces en composición

71 Noticias sobre el empleo del ladrillo como solería de patio también las proporciona el Rawd al-Qirtas, cuando se describe la repavimentación del patio de la mezquita al-Qarawiyin de Fez en el año 1132 (Ibn Abî Zar', 1964, p. 123). 


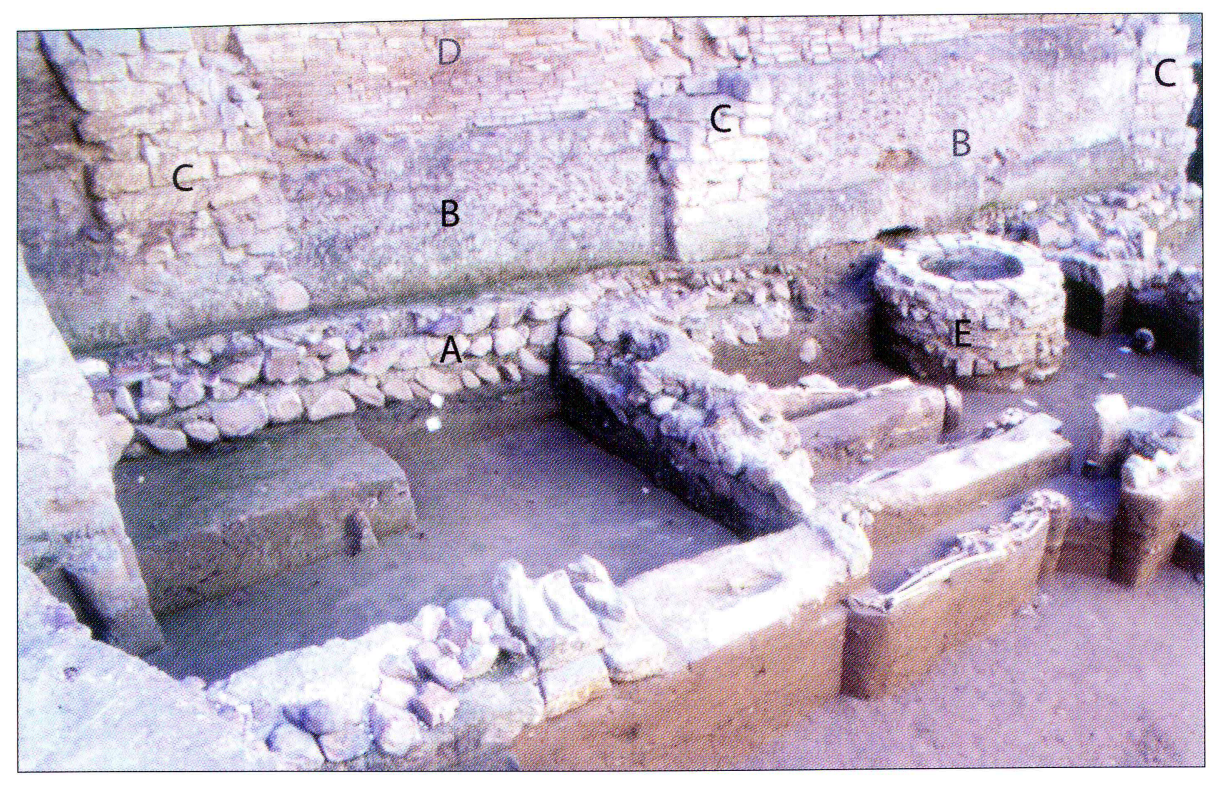

Fig. 24. Casa y cementerio de San Nicolás de Murcia. Los muros de mampostería pertenecen a una vivienda (A) que posteriormente fue convertida en cementerio. La obra de tapial de hormigón (B) y los refuerzos de sillares reutilizados (C) pertenecen a la fase del cementerio. La obra de ladrillo (D) es una reparación del alzado original de tierra que debió tener la cerca del cementerio. El pozo (E) es una infraestructura postmedieval

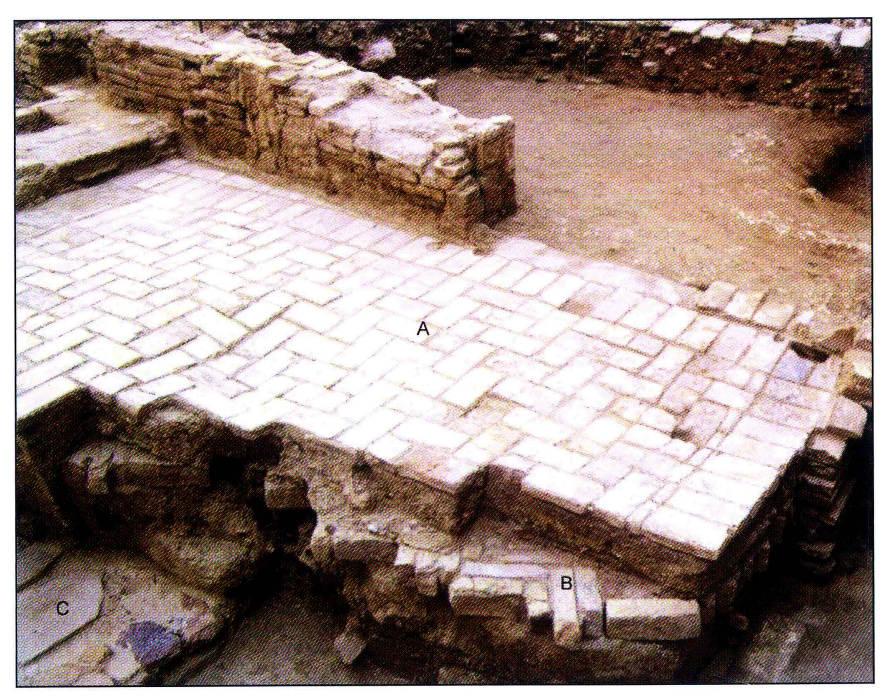

Fig. 25. Casa andalusí de calle Cortés de Murcia. Pavimento del patio. Existen tres solerías: la más reciente está compuesta por ladrillos a tabla en espiga, contorneada por una banda perimetral (A); la intermedia dispone los ladrillos a sardinel en espiga (B); la más antigua son losas de piedra (C)

con olambrillas hechas de ladrillo sin vidriar recortado ${ }^{72}$. Normalmente se intentan diferenciar los espacios arquitectónicos mediante el pavimento y, así, los salones, los pórticos y cualquier otro espacio abierto al patio, reciben un tratamiento diferente respecto a las zonas centrales de los patios. A su vez, también las subdivisiones de dichos espacios se reflejan en el pavimento, de manera que tanto en los suelos de los salones como en los de los pórticos se distinguen habitualmente sus alhanías. Además de los

\footnotetext{
${ }^{72}$ Manzano Martínez, 1995, p. 373.
}

suelos, el ladrillo está presente en donde antes lo estaba la piedra: pilares, jambas, esquinas. También aparece en obras de tapial, intercalado entre las cajas a modo de refuerzo; solución documentada en un tramo de la muralla de calle Verónicas $^{73}$ (fig. 26) y en algunas de las casas halladas en el jardín de San Esteban de Murcia ${ }^{74}$. Esta obra mixta de tapial y ladrillo es denominada por Graciani y Tabales como tapia encadenada, fechándola en el área sevillana a partir de época almohade ${ }^{75}$, cronología que en principio no parece incompatible con los ejemplos hallados en Murcia, si bien ninguno de ellos se encuentra hasta el momento datado con precisión.

La generalización del uso del ladrillo a partir del siglo XII está documentada en buena parte de al-Andalus ${ }^{76}$, aunque conviene, no obstante, matizar esta afirmación debido a la permanente regionalización, o incluso localismo, que impregnó en mayor o menor medida a las producciones artesanales y también a la arquitectura andalusí. En algún caso, la razón fue el aprovechamiento de los recursos que en forma de materiales proporcionara el entorno de los diferentes asentamientos; así por ejemplo, en las viviendas de la Zaragoza islámica abunda el alabastro y se le emplea en los umbrales. En esta última ciudad y en Córdoba también se utiliza el mármol para el mismo fin, fruto del expolio y reutilización de las construcciones romanas. En otros lugares en donde había abundancia de

\footnotetext{
${ }^{73}$ Sánchez González, en prensa.

${ }^{74}$ En la actualidad todavía están inéditas.

${ }^{75}$ Graciani y Tabales, 2008, p. 142.

${ }^{76}$ En ciertos lugares como Mértola, en el Occidente peninsular, convive con la baldosa cerámica, cuadrada o de tendencia rectangular, véase Macías, 1996.
} 
Fig. 26. Muralla de Murcia, tramo de calle Verónicas. Obsérvense las diferentes fases de antemuralla y muralla; en la más reciente de ésta última se aprecia el alzado del lienzo fabricado mediante tapial de hormigón y machones de ladrillo

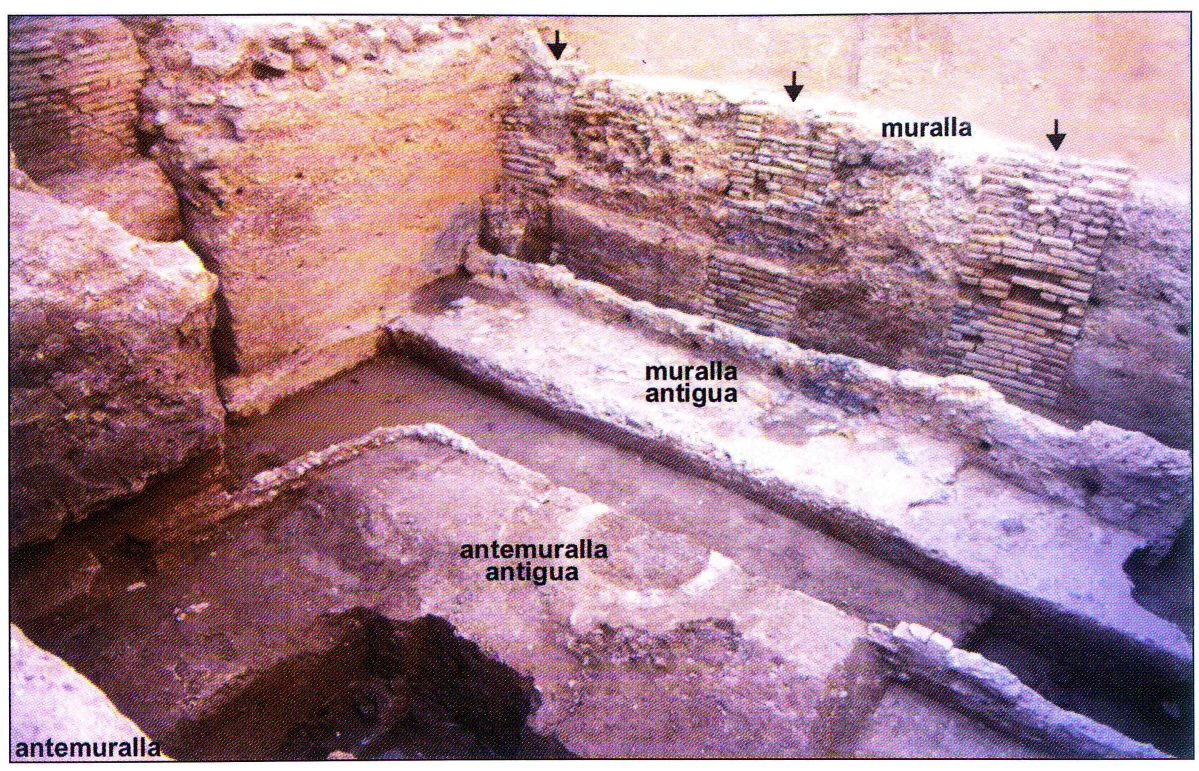

piedra, ésta se siguió utilizando en mayor o menor medida pese a que en general su uso se encontraba en decadencia. Un ejemplo de ello lo encontramos en Orihuela, ciudad que cuenta con excelentes canteras de caliza y calcarenita en sus inmediaciones que, según hemos podido atestiguar, continuó empleándose prolíficamente hasta el momento de la conquista, a mediados del siglo XIII. Buen ejemplo de ello es la casa de calle Hospital, que data del segundo cuarto del s. XIII a juzgar por razones arqueológicas y por elementos arquitectónicos bien fechados como la adopción del vano único como acceso a los salones principales; en ella encontramos estancias pavimentadas con ladrillos y un patio de dimensiones considerables cuyos andenes estaban totalmente solados con piezas de arenisca (fig. 27).

En el mismo sentido, hay datos para afirmar que este cambio no sucedió de manera uniforme en al-Andalus, pues en el área toledana se documenta un aparejo mixto de mampostería y encintados de ladrillo en edificios de los siglos X y XI. Ejemplo de ello son las mezquitas toledanas del Cristo de la Luz (Toledo), fechada por una inscripción en muharram del año trescientos noventa (13 de diciembre de 999/11 de enero de 1000) y la de Tornerías, construida ya en el siglo XI; o los palacios taifas de la Aljafería y Balaguer.

El estudio del módulo del ladrillo no proporciona, con la información de que hoy disponemos, datos relevantes, como se puede comprobar en el cuadro siguiente, en el que hemos incluido sólo ejemplos murcianos que consideramos fechados con garantías y, a modo testimonial, algunos otros ejemplos post-andalusíes. Apenas tenemos ladrillos de la fase más antigua, por lo que sólo

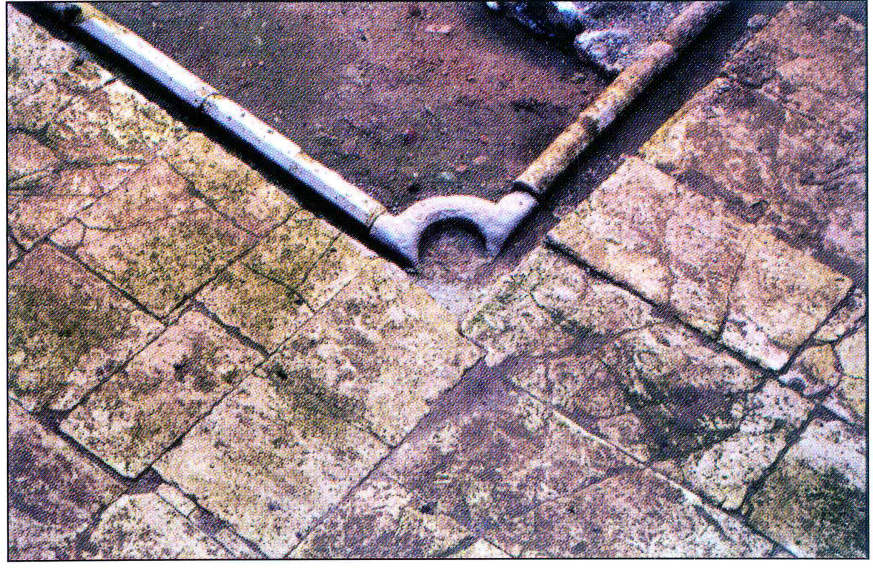

Fig. 27. Casa excavada en calle Hospital de Orihuela (Alicante). Detalle del ángulo del jardín, delimitado por un canalillo perimetral fabricado mediante piezas de piedra labrada, y del andén pavimentado con losas de piedra

con todas las cautelas diremos que son distintos, mayores, que los de la fase reciente. Dentro de ésta, no parece haber diferencias cronológicas pues, como podemos comprobar, los de edificios bien fechados, como los mardanîšíes y los hudíes, separados entre sí casi un siglo, son idénticos. Por lo demás, el análisis de los ladrillos demuestra nuevamente la regionalización a que venimos haciendo referencia pues el módulo general de los ejemplares murcianos de la segunda mitad del siglo XII y primera del XIII $(24 \times 12 \times 4 \mathrm{~cm})$, nada tiene que ver con el ladrillo árabe de un pie $(28 \times 14 \times 4 / 5 \mathrm{~cm})$, característico de la arquitectura almohade sevillana ${ }^{77}$.

${ }^{77}$ Graciani y Tabales, 2008, p. 142. 


\begin{tabular}{|c|c|c|}
\hline Localización & Módulo ladrillos (cm) & Cronología \\
\hline Murcia. Casa 1 de San Pedro & $30^{\prime} 5 \times 16 \times 4^{\prime} 2$ & Siglos $x$ y XI \\
\hline Murcia. Bajo cementerio Sta. Eulalia & $28 \times 14 \times 4$ & Segunda mitad S. XI \\
\hline Recinto inferior del Portazqo & $24 \times 12 \times 4$ & Tercer cuarto de s. XII \\
\hline Recinto superior del Portazgo & $24 \times 12 \times 4$ & Tercer cuarto de S. XII \\
\hline Murcia. Palacio antiguo de Santa Clara & $24 \times 12 \times 4$ & Tercer cuarto de s. XII \\
\hline Murcia. Casa calle La Manqa, fase II & $24 \times 12 \times 4$ & Fines S. XII -inicio del XIII \\
\hline Murcia. Palacio Nuevo de Santa Clara & $24 \times 12 \times 4^{\prime} 5$ & Segundo cuarto del S. XIII \\
\hline Murcia. Casa calle La Manga, fase III & $24 \times 12 \times 4$ & Primera mitad del s. XIII \\
\hline Murcia. Garaje Villar, casa 4, fase II & $24 \times 12 \times 4$ & Primera mitad del s. XIII \\
\hline Murcia. Yesqueros, Nivel III & $24 \times 12 \times 4$ & Primera mitad del s. xIII \\
\hline Murcia. Sta. Eulalia 1-3, casa A, fase 3 & $24 \times 12 \times 4$ & Primera mitad del s. XIII \\
\hline Murcia. Garaje Villar, casa 4, fase II & $30 \times 15 \times 5$ & Primera mitad del s. XIII \\
\hline $\begin{array}{l}\text { Murcia. Reformas palacio Nuevo de } \\
\text { Santa Clara }\end{array}$ & $30 \times 15$ & Último tercio del s. xIII \\
\hline Murcia. Yesqueros, Nivel IV & $30 \times 15 \times 4$ & Segunda mitad del s. XIII \\
\hline Aledo. Torre del Homenaje & $25 \times 15$ & Primera mitad del S. xIV \\
\hline $\begin{array}{l}\text { Murcia. Reparación muralla junto al } \\
\text { Alcázar viejo }\end{array}$ & $28 \times 14 \times 4$ & Siglos XIV ó XV \\
\hline $\begin{array}{l}\text { Murcia. Capilla de S. José (Sta. } \\
\text { Eulalia) }\end{array}$ & $30 \times 15 \times 4$ & Fines del s. XVI \\
\hline $\begin{array}{l}\text { Murcia. Capilla de S. José (Sta. } \\
\text { Eulalia) }\end{array}$ & $30 \times 15 \times 3-4$ & Comienzos S. XVIII \\
\hline
\end{tabular}

Menos fructífero aún se presenta el estudio del módulo del tapial. Ciñéndonos a los casos mejor fechados, observamos que en el edificio mardanîší del Portazgo (tercer cuarto del siglo XII), las tapias miden $80 \mathrm{~cm}$, y en el Castillo de Monteagudo, contemporáneo del anterior, entre 82 y $84 \mathrm{~cm}$. En ciertos muros del Alcázar Mayor, que se levantaron entre fines del siglo XII y principios del XIII, las tapias inferiores miden $1 \mathrm{~m}$ y, en la misma obra, las superiores $80 \mathrm{~cm}$. El Palacio Nuevo de Sta. Clara, fechado con certeza en el segundo cuarto del siglo XIII, presenta tapias que oscilan entre los 85 y los $95 \mathrm{~cm}$; es decir, similares a las de los edificios casi un siglo más antiguos. Pero debemos insistir en el fenómeno observado en el Alcázar, que muestra que en una misma obra las tapias pueden variar en sus dimensiones y no aleatoriamente, sino en función de la altura; esto mismo se aprecia en las murallas del Castillejo de Monteagudo, también mardanîší, cuyas hiladas inferiores están compuestas por tapias de 1 $\mathrm{m}$ de altura, las intermedias miden $80 \mathrm{~cm}$ y la última conservada $70 \mathrm{~cm}$ de altura.

\subsection{La arquitectura mardanîší}

Esta arquitectura es contemporánea de la que los almohades estaban haciendo en la mitad occidental de al-Andalus durante el tercer cuarto del siglo XII. La descomposición del Estado almorávide generó la fragmentación de al-
Andalus en numerosas taifas que resultaron presa fácil para el pujante imperio almohade. Sólo Sharq al-Andalus fue capaz de resistir durante veinticuatro años el avance de los unitarios merced al gobierno de una figura singular: 'Abd Allâh Ibn Sa'd Ibn Mardanîsh (1147-1171), el Rey Lobo. La guerra abierta entre este personaje y los almohades, que culminó en el 1171 con el asedio de Murcia, su capital, impidió por un tiempo la penetración del arte oficial reformado en los territorios de al-Andalus oriental ${ }^{78}$.

Los nueve edificios que se vienen identificando como mardanîš́es tienen funciones diferentes: religiosa (el oratorio del Alcázar Mayor de Murcia) ${ }^{79}$; militar (el castillo de Monteagudo, el de la Asomada y ciertos muros de la alcazaba de Lorca); residencial (el Castillejo ${ }^{80}$, la Dâr as-Sugrà ${ }^{81}$ y Pinohermoso) y tres de naturaleza dudosa, uno de ellos porque hace muchos años que desapareció y sólo se conserva publicada su planta (Los Alcázares), y los otros dos por su estado inacabado (los del Portazgo). Todos ellos están dentro de los actuales límites de la provincia de Murcia, salvo Pinohermoso, que se encuentra en Játiva (Valencia). La única de estas construcciones que sabemos con absoluta certeza que es obra mardanîsí, gracias a las fuentes escritas,

\footnotetext{
${ }^{78}$ Navarro y Jiménez, 1995 b.

79 Sánchez y García, 2007.

${ }^{80}$ Navarro y Jiménez, 1995 b.

${ }^{81}$ Navarro, 1998; Pozo, 1999; Pozo, Robles y Navarro, 2007a.
} 


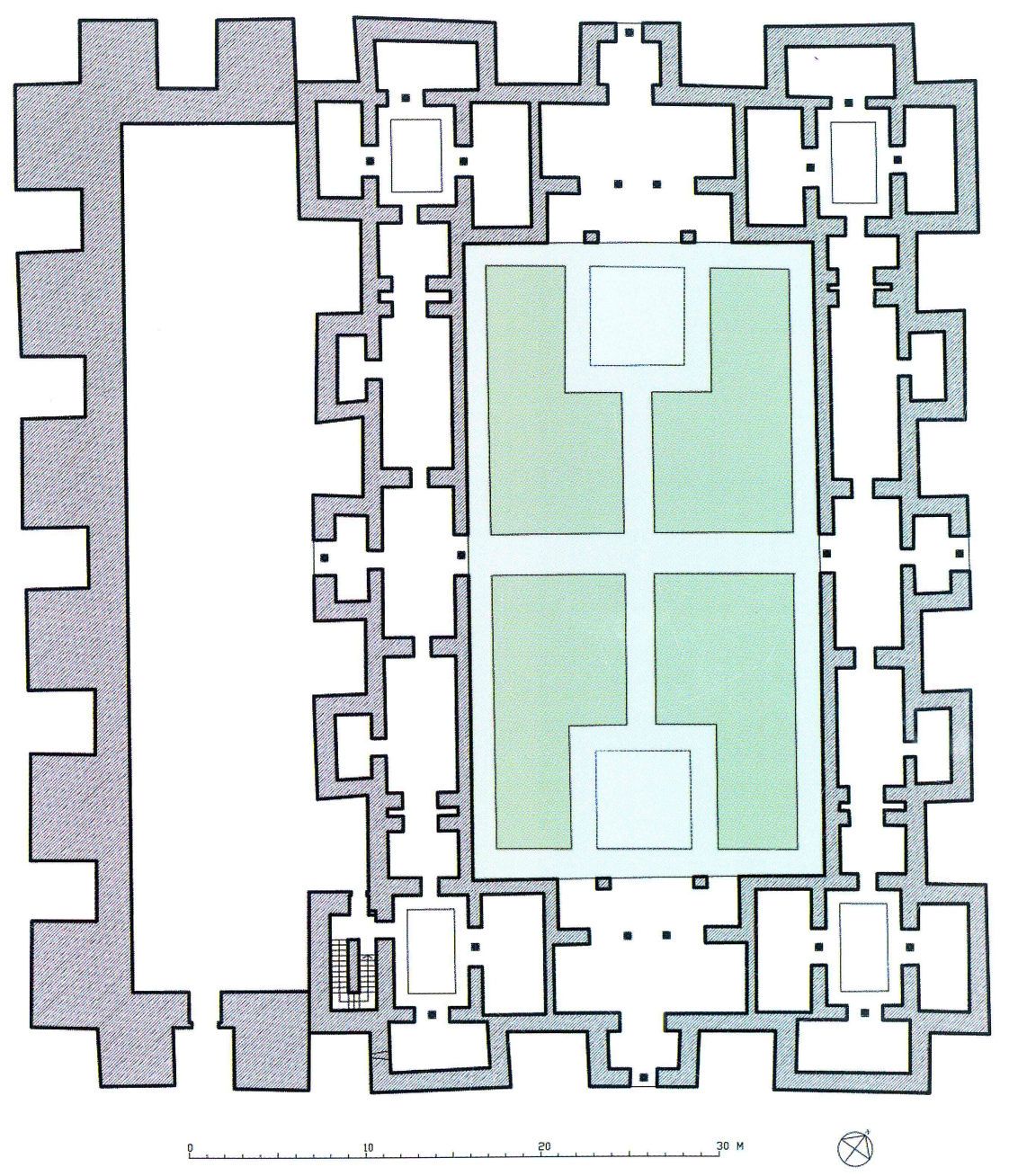

PALACIO DEL CASTILLEJO DE MONTEAGUDO. MURCIA

LABORATORIO DE ARQUEOLOGIA Y ARQUTTECTURA DE LA CIUDAD. ESCUELA DE ESTUDIOS ÁRABES, CSIC

Fig. 28. Planta del Castillejo de Monteagudo (Murcia). Tercer cuarto del s. XII

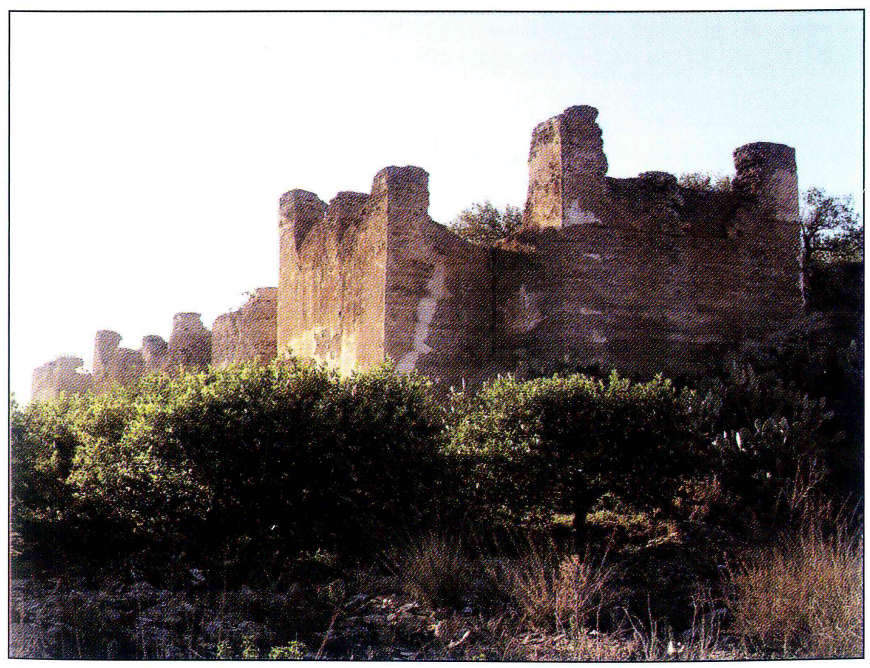

Fig. 29. Castillejo de Monteagudo (Murcia). Vista de la esquina (entrante) noreste del palacio. Tercer cuarto del s. XII es el Castillejo (figs. 28 y 29), y a partir de dicha adscripción hemos identificado los demás por paralelos formales. Una de las peculiaridades de este palacio es la insólita forma de sus esquinas en ángulo entrante, conformadas por la ubicación de sendos torreones en los extremos de cada paño; tal disposición está presente igualmente en el castillo de Monteagudo (figs. 32 y 33), en la fortaleza de la Asomada (fig. 34), en la alcazaba lorquina y en Los Alcázares. El estudio de las yeserías del Castillejo también permitió identificar otra de las características de esta arquitectura, como es el continuismo en los territorios orientales de la taifa de Ibn Mardanîsh de la profusa y exuberante talla del yeso de tradición almorávide en un periodo en el que ya se había impuesto la reforma almohade en el Occidente musulmán. Con el paso del tiempo se pudo comprobar que los yesos que fueron apareciendo en otros monumentos su- 


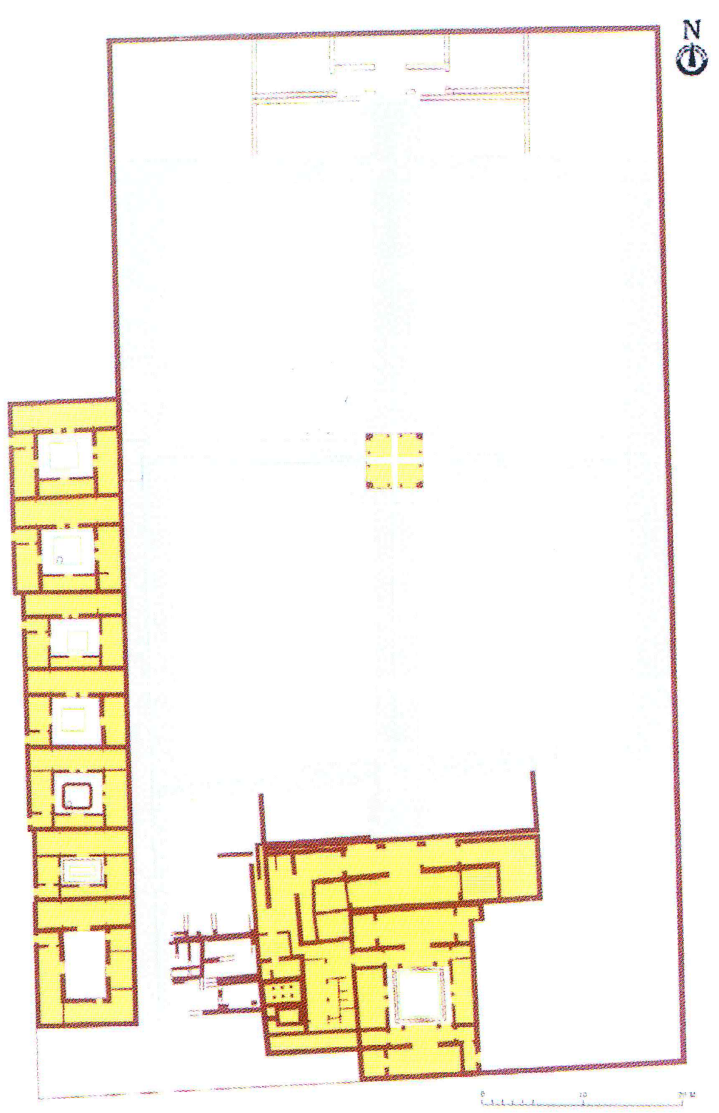

Fig. 30. Dâr as-Sugrà. Jardín de crucero y estructuras del palacio del siglo XII hallados en el subsuelo del convento de Santa Clara la Real de Murcia (Pozo, Robles y Navarro, 2008, fig. 2)

puestamente mardanîšíes eran idénticos a los del primero; así sucedió con los hallados en el castillo de Monteagudo, en el palacio excavado en Santa Clara la Real de Murcia (figs. 30 y 31), conocido en las fuentes árabes como Dâr as-Sugrà y en el mihrab del oratorio del Alcázar Mayor de

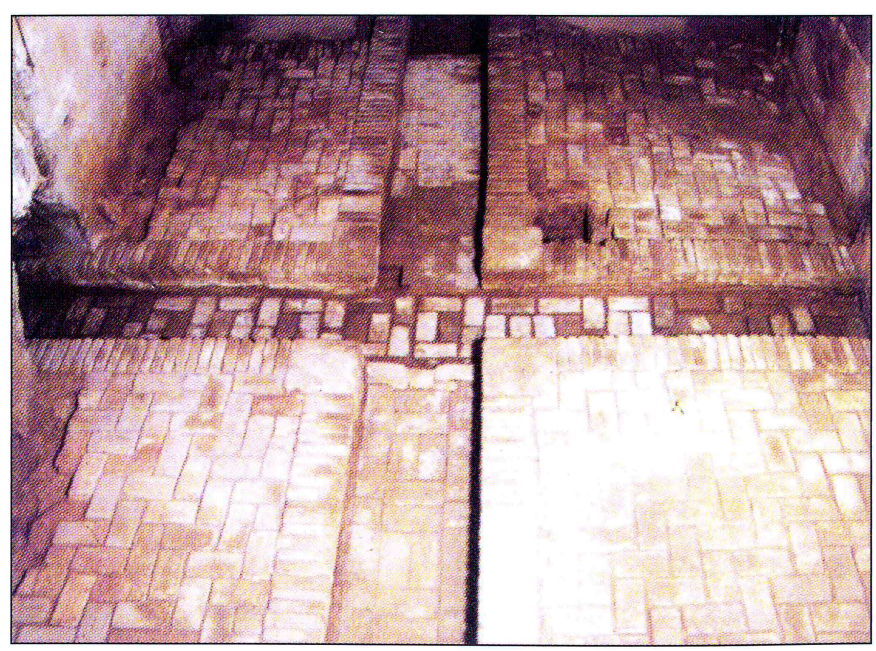

Fig. 31. Dâr al-Sugrà. Palacio mardanisí hallado en el subsuelo del convento de Santa Clara la Real de Murcia. Pavimento del pabellón central del jardín de crucero. Probablemente, la solería de ladrillo es una reforma de época almohade

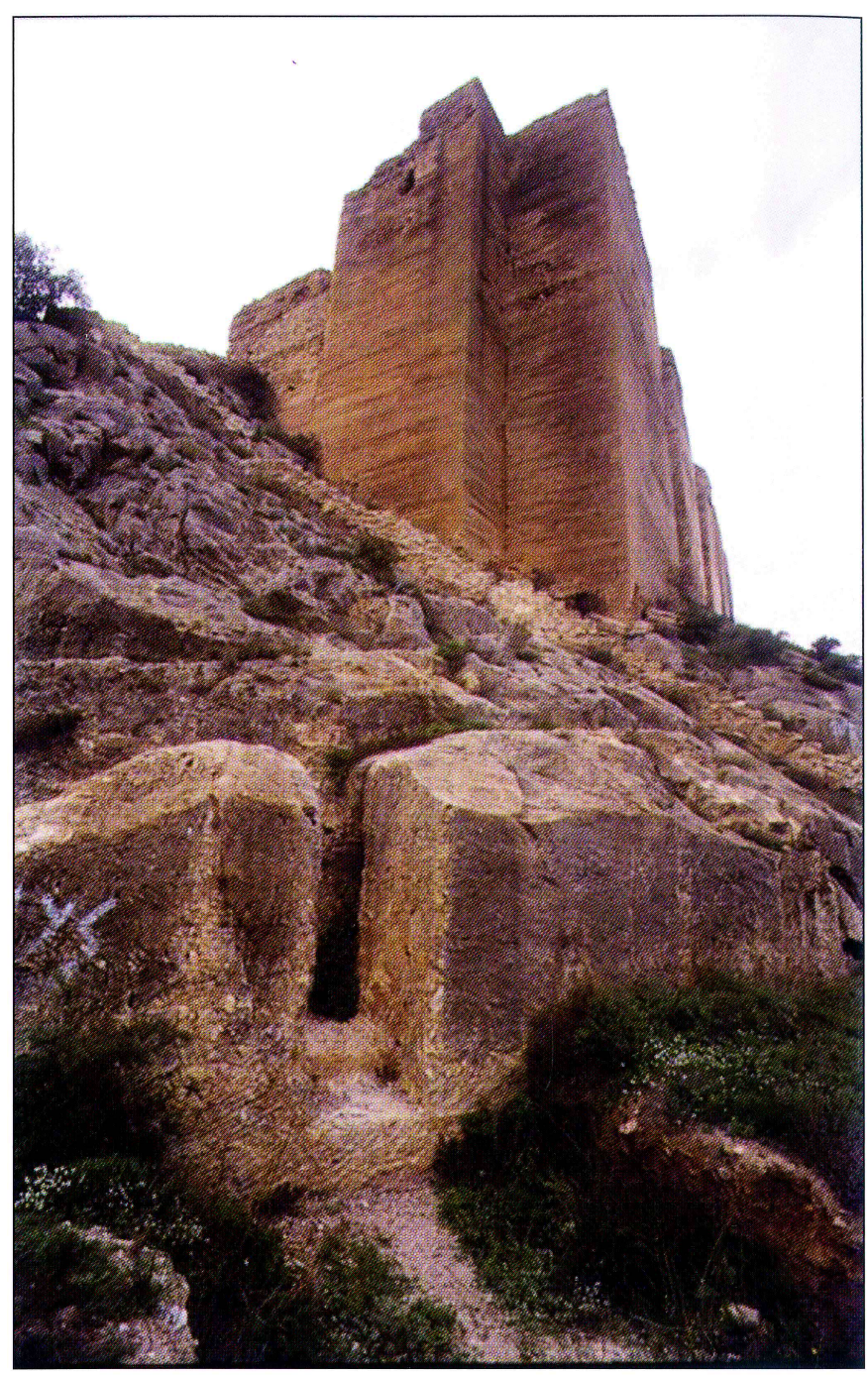

Fig. 32. Castillo de Monteagudo (Murcia). Tercer cuarto del s. XII. Vista de una de las esquinas entrantes del recinto superior

Murcia, lo que parece indicar que se trata de obras de un mismo taller al servicio del programa estatal de Ibn Mardanîsh. Respecto a los yesos de Pinohermoso, no hay duda de que son estilísticamente mardanîšíes, aunque labrados por otros artesanos, quizás porque se trataba de una residencia particular.

La datación de todos estos monumentos en el tercer cuarto del siglo XII es coherente con las características propias de las obras de la fase reciente que acabamos de describir: basamentos de tapial de hormigón reforzados con pilares de ladrillo y bóvedas del mismo material (fig. 33). El ladrillo aparece utilizado selectivamente en las jambas de las puertas ${ }^{82}$.

${ }^{82}$ Un buen ejemplo es el fragmento del arco hallado en las excavaciones del castillo de Monteagudo, en el que se ha conservado tanto la yesería como el pilar de ladrillo al que se adosaba, véase Navarro y Jiménez, 1995b, fig. 6. 
En el oratorio del Alcázar Mayor observamos un predominio de la obra de ladrillo. Según sus excavadores el muro de la qibla "posee una cimentación de mortero de cal, quizá una tapia, y a partir de ésta se superpone un paramento de ladrillo» ${ }^{83}$, con esta descripción es difícil averiguar si el alzado de ladrillo es obra original, o si más bien se trata de una reparación del antiguo muro de tapial. No obstante sabemos con seguridad que al menos el ladrillo del mihrab es original, pues las yeserías mardanîšíes se le superponen; con todas las reservas posibles nos inclinamos por pensar que los muros originales fueron de tapial con machones de ladrillo conformando los vanos, uno de los cuales sería el mihrab, identificando la estructura corrida de ladrillo como una reforma, una vez deteriorado el tapial.

A pesar de la deficiente documentación gráfica con que contamos del momento en el que se excavó el palacio del Castillejo, es posible afirmar, con las fotos antiguas y con los escasos restos que aún existen, que se trata de una obra enteramente construida en tapial reforzado con pilares de ladrillo en las jambas de sus vanos; el módulo de dichos ladrillos es de 22-24 × 11-12 × 4-5 cm.

El ladrillo también fue utilizado para hacer las bóvedas, tal y como se ve en el recinto superior del castillo de Monteagudo (fig. 33), en donde toda una serie de espacios rectangulares, posiblemente almacenes o silos, estaban cubiertos por unas bóvedas de cañón peraltadas fabricadas con ladrillo y trasdosadas por un relleno de argamasa. Las bóvedas arrancan de apoyos entrantes en la fábrica de hormigón, de la misma manera que lo hacen las de la construcción inacabada del Portazgo en donde el material latericio ha desaparecido (fig. 36).

La información arqueológica disponible no permite hablar de un uso generalizado del ladrillo en las solerías de los monumentos mardanîš́ís, como sí sucederá en el primer cuarto del siglo XIII. Prueba de ello es que los pavimentos de las habitaciones del Castillejo, hasta donde revelan las escasas fotografías conservadas de la excavación realizada en los años $20^{84}$, eran obra de mortero de cal. Tampoco en el oratorio del Alcázar Mayor se empleó el ladrillo con este uso, pues allí los arqueólogos documentaron «una delgada capa de yeso» ${ }^{85}$. La solería de ladrillos a tabla delimitada por bandas a sardinel del pabellón central del jardín de crucero de la Dâr as-Sugrà (figs. 30 y 31), es una reforma ${ }^{86}$, posiblemente de época almohade, por lo

\footnotetext{
${ }^{83}$ Sánchez y García, 2007, p. 238.

${ }^{84}$ Algunas fotos de la excavación fueron publicadas en Navarro y Jiménez, 1995 a, figs. 29 y 51

85 Sánchez y García, 2007, p. 241.

${ }^{86}$ Navarro, 1998, p. 108.
}

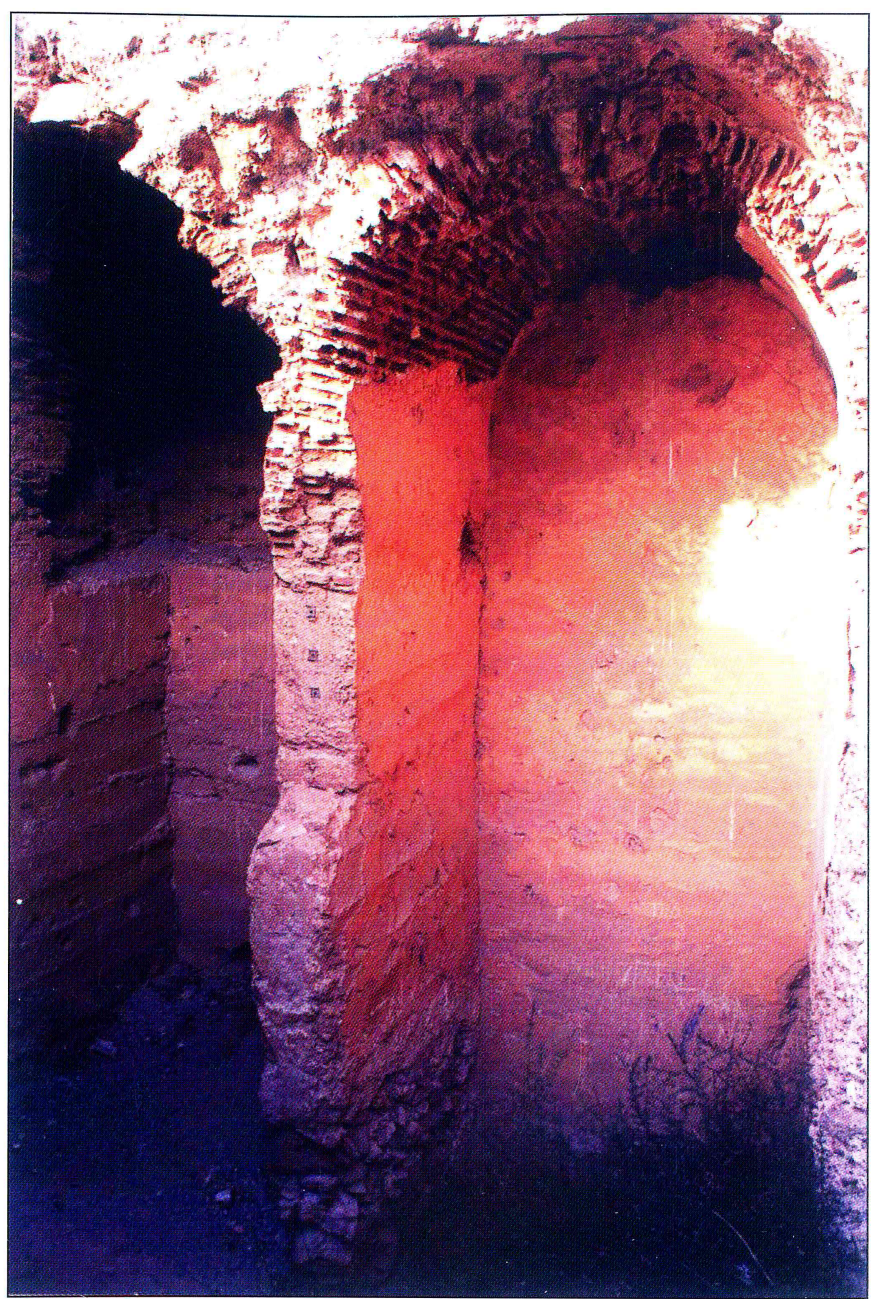

Fig. 33. Castillo de Monteagudo (Murcia). Tercer cuarto del s. XII. Obsérvense los alzados de tapial de hormigón y las bóvedas de ladrillo sobre las que se extiende un relleno de argamasa que permitió crear una superficie aterrazada

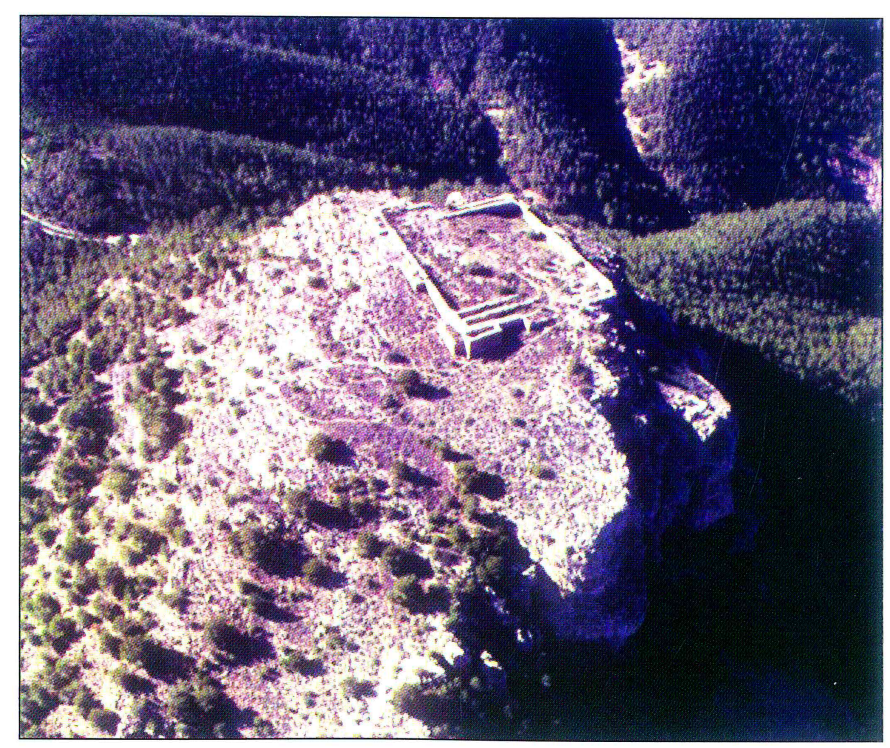

Fig. 34. Fortaleza de la Asomada (Murcia). Tercer cuarto del s. XII 


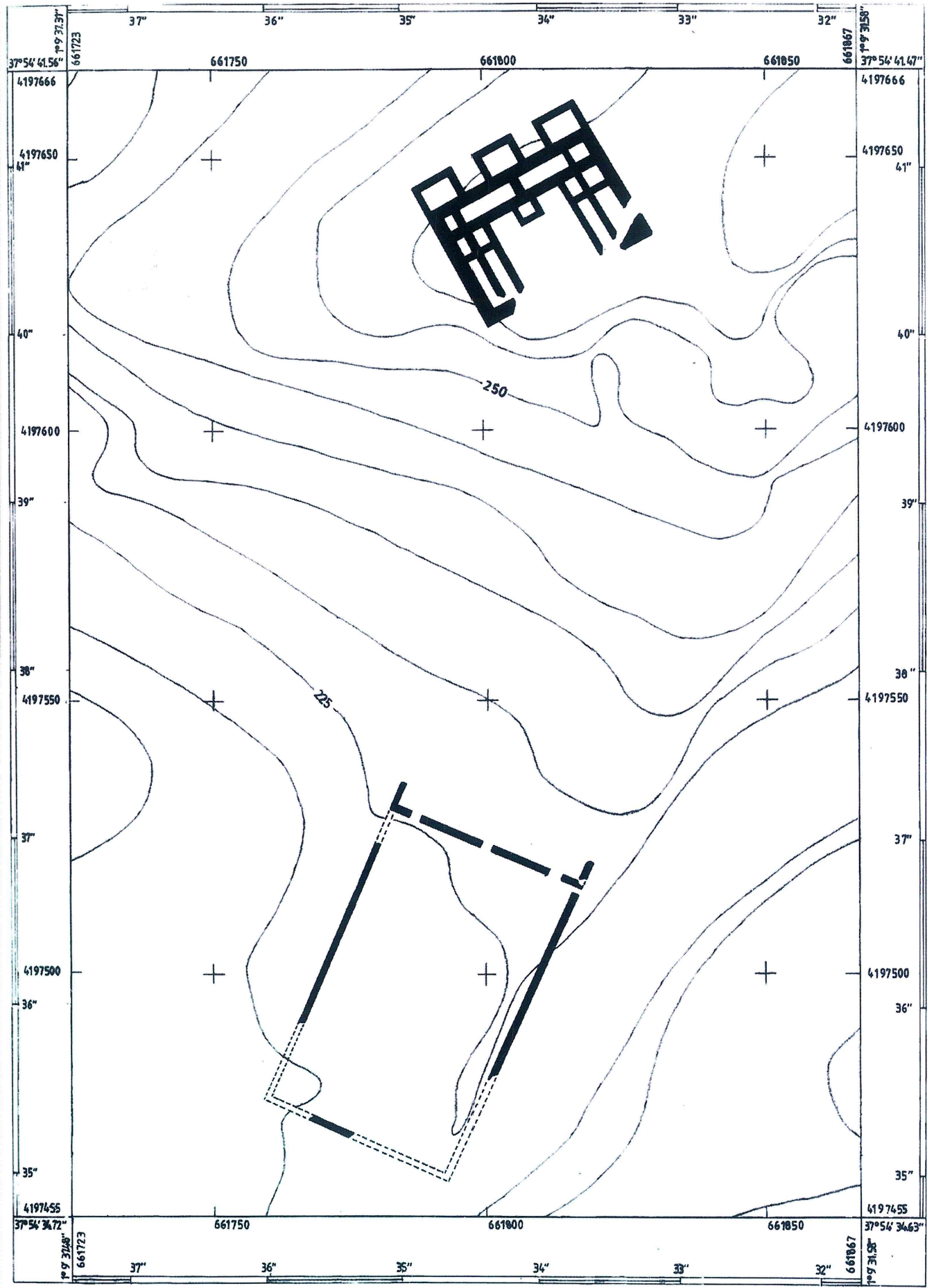

Fig. 35. Planta del conjunto fortificado del Portazgo (Murcia). Tercer cuarto del s. XII

que no puede ser invocada como obra mardanîš́; lo único que es posible asegurar sobre los pavimentos originales de los andenes del crucero es que eran de mortero de cal con losas de piedra arenisca de $32 \times 26 \times 5 \mathrm{~cm}^{87}$.

${ }^{87}$ Pozo, Robles y Navarro, 2007, p. 213.
En la fortaleza de Monteagudo (fig. 32), las tapias de argamasa de cal y piedra presentan una altura de entre 0' 82 y 0 ' $84 \mathrm{~m}$ y la distancia horizontal entre los mechinales oscila entre los 0'50 y 0’60 m. En el Portazgo la altura de las cajas de tapial es de 0 ' $8 \mathrm{~m}$ y su longitud oscila entre 2'22 y 2'46 m. 


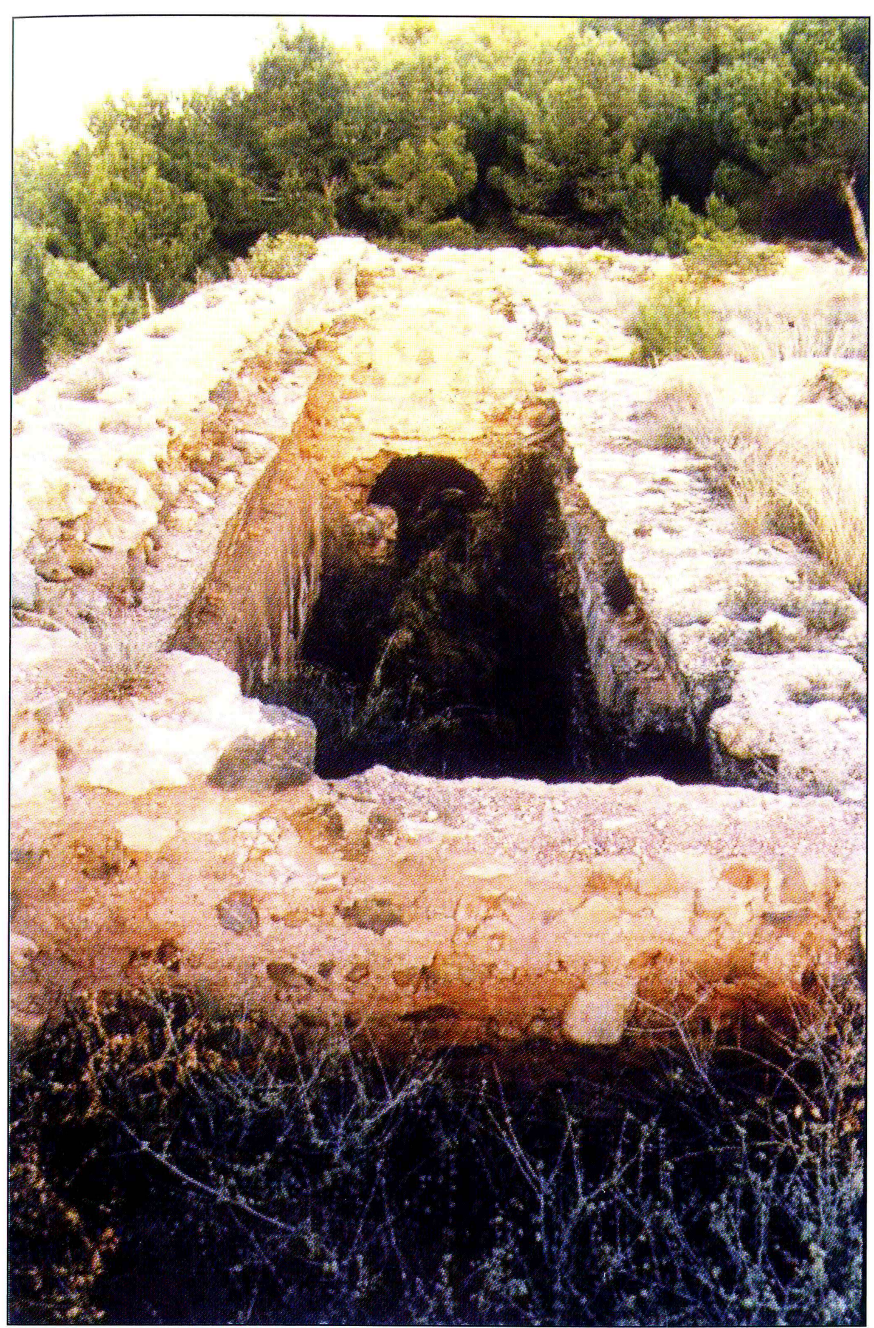

Fig. 36. Recinto superior del Portazgo (Murcia). Tercer cuarto del siglo XII. Obsérvese en la parte superior de la obra de hormigón el retalle para apoyar la bóveda de ladrillo que debía cubrir la crujía

Como ya dijimos, en el palacio del Castillejo las tapias presentan altura decreciente: la primera hilada, que asienta directamente sobre la roca, tiene una altura de $1 \mathrm{~m}$, las superiores $0^{\prime} 80 \mathrm{~m}$ y la última conservada $0^{\prime} 70 \mathrm{~m}$. Los muros perimetrales alcanzan un grosor de 1'50 m y los de las torres, que se adosan a aquéllos, sólo son de $1 \mathrm{~m}$. En el interior del edificio, hoy muy alterado por la presencia de un arbolado de cítricos, los muros no se conservan más allá de $1 \mathrm{~m}$ aproximadamente por encima del nivel del pavimento del sector más elevado (el eje oficial), por lo que ignoramos si el resto del alzado era también de hormigón de cal o de tierra. Al menos la tapia superior de las conservadas no está compuesta exclusivamente de hormigón sino que cuenta con un relleno de tierra en el interior, mientras que la argamasa se acumula en los extremos de la caja conformando rafas o machos que vienen a coincidir con las partes más expuestas de la obra: las esquinas y jambas; a esta técnica se le denomina tapial con brencas ${ }^{88}$. De hecho, en la actualidad han desaparecido los rellenos de tierra y en la silueta del Castillejo se destacan solitarias las esquinas de los torreones (fig. 29). En sus paredes hay restos que indican que estuvieron estucadas y en algunos casos los zócalos se decoraban mediante complejos dibujos geométricos pintados en rojo $^{89}$. También las fachadas exteriores presentaban enlucido de yeso, sobre el que se grabaron dos «sellos de Salomón» como amuletos protectores $^{90}$.

Como es habitual en las construcciones de esta época, la presencia de la piedra es muy escasa, lo que se acentúa aún más en algunos monumentos mardanîšíes debido a su carácter inconcluso. El único edificio que ha proporcionado datos significativos a este respecto es el Castillejo de Monteagudo que fue el palacio de recreo de Ibn Mardanîsh por lo que tiene que ser tenido en cuenta como una obra singular, alejada en algunos aspectos de la arquitectura de su época. Por este motivo debemos ser cautos a la hora de extrapolar a otras construcciones la información que nos ofrece sobre el uso de la piedra. Hecha esta aclaración conviene indicar que el Castillejo fue destruido y expoliado por los almohades, por lo que la piedra hallada allí es una pequeña muestra de lo que tuvo. Durante su excavación en los años 20 del pasado siglo se recuperaron un fragmento de fuste de columna, una basa y dos capiteles todo ello de mármol salvo uno de los capiteles, al parecer de alabastro. Tanto la basa como el fuste se encuentran actualmente extraviados. Gracias a una fotografía sabemos que la basa presentaba, sobre el plinto cuadrangular, una escocia ancha entre sendos toros o baquetones ${ }^{91}$. Los capiteles son de orden compuesto y de su ubicación en el edificio no tenemos dato alguno. Pudieron sostener algunos de los arcos de los pórticos que precedían a las dos salas principales situadas en los lados menores del palacio, o bien servir de parteluz a los vanos de ingreso a dichas salas. Desconocemos si estamos ante piezas reutilizadas o si por el contrario fueron talladas ex profeso para el Castillejo. Lo que sí nos parece claro es que para mediados del siglo XII el capitel de yeso está generalizado y prueba de ello son los numerosos ejemplares de las mezquitas almohades, excepto la de Hassan en Rabat, y el ejemplar de Pinohermoso.

\footnotetext{
${ }^{88}$ Villanueva, 1827 , p. 28 , lám. iv-2.

${ }^{89}$ Navarro y Jiménez, 1995a, figs. 51-53.

${ }^{90}$ Navarro y Jiménez, 1995a, fig. 54; también se pueden ver en las figs. 27 y 36.
}

${ }^{91} \mathrm{La}$ foto antigua se puede ver en Navarro y Jiménez, 1995a, fig. 48. 


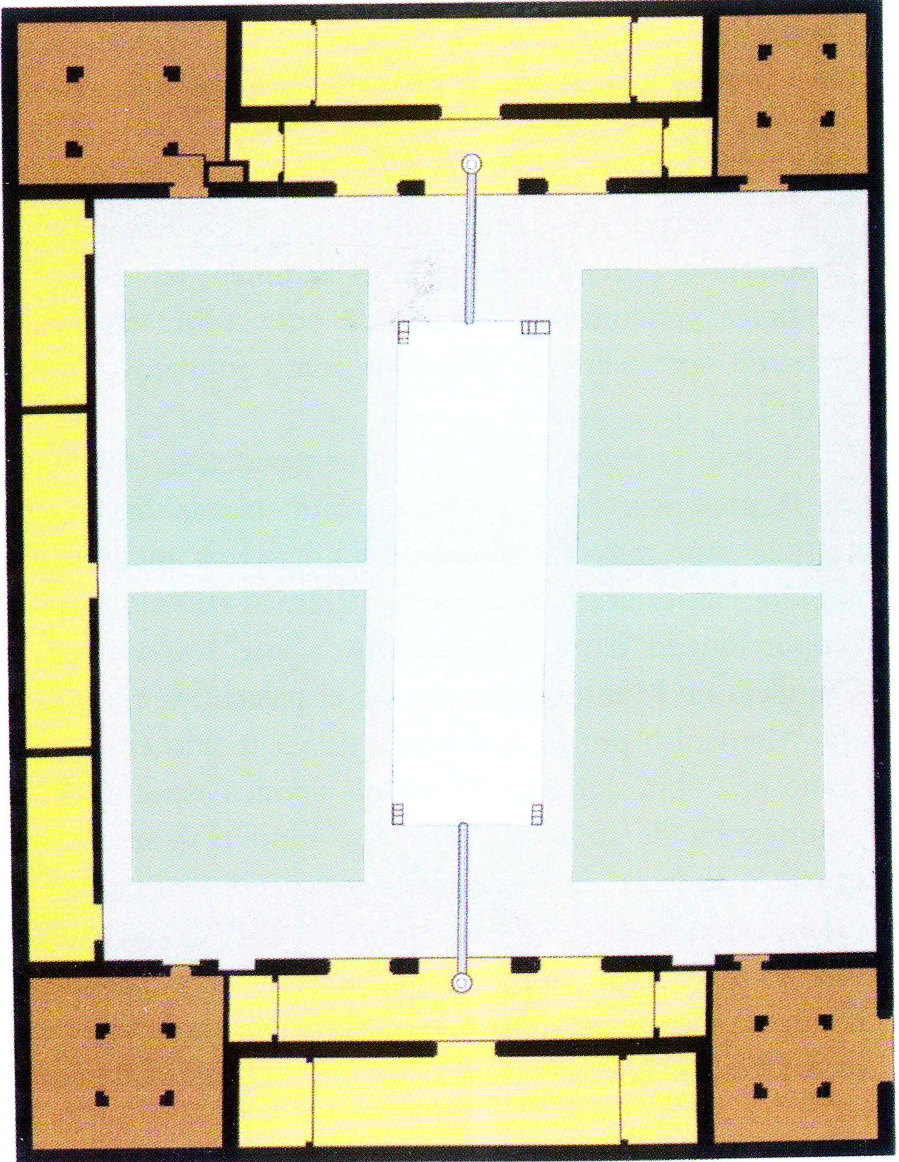

$\stackrel{10}{10} \underbrace{20 \mathrm{M}}$

\subsection{La arquitectura hudí: el Qasr al-Sagîr (circa 1230)}

Hemos identificado el palacio conocido en las fuentes cristianas del siglo XIII como "Alcacer Ceguir» (al-Qasr al-Sagîr), como obra del sultán murciano Ibn Hûd alMutawakkil (1228-1238) $)^{92}$, personaje que encabezó la sublevación que expulsó a los almohades de la Península y que durante diez años controló casi todo al-Andalus hasta su asesinato a manos de un partidario de Ibn alAhmar, el fundador de la dinastía nazarí. Está situado en Murcia, la antigua capital de Ibn Hûd y fue construido

\footnotetext{
92 Tras las primeras excavaciones que uno de nosotros (JNP) dirigió durante los años 80 en el frente septentrional del palacio, este edificio se dató en época de Ibn Hûd al-Mutawakkil (Navarro, 1995, p. 200), posteriormente el arqueólogo que excavó el sector meridional llegó a proponer la posibilidad de que el edificio fuera construido después de 1243, es decir bajo protectorado castellano (Pozo, 1999, p. 77; Pozo, Robles y Navarro, 2007b, pp. 282 y 285). La crítica a esta última propuesta se puede ver en dos trabajos recientemente publicados: Navarro y Jiménez, 2009, pp. 716-718; Navarro y Jiménez, 2011, pp. $177-182$
}

Fig. 37. Qasr al-Sagîr. Segundo cuarto del siglo XIII. Planta de los restos conservados y restitución hipotética (Pozo, Robles y Navarro, 2007)

sobre las ruinas de la Dâr as-Sugrà mardanîsíi y en la actualidad forma parte del convento de Santa Clara la Real.

El edificio principal del palacio era de planta rectangular con un patio central en el que se exhumó una amplia alberca rectangular dispuesta en su eje mayor. En los lados menores del patio vemos la tradicional disposición de salones rectangulares con alhanías laterales precedidos por sendos pórticos. Éstos, al igual que los salones, muestran la habitual organización tripartita al disponer también en los extremos de alhanías atajadas por pilastras de ladrillo (fig. 37).

La cimentación de los muros de carga se hizo tomando como punto de partida el suelo de los edificios del siglo XII (fig. 31) y consiste en una fosa excavada en éste, colmatada de hormigón y piedra, sobre la que se levantó una obra de tapial. Posteriormente estas cimentaciones fueron soterradas aportando escombros procedentes del palacio anterior. Las jambas de los vanos, tanto en cimen- 


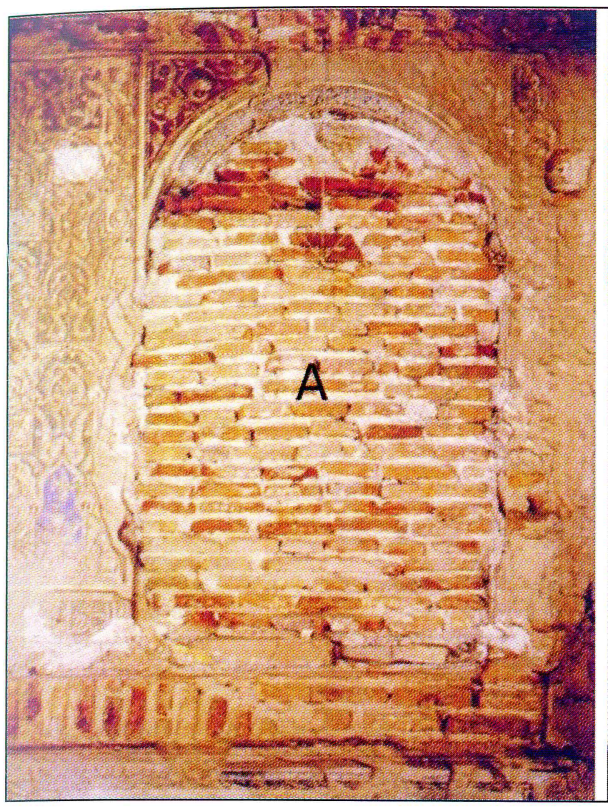

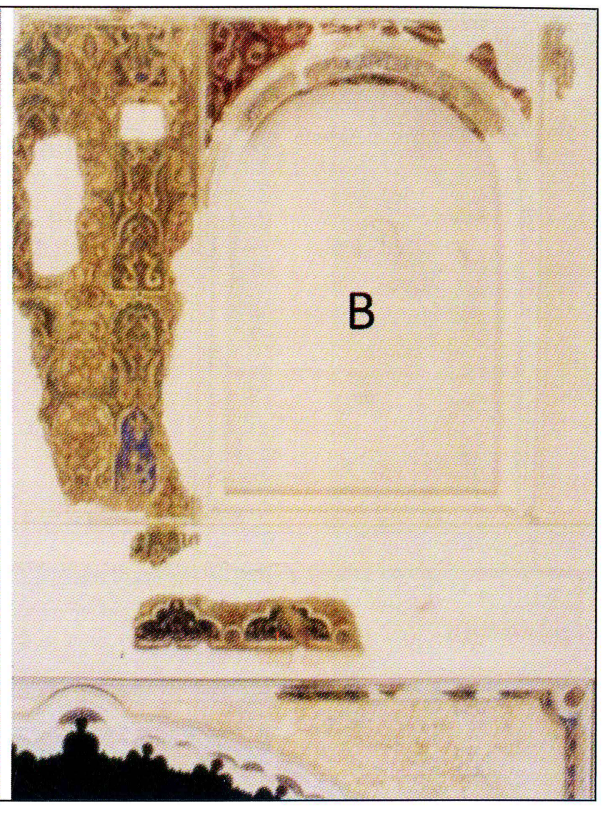

Fig. 38. Qasr al-Sagîr. Segundo cuarto del siglo xIII. Parte superior derecha de la portada de ingreso al salón norte, antes (A) y después (B) de su restauración. Obsérvese cómo bajo el arco ornamental de yeso (angrelado) hay otro de carácter estructural de ladrillo tación como en alzado, son pilares de ladrillos cuyo módulo es de $24 \times 12 \times 4$ '5 cm (fig. 39).

Técnicamente, por tanto, no existe apenas variación con respecto a la arquitectura mardanîsí, aunque hay una

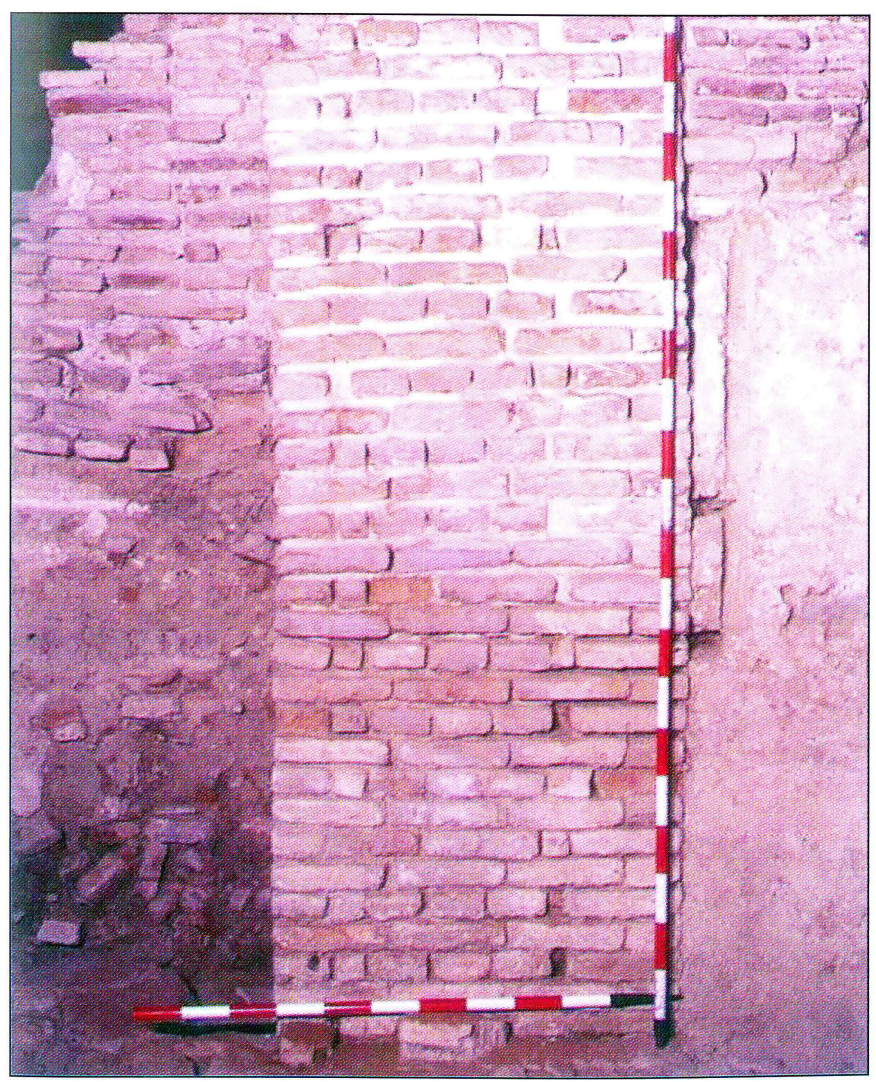

Fig. 39. Qasr al-Sagîr. Segundo cuarto del siglo XIII. Cimentación de ladrillo de la jamba occidental del vano de acceso al salón norte diferencia cuantitativa: en época hudí el empleo del ladrillo, especialmente en las solerías, estaba ya generalizado. En efecto, salones y alcobas del Qasr al-Sagîr estaban pavimentados con ladrillos en espiga a tabla del mismo módulo que los empleados para los machones, mientras que en los umbrales se disponían ladrillos a sardinel. En tres de las cuatro alcobas de los pórticos se han conservado restos de los pavimentos que curiosamente no son iguales: dos de ellas presentan ladrillo en espiga a sardinel, mientras que la tercera está solada con una espiga de ladrillos a tabla ${ }^{93}$.

Como herencia de la arquitectura del siglo XII, también se utilizó el ladrillo en todos los pilares y arcos estructurales; a estos últimos se les adosaban los arcos ornamentales angrelados tallados en yeso (fig. 38), tal y como se puede también observar en las arquerías arruinadas de la mezquita almohade de Tinmal ${ }^{94}$. Los arcos angrelados de las alhanías, con un intradós mucho más estrecho debido a que no son estructurales, no tienen en su interior arcos sustentantes de ladrillo, pues son de carácter exclusivamente ornamental, armados mediante estructuras de madera recubiertas por la obra de yeso, tal y como se puede ver en numerosos ejemplos hallados en Siyâsa ${ }^{95}$.

De la cubierta del espacio central del salón norte, que es el único que nos ha llegado en alzado, sólo pudimos estudiar los restos del estribo de madera en el muro septentrional, dato que nos permite suponer la presencia de la habitual armadura. En las alhanías debieron de existir

${ }^{93}$ Pozo, 1999, pp. 56 y 57, fig. 1.

${ }^{94}$ Ewert y Wisshak, 1984, pp. 31-48.

${ }^{95}$ Navarro y Jiménez, 2007a, pp. 279 y 280. 
alfarjes, tal y como se ve en la techumbre del Palacio de Pinohermoso ${ }^{96}$.

A diferencia de lo visto en el Castillejo de Monteagudo en donde los capiteles son de piedra, los seis ejemplares documentados en este palacio hudí son de yeso y pertenecen a las semicolumnas adosadas que sostienen los arcos de las alhanías de los salones ${ }^{97}$.

\subsection{Siyâsa y el contexto rural}

Dentro de este segundo grupo que genéricamente hemos denominado «arquitectura tardía», vamos a tratar también los materiales y técnicas constructivas que se utilizaron en poblaciones más pequeñas de la Murcia andalusí durante los siglos XII y XIII. Aunque son varios los yacimientos con estas características que podríamos estudiar ahora, el más importante es sin duda Siyâsa, por lo que nos centraremos en él con más detalle y luego trataremos los otros con más brevedad. A simple vista, estos yacimientos presentan un panorama muy diferente de lo documentado en la ciudad de Murcia a causa, en nuestra opinión, de su carácter rural. Es evidente que no contaron con un artesanado desarrollado ni con la riqueza de materiales manufacturados propios de los centros urbanos, por lo que estuvieron muy condicionados por los materiales existentes en su entorno más inmediato $^{98}$.

El despoblado de Siyâsa es un típico asentamiento andalusí en altura, próximo a la actual población de Cieza (Murcia), al que al-Idrîsî (del siglo XII) califica como hisn, término que se aplicaba a los asentamientos que, por su tamaño y condición administrativa, se situaban en una categoría intermedia entre las medinas y las alquerías ${ }^{99}$. Estamos ante una población secundaria en la que no residió la élite política o económica propia de las ciudades. Por esta razón no se han localizado viviendas de la entidad de algunas de las excavadas en asentamientos plenamente urbanos como Murcia, Orihuela o Lorca, caracterizadas por su gran extensión y por no estar condicionadas por el empleo de los pobres materiales locales. Las excavaciones que llevamos a cabo en este despoblado, abandonado en la segunda mitad del siglo XIII, poco después de la conquista cristiana, pusieron al descubierto un conjunto de 19 casas, fechables mayoritariamente entre mediados del s. XII y

${ }^{96}$ Torres Balbás, 1963.

${ }^{97}$ Navarro, 1995, p. 198, fig. 132 y 133; Navarro y Jiménez, 2011, fig. 5; Pozo, Robles y Navarro, 2007b, p. 293.

${ }^{98}$ Para un periodo más antiguo Azuar hace algunos comentarios de interés sobre el continuismo de las técnicas constructivas en el medio rural (2009, p. 28).

${ }^{9}$ Acerca de este yacimiento véase Navarro, 1990a; id., 1991a; Navarro y Jiménez, 1995c; id., 1996. El estudio más completo se puede encontrar en la monografía que publicamos en 2007 (Navarro y Jiménez, 2007a).

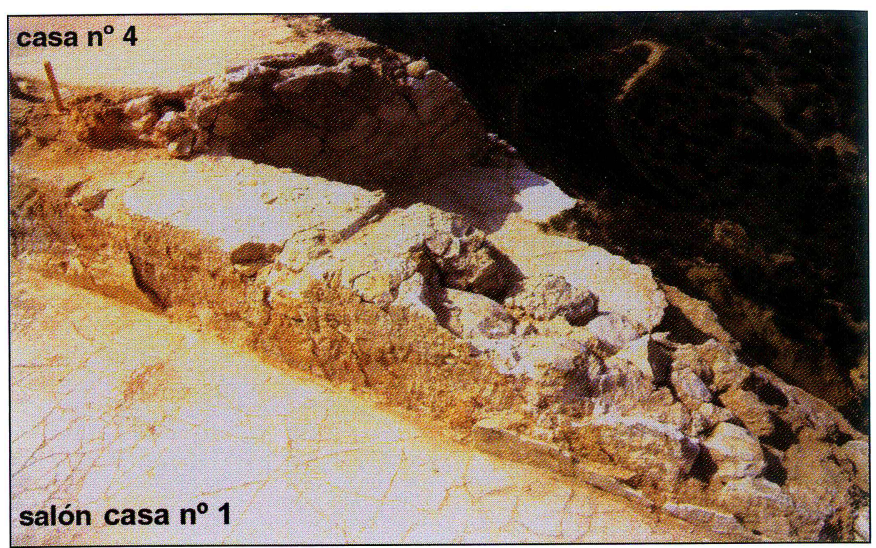

Fig. 40. Siyâsa (Cieza), casa 1. Zócalo de tapial de mampostería con yeso sobre el que se disponía el alzado de tierra. Apréciese la huella de un mechinal del encofrado de la caja superior desaparecida

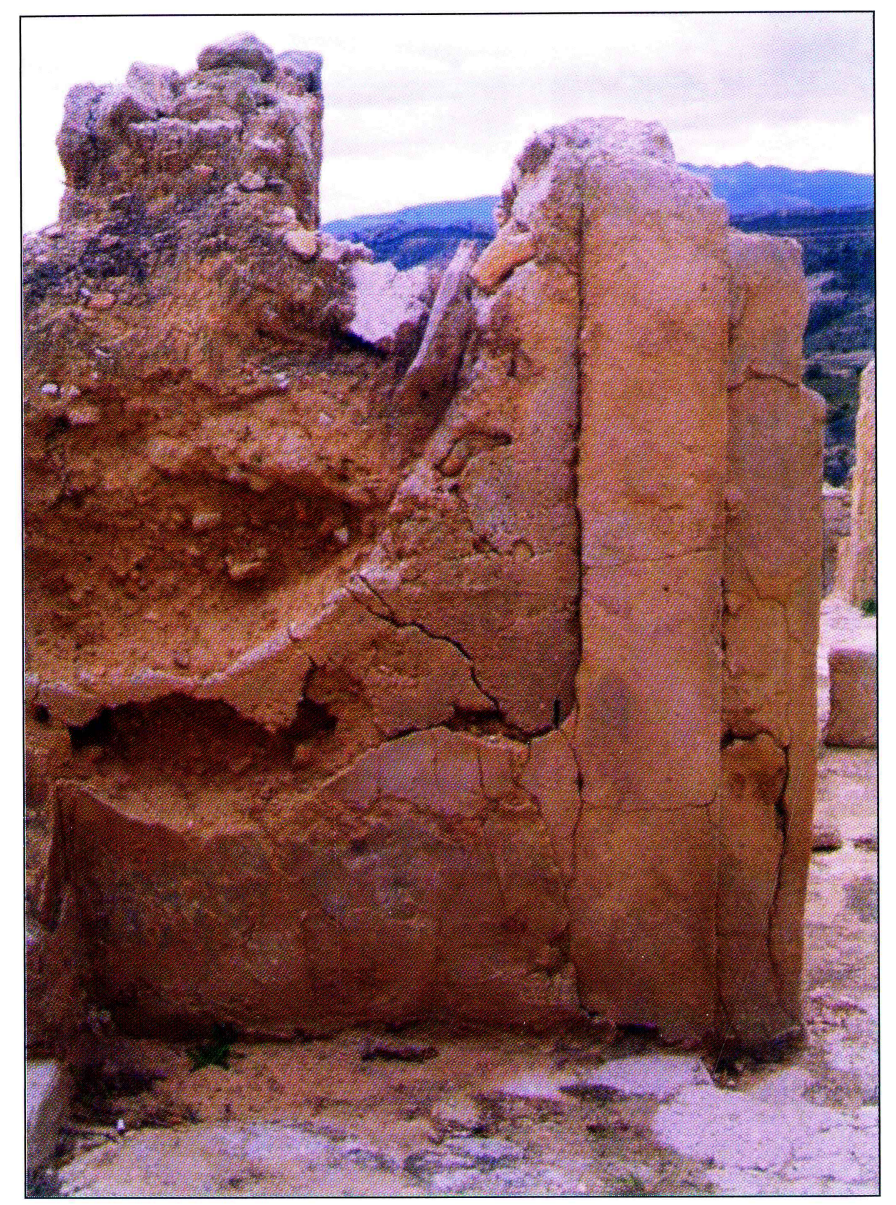

Fig. 41. Siyâsa (Cieza), casa 2. Muro que separaba el salón del patio. Obsérvese la técnica del tapial con brencas, consistente en reforzar con mortero de yeso y piedra la parte de la caja próxima a la jamba mientras que el resto es de tierra

similar fecha del XIII, en un estado de conservación excepcionalmente bueno ${ }^{100}$. Tipológicamente responden al modelo de vivienda de patio central y contaban con una o

${ }^{100}$ Navarro y Jiménez, 2007a. 


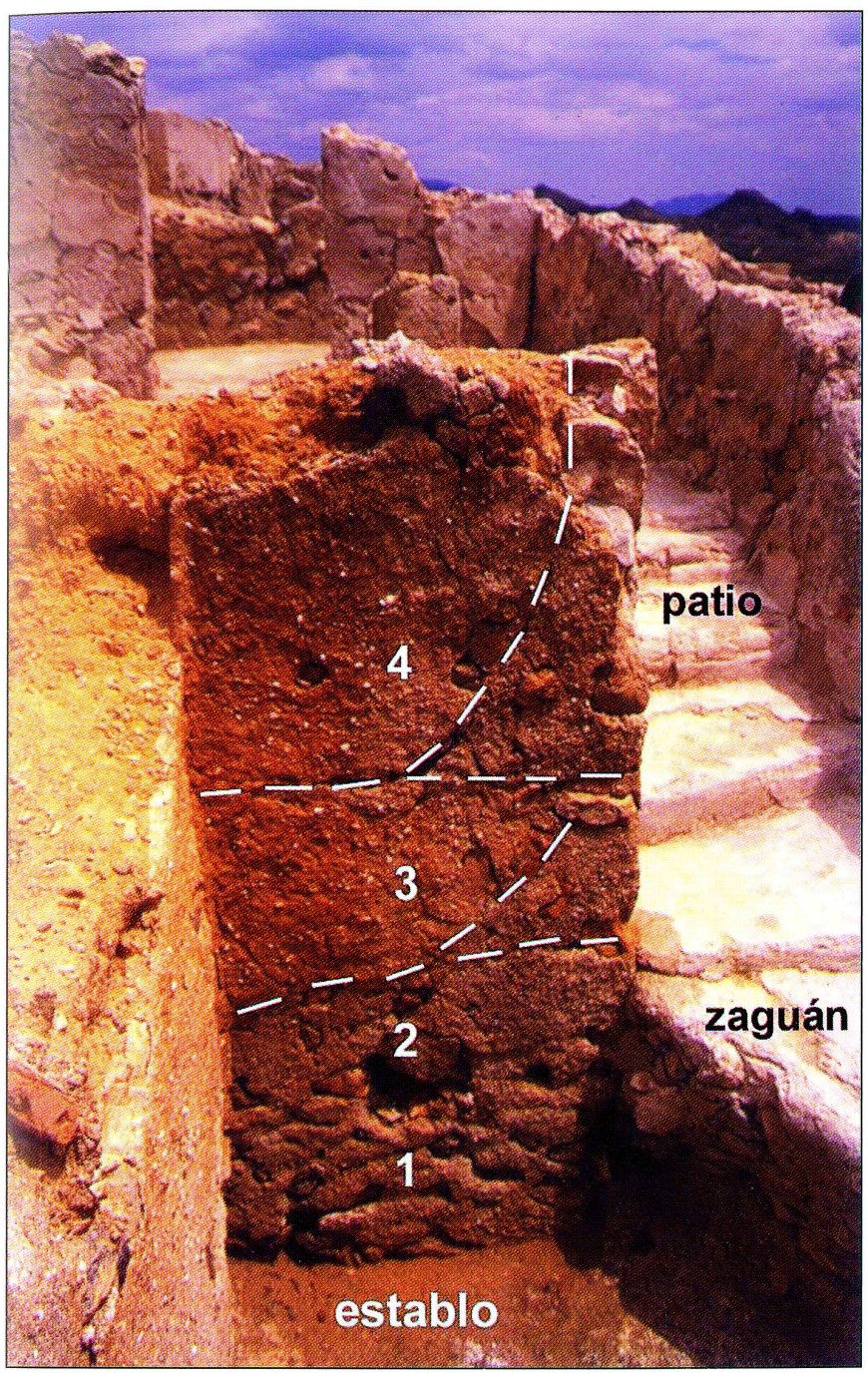

Fig. 42. Siyâsa (Cieza), casa 12. Muro compuesto por una tapia inferior de mampostería sobre la que se sobreponen sucesivas cajas de «tapial con brencas»

más plantas superiores. Se caracterizan también por estar decoradas con abundantes yeserías, mayoritariamente de estilo almohade o protonazarí.

Los muros de carga son de tapial en su totalidad, aunque no suelen ser homogéneos, pues las cajas inferiores presentan habitualmente un material más resistente, a base de mampuestos y yeso ${ }^{101}$, mientras que las superiores son de tierra (figs. 40 y 42). Los zócalos están compuestos normalmente por una tapia de $80 \mathrm{u} 85 \mathrm{~cm}$ que, a veces, constituye también la cimentación. En ocasiones se superponen dos o incluso tres hiladas de tapias de mampuestos si la función que va a tener la pared requiere refuerzo; por

${ }^{101}$ En un breve artículo, Antonio Almagro (1986) da cuenta del frecuente uso del yeso en la arquitectura de tradición andalusí aragonesa, mencionando especialmente su uso en los tapiales.

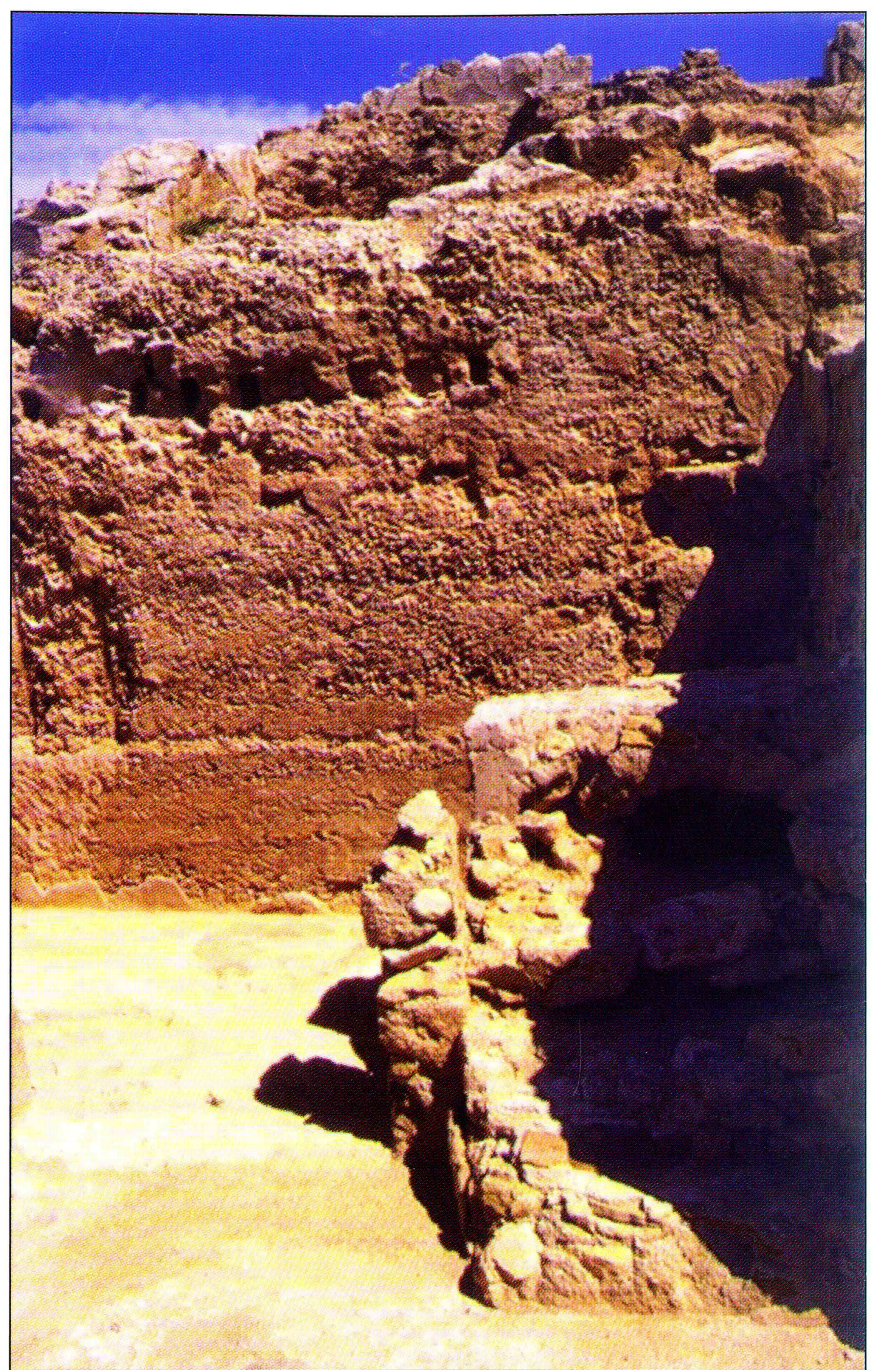

Fig. 43. Siyâsa (Cieza), casa 12. Medianería septentrional, que funciona también como muro de una terraza o parata, razón por la cual está construido en tapial de hormigón, en vez de la tierra habitual

ejemplo, cuando se trata de un muro de contención que separa dos paratas o terrazas, lo que resulta relativamente frecuente en Siyâsa debido a que el poblado, a diferencia de la ciudad de Murcia, se levantaba en una ladera que en ciertos tramos tienen una pendiente muy acusada.

En los alzados de tapial de tierra, las jambas de los vanos son reforzadas mediante rafas de piedra y yeso que forman parte de cada una de las tapias ${ }^{102}$. Éstas se encofran colocando los materiales más resistentes en un extremo de la caja mientras que el resto se rellena con

102 Villanueva (1827, p. 29) explica la necesidad de emplear estos refuerzos: «Si en las tapias ha de haber puertas ó ventanas, es preciso que lleven machos o guarniciones de los mismos materiales (piedra, ladrillo, cascote o adobe), pues con tierra sola son difíciles de hacer y de poca duración, porque los ángulos se desmoronan y arruinan fácilmente con las aguas y hielos". 


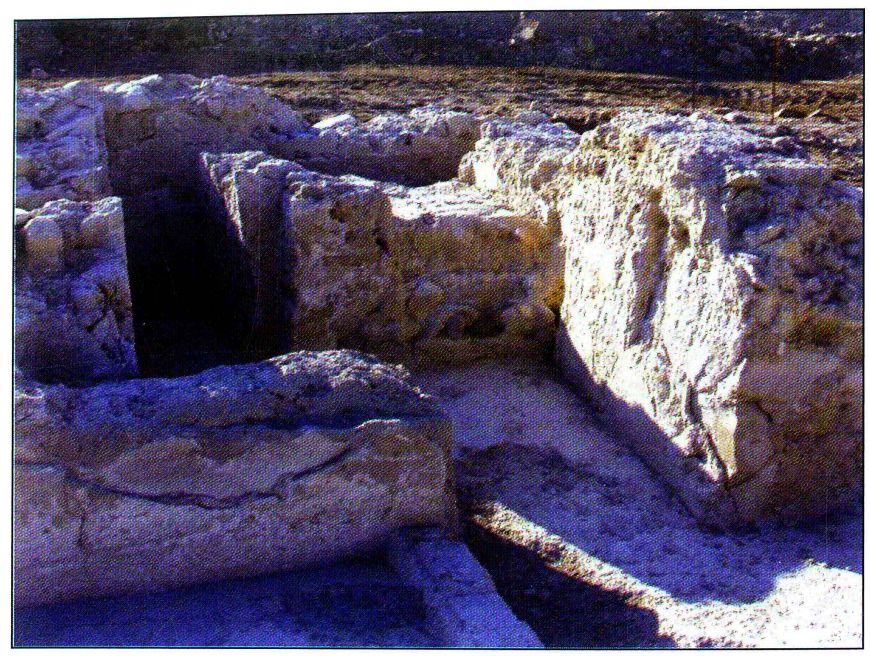

Fig. 44. Mezquita del Centeno (Lorca). Muros de tapial de tierra sobre zócalo de mampostería con yeso en la zona de la escalera

tierra; tal disposición es decreciente, pues en la parte superior las rafas son siempre más estrechas extendiéndose progresivamente hacia abajo (figs. 41 y 42). Se trata del tapial con brencas que ya comentamos en relación al Castillejo $^{103}$. Estas obras, como el resto, eran posteriormente enlucidas.

Aunque en origen todas las paredes maestras eran levantadas de la manera que acabamos de comentar, lo más frecuente es que ciertos muros tengan el aspecto de obras de mampostería debido a las sucesivas reparaciones sufridas. En el caso de muros medianeros, es decir de estructuras compartidas por dos propiedades, difícilmente podían ser rehechas por completo cuando uno de los dos vecinos edificaba ${ }^{104}$, por lo que se optaba por repararlos tramo a tramo y frecuentemente sólo por una de sus caras. Los ejemplos son abundantes, pero uno de los más elocuentes es el muro que separa las casas no 12 y 14 , en el que se ven varias reparaciones realizadas con piedra y yeso, a modo de bataches, que progresivamente han transformado el aspecto primigenio del tapial de tierra. La obra original sólo se conserva en cuatro tramos, cortos y aislados, que podrían hacer pensar al observador no advertido que se trata de una técnica constructiva mixta en la que alternan refuerzos de mampostería y tapias de tierra.

El tapial de hormigón es muy escaso en el caserío ya que ni siquiera en sus defensas se empleó. Se encuentra en los lugares especialmente comprometidos, como en los

${ }^{103}$ Villanueva, 1827, p. 28, lám. IV-2.

104 Un muro medianero sirve de soporte a las vigas de los forjados de las habitaciones que hay a ambos lados; por tanto, su demolición requiere el acuerdo de los copropietarios.

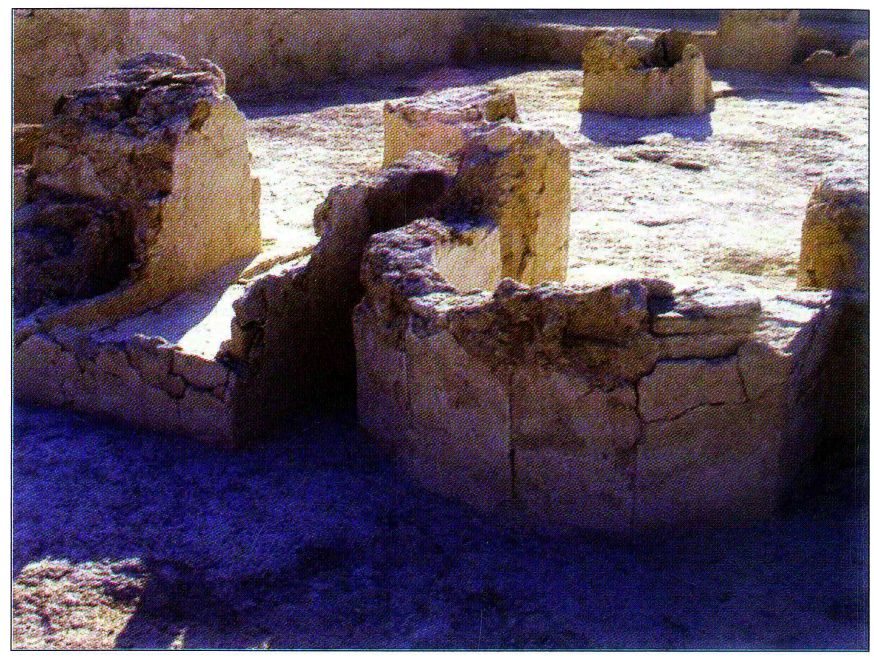

Fig. 45. Mezquita del Centeno (Lorca). Mihrab y nicho del mimbar vistos desde el exterior. Apréciese el empleo de algunos ladrillos en un contexto arquitectónico en el que predomina la mampostería, el yeso y la tierra

muros de contención de algunas paratas, que debían soportar enormes presiones laterales ejercidas por los rellenos (fig. 43), lo que parece indicar que este tipo de paredes fueron las más resistentes que los alarifes siyasíes eran capaces de hacer.

Entre los yacimientos del Sureste peninsular que presentan clara similitud en cuanto a materiales y técnicas constructivas con Siyâsa podemos citar la alquería de Villa Vieja (Calasparra), el hisn de Yakka (Yecla) y la mezquita rural del Cortijo del Centeno; abandonados todos ellos a lo largo del tercer cuarto del s. XIII.

Acerca de la Villa Vieja su excavador comenta lo siguiente: "la mayor parte de las cimentaciones y zócalos están fabricados en mampostería de piedra irregular trabada con yeso o barro, mientras que los alzados fueron de tierra con un fino enlucido de yeso. El tapial de hormigón está escasamente documentado y restringido a cimentaciones sobre las que se elevan muros de mampostería (...) el ladrillo está prácticamente ausente..., tan sólo se han encontrado varios en las alacenas o formando la cubierta de canalillos que desaguaban en los patios» ${ }^{105}$. Al hablar de cimentaciones y zócalos de mampostería el autor da a entender, aunque no lo indique explícitamente, que no se trata de tapiales de mampostería; es posible, en cualquier caso, que el mal estado de conservación de los restos, a diferencia de lo que sucedió en Siyâsa, no permitiera determinar este extremo.

El despoblado de Yakka (Yecla) viene siendo excavado desde hace años y ha sido dado a conocer en varios artículos y un número monográfico de la revista Yakka. De la do-

${ }^{105}$ Pozo, 2000, p. 175. 
cumentación gráfica y las referencias acerca de este tema expuestas por L. Ruiz, se deduce que estamos ante un caso casi idéntico a Siyâsa ${ }^{106}$. Una de las viviendas presenta una particularidad, la abundancia de ladrillo, aunque se trata de material reutilizado procedente del yacimiento romano de Los Torrejones, situado en las proximidades. Del mismo origen son las numerosas plaquetas de mármol (opus sectile), empleadas para pavimentar las plantas altas de cuatro de las casas de Yakka. En este sentido, conviene recordar que, aunque excepcional, también en Siyâsa se ha encontrado algún elemento constructivo romano reutilizado ${ }^{107}$.

La mezquita del Cortijo del Centeno (Lorca) es un pequeño oratorio rural de poco más de $90 \mathrm{~m}^{2}$, que no parece haber estado vinculado a un núcleo de entidad sino que seguramente daba servicio a las alquerías del entorno ${ }^{108}$. Cuenta con tres naves y un espacio rectangular de función dudosa situado tras la qibla. En este edificio encontramos todas las características constructivas que hemos visto en Siyâsa ${ }^{109}$. Los muros de carga del espacio principal están conformados, en cimentación y zócalo, por tapiales de mampostería y yeso. Sobre esta obra se elevaba el alzado de tapial de tierra, todo ello recubierto por gruesas capas de enlucido de yeso (fig. 44). El tapial de hormigón de cal sólo está presente en el muro que delimita el espacio situado al sur de la qibla, que claramente conforma una ampliación de la mezquita original. El empleo de dicho material se justifica por la labor de contención que dicha estructura debió de cumplir, generada por la existencia de una pequeña pendiente; su alzado era de adobe, tal y como se ha podido comprobar en la esquina suroccidental. Apenas se ha utilizado el ladrillo aunque no está del todo ausente: lo encontramos en el mibrab hexagonal (fig. 45), en el tabique frente a la puerta de ingreso y en algunas jambas como refuerzo, y de canto en los tabiques del edículo del almimbar. Como novedad con respecto a Siyâsa hay que destacar el uso de sillarejos de arenisca, presentes en la parte inferior de los pilares

\footnotetext{
${ }^{106}$ Ruiz Molina, 2000, pp. 192-195.

${ }^{107}$ Navarro y Jiménez, 2007a, fig. 17.

${ }^{108}$ Se han publicado varias noticias por parte de su excavadora: Pujante, 2000; id., 2001. También nosotros tratamos este interesante edificio en el capítulo dedicado a la religiosidad islámica en Murcia, del catálogo de la exposición Huellas: (Navarro y Jiménez, 2002, pp.78 - 84).

${ }^{109}$ Acerca de este tema expondremos lo que nosotros hemos podido apreciar en las visitas realizadas al monumento, pues lo publicado al respecto por su excavadora es escueto y poco aclaratorio: "Los muros perimetrales de la dependencia están realizados con mampostería y yeso, hasta el nivel de pavimentación; a partir de la solería, el muro está realizado con tapial de tierra, reduciendo su espesor en altura. Los alzados de adobe se encuentran prácticamente arrasados por la roturación agricola y por la acción de la pendiente, más acusada en este sector del edificio" (Pujante, 2000, p. 76).
}

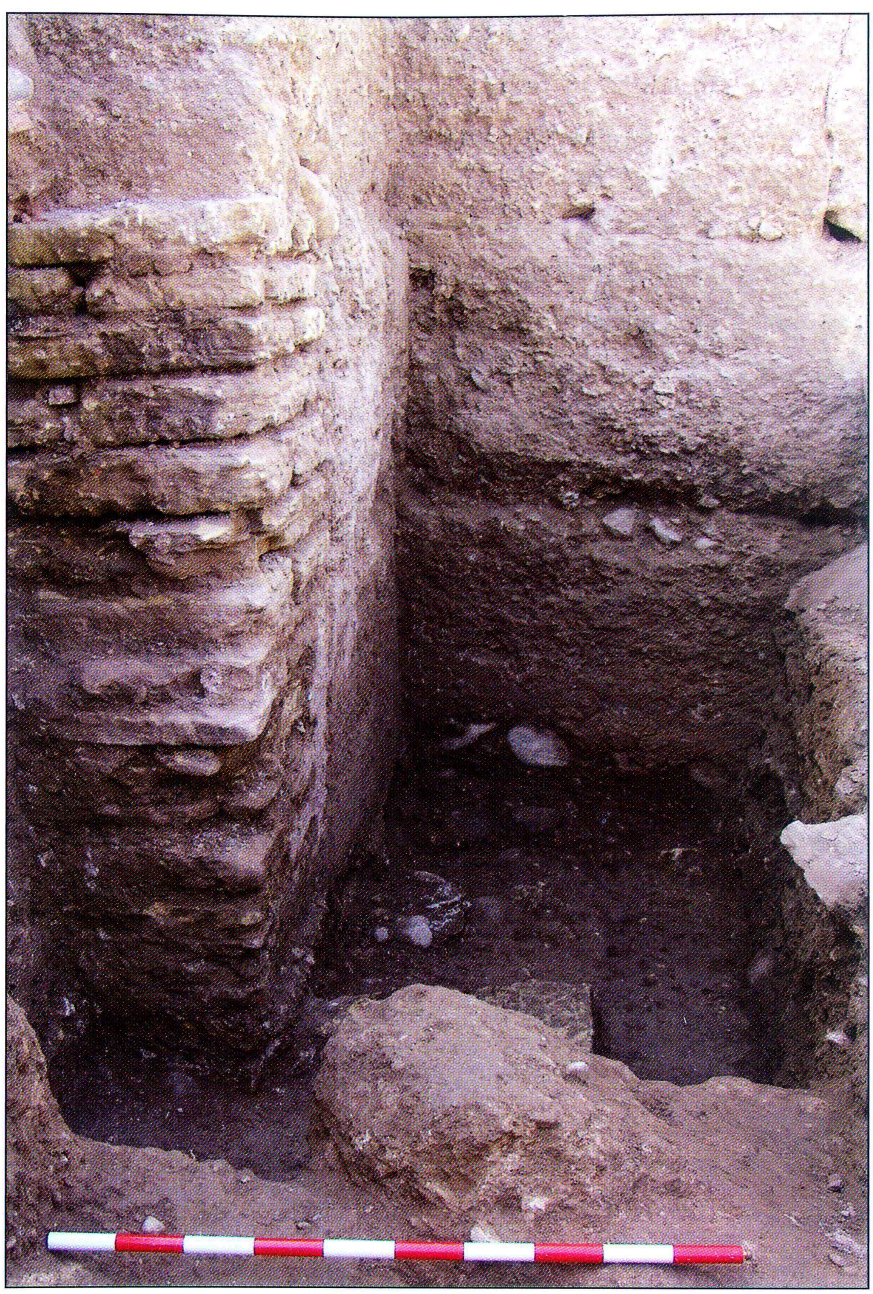

Fig. 46. Muralla de la alcazaba antigua de Granada. Tramo de la cuesta de la Alhacaba, cercano a la puerta de Monaita. Apréciese la obra de tapial de hormigón reforzada en la esquina del torreón con sillarejos reutilizados

hexagonales que separaban las tres naves. Por lo demás, cabe destacar el empleo generalizado del yeso en los pavimentos.

Resumiendo podemos concluir afirmando que tanto las técnicas como los materiales de estos últimos yacimientos se alejan, en gran medida, del panorama urbano que conocemos. La escasez del ladrillo, de la piedra trabajada y del tapial de hormigón, junto al empleo abundante de materiales locales de más fácil elaboración como el adobe, el yeso y los mampuestos extraídos a pie de obra, son característicos de los asentamientos de carácter rural; probablemente, sea la mampostería encofrada con yeso su rasgo más especifico.

\section{CONCLUSIONES}

Las excavaciones arqueológicas de los niveles andalusíes de la ciudad de Murcia han permitido documentar extensiva- 
mente la existencia de dos tipos de aparejos constructivos que se suceden en el tiempo.

El más antiguo se distingue por la presencia abundante de la mampostería y de la piedra labrada. Esta última está presente incluso en los suelos de patios y estancias. Excluidas las construcciones íntegramente hechas con sillería, inexistentes en la ciudad de Murcia, las fábricas de este periodo más habituales tienen zócalos y cimientos de mampostería en hiladas, alternadas con lechos de argamasa de cal, y refuerzos de sillarejos de calcarenita en jambas y otros puntos débiles de los muros; los alzados son de tapial de tierra o de adobes.

El más reciente presenta la novedad de sustituir los basamentos de mampostería por otros de tapial de hormigón de cal, mientras que los antiguos refuerzos de piedra son reemplazados paulatinamente por fábricas de ladrillo; en un primer momento del cambio es frecuente constatar que las jambas de piedra continúan utilizándose, asociadas a los nuevos basamentos de hormigón encofrado.

En general, podemos defender que en la arquitectura de la fase más antigua la piedra labrada está muy presente, mientras que en la fase más reciente será el ladrillo el que ocupe su lugar, sustitución que también afectará a los pavimentos de patios y estancias.

Los dos tipos descritos los hemos documentado especialmente en la arquitectura doméstica, aunque existen evidencias de que el más antiguo también estaba presente en otras construcciones, como rábitas (Guardamar), alhóndigas (Santa Eulalia) ${ }^{110}$, tiendas (Plaza de Belluga) ${ }^{111}$, castillos (Alhama de Murcia, Elche) o baños (San Lorenzo). El segundo está bien representado también en edificios públicos y comerciales, en palacios $y$, por supuesto, en murallas.

La fábrica antigua con lechos de argamasa de cal la hemos fechado, teniendo en cuenta las cerámicas del registro arqueológico y los paralelos bien datados en otros puntos del Sureste y de al-Andalus, en los siglos X-XI. De raíces tardoantiguas, presenta algunos rasgos muy similares a los de la arquitectura cordobesa de la época, sobre todo el uso de los sillarejos de calcarenita en alzados y suelos, por lo que cabría pensar que tenga su origen en los alarifes llegados de esa ciudad, lo que parece por otra parte lógico teniendo en cuenta que Murcia fue fundada ex novo por 'Abd al-Rahmân II para acoger al ejército y la administración emiral y consolidar así el control de la provincia o cora de Tudmîr. La fábrica más reciente se extiende entre

\footnotetext{
${ }^{110}$ Jiménez y Navarro, 2001, pp. 147 y 148

${ }^{111}$ Jiménez y Navarro, 2001, pp. 146 y 147.
}

los siglos XII y la conquista cristiana de mediados del siglo XIII; esta fecha ante quem es convencional, puesto que nuestro estudio no se ocupa del periodo castellano. No obstante, podemos adelantar que existen pruebas arqueológicas y textuales de que siguió empleándose en construcciones cristianas, conviviendo con fábricas góticas de sillería utilizadas en ciertos edificios singulares.

No es sencillo precisar la fecha en que se produjo la sustitución de aparejos aunque, teniendo en cuenta la información estratigráfica de que disponemos y los pocos datos que proporcionan algunos yacimientos fuera de Murcia, parece que aconteció en época almorávide, a finales del siglo XI o principios del XII. Así por ejemplo, ambos aparejos están presentes en edificios oficiales almorávides: el primero en construcciones de Yûsuf Ibn Tâsufîn y el segundo en obras de su hijo 'Alî.

Las causas que explican la generalización del ladrillo a partir de este momento no están claras. Este material fue extensivamente empleado en época romana, está presente en las bóvedas de las iglesias visigodas y sólo con la conquista musulmana parece haber decaído significativamente su uso. Las razones que habitualmente se alegan para fundamentar su recuperación en la fase indicada son, fundamentalmente, de naturaleza social y defienden que se debe a la existencia de una importante demanda de materiales constructivos ocasionada por la bien acreditada expansión urbana de ese momento. Sin embargo, parece improbable que las causas sean únicamente aquéllas ligadas al desarrollo de los núcleos de población, pues el fenómeno más destacado en este sentido fue el del enorme desarrollo de la Córdoba califal, en la cual la presencia del ladrillo es prácticamente anecdótica ${ }^{12}$. El caso cordobés evidencia que debe de existir algún otro factor desencadenador de la generalización del ladrillo en detrimento de la piedra, tal vez vinculado a los continuos influjos orientales $\mathrm{o}^{113}$, incluso, a la revitalización a partir de Toledo de tradiciones visigodas que allí se habrían mantenido, como podrían hacer pensar

\footnotetext{
${ }^{112}$ En relación con la presencia del ladrillo en el alcázar de Madînat al-Zahrâ' se dice lo siguiente: «Salvo en la construcción de los elementos relacionados con el fuego, como los hornos e hipocaustos de los dos baños excavados y las bóvedas de los hornos de cocina de las viviendas 9 y 12, las estructuras de ladrillo son excepcionales" (Vallejo, 2010, pp. 318 y 319).

${ }^{113}$ En términos más generales, Gonzalo Borrás considera que: «El uso de estos materiales y técnicas en el arte musulmán es asimismo el resultado de un lento proceso de formación artística, que cristaliza en el siglo XI durante el periodo abasi; por su lado el arte hispanomusulmán, con su particular evolución artística, llegará en el siglo XI, durante la época de taifas, a una profundización artística, configurándose entonces el sistema de trabajo que implica el uso de los materiales y técnicas a los que nos referimos, y que se desarrollará posteriormente en las sucesivas etapas del arte hispanomusulmán —almorávide, almohade, nazarí y en el arte mudéjar." (Borrás, 1990, pp. 145 y 146).
} 
las ya mencionas mezquitas del Cristo de la Luz y Tornerías. Evidementemente, esta es una de las cuestiones que quedan planteadas a la espera de que en un futuro, cuando se disponga de más información, se pueda dar respuesta.

En cuanto a la generalización del tapial de hormigón de cal, con más piedra (calicanto) o con menos, los datos que manejamos son todavía escasos y pendientes de contrastar; no obstante, creemos que este tipo de fábrica pudo comenzar a emplearse en construcciones que requerían mayor consistencia, como son las de tipo militar. La prueba de que el tapial de hormigón era más resistente y de uso más selectivo la encontramos, por ejemplo, en el uso que se le da en el yacimiento de Siyâsa, en donde predominan las tapias de mampostería y yeso excepto en algunos muros de contención especialmente comprometidos, que se realizan en hormigón (fig. 43). Así, en la fortaleza estatal de Onda (Castellón), que actualmente estamos excavando, hemos comprobado que su muralla está hecha de tapial de hormigón con abundante piedra en las cajas inferiores, y calicastrado en las superiores, mientras que los muros del edificio que hay en su interior están construidos con zócalos de mampostería y alzados de tierra. Es decir, siendo contemporáneos, la muralla con sus torres semicirculares estarían construidas con el aparejo de nuestra fase reciente y los interiores con el de la antigua. Como la construcción de Onda la venimos fechando en el siglo XI, creemos que se debe contemplar la hipótesis de que el aparejo que hemos denominado como reciente comenzara a utilizarse ya en el siglo XI en murallas y fortalezas ${ }^{114}$, para generalizarse a fines de esa centuria $o$ comienzos de la siguiente en las demás arquitecturas, incluida la residencial.

El estado de la investigación sobre el tema que nos ocupa se encuentra, al menos en el área murciana, en un estado prácticamente embrionario, por lo que actualmente nos movemos en unas horquillas cronológicas muy amplias que apenas permiten llegar a conclusiones de tipo histórico; téngase en cuenta que sólo con el examen de los aparejos no podemos aún distinguir la arquitectura del siglo X de la del XI, ni la de principios del XII de la del momento de la conquista castellana de mediados del XIII. Para avanzar en los estudios es necesario continuar aportando ejemplos bien fechados que permitan poco a poco completar el panorama cronotipológico de las técnicas y

\footnotetext{
${ }^{114}$ Coincidimos, por tanto, con Graciani y Tabales, quienes explican que "Las fábricas de tapial más antiguas detectadas en la Provincia (se refieren a Sevilla) corresponden a época taifa, momento en que éstas comenzaron a proliferar en todo Al Andalus, especialmente en la edificación militar.» (Graciani y Tabales, 2008, p. 138).
}

materiales constructivos en el Sureste, como fue el caso, por ejemplo, de la rábita de Guardamar; en esta línea de precisión cronológica, hemos aportado en el presente trabajo un grupo significativo de edificios bien datados, los mardanîšíes (1147-1172) y el palacio hudí de Santa Clara (1228-1238).

Finalmente, hemos comprobado que la arquitectura existente en el medio rural presenta diferencias significativas con la urbana coetánea. A esta conclusión hemos llegado al comparar los tipos de fábrica de los edificios de la fase reciente de Murcia con los de la misma época de Siyâsa y con algunos otros ejemplos localizados en yacimientos de su entorno. La rural se caracteriza por el aprovechamiento intensivo de los materiales de su entorno más inmediato y la ausencia de los que han de ser transportados desde una cierta distancia, así como la inexistencia, o presencia testimonial, de materiales que requieren de un artesanado especializado para su elaboración, como es el caso de la cantería, del ladrillo y de la cal, técnicas y materiales estos últimos muy presentes en el medio urbano.

\section{Bibliografía}

Acién Almansa, M. y Vallejo Triano, A., 1998, «Urbanismo y Estado islámico: de Corduba a Qurtuba-Madînat al-Zahrâ'", Genèse de la ville islamique en alAndalus et au Maghreb occidental, Madrid, pp. 107-136.

Acién, M. y Cressier, P., 2009, «Fortalezas dinásticas del Marruecos medieval: aspectos constructivos", Monografias del Conjunto Monumental de la Alcazaba. $N^{o}$ 2. Construir en al-Andalus, Almería, pp. 173-203.

Al-Himyarî, 1938, La Péninsule Ibérique au Moyen Âge d'après le "Kitâb ar-rawd al-mitâr fi habar al-aktâr» d'Ibn 'Abd al-Mun'im al-Himyarî, trad. É. LévyProvençal, Leiden.

Al-Hulal al-Mawsiyya, 1952, (crónica anónima), ed. y trad. A. Huici Miranda, Colección de Crónicas Árabes de la Reconquista, t. I, Tetuán.

Almagro Gorbea, A., 1986, "El yeso, material mudéjar», Actas del III Simposio Internacional de Mudejarismo (Teruel, 20-22 de septiembre de 1984), Teruel, pp. 453-457.

Almagro Gorbea, A., 2001, «Un aspecto constructivo de las bóvedas en alAndalus», Al-Qantara, XXII, 1, pp. 147-170.

Almagro Gorbea, A., 2008, "La puerta califal del castillo de Gormaz», Arqueología de la Arquitectura, 5, pp. 55-77.

Andreu Martínez, M. A., 1997, «Restos de viviendas islámicas en la calle Polo de Medina de Murcia», Memorias de Arqueología, 6 (1991), pp. 385-391.

Arnold, F., Canto, A. y Vallejo, A., 2009, "Das islasmische Landgut arRumanîya bei Córdoba. Vorbericht einer Bauafnahme», Madrider Mitteilungen, 50, pp. 503-523.

Azuar, R., Bevia, M., Borrego Colomer, M. y Saranova Zozaya, R., 1988/90, «La rábita de Guardamar (Alicante): su arquitectura», Cuadernos de Madînat alZahrâ', 2, pp. 55-83.

Azuar, R., 1989, La rábita califal de las dunas de Guardamar (Alicante), Alicante.

- 1995, "Las técnicas constructivas en Al-Andalus. El origen de la sillería y del hormigón de tapial», $V$ semana de estudios medievales, pp. 121-142.

- 2004a, El ribat califal. Excavaciones e investigaciones (1984-1992), Madrid.

- 2004b, "Las técnicas constructivas y la fortificación almohade en al-Andalus», Los almohades. Su patrimonio arquitectónico y arqueológico en el Sur de alAndalus, Sevilla, pp. 57-74.

- 2005, "Las técnicas constructivas en la formación de Al-Andalus», Arqueología de la Arquitectura, 4, pp. 149-160. 
- 2009, «La construcción de Al-Andalus», Construir en Al-Andalus, Monografías del Conjunto Monumental de la Alcazaba, no 2, Almería, pp. 11-37.

Baños Serrano J. y Jiménez Castillo, P., 2005, «Excavaciones en el Castillo de Alhama. Proyecto Castrum», XVI Jornadas de Patrimonio Histórico: intervenciones en el patrimonio arquitectónico, arqueológico y etnográfico de la región de Murcia, Murcia, pp. 321-322.

Bazzana, A., 1992, Maisons d'al Andalus. Habitat Médiéval et Structures du peuplement dans l'Espagne orientale, 2 vols., Madrid.

Bernabé Guillamón, M., 1994, «Dos viviendas musulmanas excavadas en Murcia. La calle Raimundo de los Reyes (4-6)», Verdolay, 6, pp. 133-142.

Bernabé Guillamón, M. y López Martínez, J. D., 1993, El Palacio Islámico de la calle Fuensanta. Murcia, Murcia.

Bernal Pascual, F. y Calabuig Jordán, R., 1995, «Restos de una vivienda islámica en la C/ San Nicolás no 27 (Murcia)», Memorias de Arqueología, 3 (19871988), pp. 319-328.

Bernal Pascual, F. y Jiménez Castillo, P., 1993, «Excavaciones arqueológicas de urgencia: C/. Montijo 8. Memoria Preliminar», Memorias de Arqueología, 4 (1989), pp. 389-402.

Borrás Gualís, G. M., 1990, El arte mudéjar, Teruel, 1990.

Brunschvig, R., 1947, "Urbanisme médieval et droit musulman», Revue des Études Islamiques, XV, pp. 127-155, París.

Camacho Cruz, C., 2008, «Estudio sobre pavimentación en la vivienda del siglo X», Arte, Arqueologia e Historia, 15, pp. 221-235.

- 2010, «La almunia en la Ronda Oeste. Un hito en la arqueología cordobesa», Arte, Arqueología e Historia, 17, pp. 173-181.

Casal García, Mª T., 2008, «Características generales del urbanismo cordobés de la primera etapa emiral: el arrabal de Saqunda", Anejos de Anales de Arqueologia Cordobesa, 1, pp. 95-120.

Castillo Galdeano, F. y Martínez Madrid, R., 1990, «La vivienda hispanomusulmana en Bayyâna-Pechina (Almería)», La casa hispano-musulmana. Aportaciones de la arqueología, Granada, pp. 111-127.

Castro del Río, E., 2001, «La arquitectura doméstica en los arrabales de la Córdoba califal: la zona arqueológica de Cercadilla», Actas de las II Jornadas Cordobesas de Arqueología Andaluza. Arqueologia de al-Andalus: "Los Palacios Islámicos», en Anales de Arqueología Cordobesa, 12, pp. 241-281.

- 2005, El arrabal de época califal de la zona arqueológica de Cercadilla: la arquitectura doméstica, Córdoba.

Doualatli, A., 1976, Tunis sous les hafsides, Tunis.

Ewert, C., Wisshak, J. P., 1984, Forschungen zur almohadischen Moschee. Lfg.2, die Mosche von Tinmal (Marokko), Madrider Beiträge, Main-sur-le-Rhin, Ph. Von Zabern.

Fernández González, F. V. y López Martínez, J. D., 1993, «Restos de viviendas islámicas en la calle Frenería de Murcia», Memorias de Arqueología, 4 (1989), pp. 341-350.

Font, F. e Hidalgo, P., 2009, Arquitecturas de tapia, Castellón.

García-Bellido y García de Diego, J., 1999, Coranomía. Los universales de la urbanistica. Estudio sobre las estructuras generativas en las ciencias del territorio. Tesis Doctoral dirigida por el Dr. Luis Moya González, Madrid: Univ. Politécnica de Madrid.

Giralt Balagueró, J., 1998, «La génesis de los espacios urbanos andalusíes (siglos VIII-X): Tortosa, Lleida y Balaguer», El Islam y Cataluña, Barcelona, pp. 137165.

González Escudero, A., «Las técnicas constructivas de Madinat Ilbira», Arqueologia Medieval.com, http://www.arqueologiamedieval.com/articulos/104l, 24/ 09/08.

Graciani García, A., 2009, «La Técnica del Tapial en Andalucía Occidental», Construir en al-Andalus, Monografías del Conjunto Monumental de la Alcazaba, no 2, Almería, pp. 111-140.

Graciani García, A. y Tabales Rodríguez, M. A., 2008, «El tapial en el área sevillana. Avance cronotipológico estructural", Arqueología de la Arquitectura, 5, pp. 135-158.

Guillermo Martínez, M., 1998, «La casa islámica y el horno bajomedieval de calle de La Manga, 4 (Murcia)», Memorias de Arqueologia, 7 (1992), pp. 451 475.

Gutiérrez González, F. J., 2006, La excavación arqueológica del paseo de la Independencia de Zaragoza, Zaragoza.
Gutiérrez Lloret, S., 2000, «El espacio doméstico altomedieval del Tolmo de Minateda (Hellín, Albàcete), entre el ámbito urbano y el rural», Actas del Coloquio Castrum 6. Maisons et espaces domestiques dans le monde méditerranéen au Moyen Âge, pp. 151-164.

Gutiérrez Lloret, S., Martí Oltra, J. y Menéndez Fueyo, J. L., 2010, «Apunts sobre l'edifici del Castellar d'Elx. Arquitectura d'una construcció singular», El Castellar d'Elx. L'origen de la ciutat medieval, Elche, pp. 29-34.

Ibn Abî Zar', 1964, Rawd al-qirtas, traducido y anotado por Ambrosio Huici Miranda, Valencia.

Ibn 'Idârî al-Marrakusî, 1963, Al-Bayân al-Mugrib: nuevos fragmentos almorávides $y$ almohades, traducidos y anotados por A. Huici Miranda, Valencia.

Ibn Hawqal, 1842, Description de l'Afrique, trad. M. G. de Slane, París.

Jiménez Castillo, P., 1993, «Excavación arqueológica de un alfar en el arrabal de la ciudad de Murcian, Memorias de Arqueologia, 4 (1989), pp. 427-432.

Jiménez Castillo, P. y Navarro Palazón, J., 1997, Platería 14. Sobre cuatro casas andalusies y su evolución (siglos $X$-XIII), Murcia.

- 2000, "Génesis y evolución urbana de Murcia en la Edad Media», Murcia ayer $y$ hoy, Murcia, pp. 40-130.

- 2001, «Murcia omeya «, El esplendor de los Omeyas cordobeses: la civilización musulmana de Europa Occidental: Estudios, Ma Jesús Viguera y Concepción Castillo (coors.), Granada: El Legado Andalusí, pp. 132-151.

- 2002a, «Casas y tiendas en la Murcia andalusí. Excavación en el solar municipal de plaza de Belluga», Memorias de Arqueología, 10 (1995), pp. 489-532.

- 2002b, «Casas califales en Murcia. Excavación en un solar de calles Puxmarina-Zarandona", Memorias de Arqueología. Región de Murcia, 11 (1996), pp. 469-500.

Jiménez Castillo, P., Navarro Palazón, J. y Thiriot, J., 2005, «Taller de vidrio y casas andalusíes en Murcia. La excavación arqueológica del casón de Puxmarina", Memorias de Arqueología. Región de Murcia, 12 (1997), pp. 419-458.

Jiménez Castillo, P. y Navarro Palazón, J. y Sánchez González, Ma J., 2006, «Sobre la formación del zoco: la excavación del solar de calle San Pedro de Murcia", Memorias de Arqueología. Región de Murcia, 14 (1999), pp. 421-458.

Lévy-Provençal, E., 1938, La péninsule ibérique au moyen-age d’aprés le Kitâb arRadw al-Mitar, Leiden.

López Martínez, J. D., 1993, «El conjunto arquitectónico de calle Selgas no 1 (Murcia)», Memorias de Arqueologia, 4 (1989), pp. 417-426.

López Martínez, J. D. y Sánchez Pravia, J. A., 2004, «Urbanismo de la ciudad de Murcia en época musulmana. Estudio de nueve viviendas y una calle», Memorias de Arqueologia. Región de Murcia, 12 (1997), pp. 545-570.

López Martínez, F. J., «Tapias y tapiales», Loggia, 8 (1999), pp. 74-89.

Macías, S., 1996, Mértola Islâmica. Estudo Histórico-Arqueológico do Bairro da Alcáçova (séculos XII-XIII), Mértola.

Mahfoudh, F., (en prensa), «Urbanisme médiévale en Ifriqiya orientale», Actas del Congreso "La medina andalusí. Estado actual de las investigaciones y de la gestión arqueológica de las medinas occidentales», Granada 8, 9 y 10 de noviembre de 2004

Manzano Martínez, J., 1995, «Trabajos arqueológicos en el subsuelo de la Plaza de Europa (antiguo Garaje Villar). Ciudad de Murcia», Memorias de Arqueologia, 3 (1987-88), pp. 354-397.

Manzano Martínez, J., López Martínez, J. D. y Fernández González, F. V., 1989, "Una vivienda islámica en la calle Pinares de Murcia», Miscelánea Medieval Murciana, V, pp. 215-244.

- 1993, "Una vivienda islámica en la calle Pinares de Murcia», Memorias de Arqueología, 4 (1989), pp. 404-416.

Marçais, G., 1954, La arquitectura musulmana de Occidente, París.

Martí, J. y Pascual, J., 2000, «El desarrollo urbano de Madîna Balansiya hasta el final del califato", en L. Cara (ed.) Ciudad y territorio en al-Andalus, Granada, pp. 500-536.

Mateos Cruz, P. y Alba Calzado, M., 2000, «De Emerita Augusta a Marida», en L. Caballero y P. Mateos (eds.) Visigodos y Omeyas. Un debate entre la Antigüedad Tardía y la Alta Edad Media, Anejos de Archivo Español de Arqueología, XXIII, Madrid, pp. 143-168.

Menéndez Pidal, R., 1935, Primera Crónica General de España, Madrid.

Meunié, J., Terrasse, H. y Deverdun, G., 1952, Recherches archéologiques à Marrakech, Paris.

Montejo Córdoba, A. J., 1999, «El pabellón de abluciones oriental de la 
mezquita aljama de Córdoba correspondiente a la ampliación de Almanzor», Cuadernos de Madînat al-Zahrâ', 4, pp. 209-231.

Muñoz López, F., 1999a «Sobre la evolución de una manzana de casas andalusíes", Memorias de Arqueología, 8 (1993), pp. 415-436.

- 1999b, "Casas musulmanas en C/. Santa Isabel, no 5 de Murcia», Memorias de Arqueología, 9 (1994), pp. 601-608.

Muñoz López, F. y Jiménez Castillo, P., 2004, «Casas, hornos y muralla de la Murcia medieval, en un solar de calle Sagasta esquina con Aistor», Memorias de Arqueología. Región de Murcia, 12 (1997), pp. 503-532.

- 2005, «Expansión y regresión urbana en el arrabal del Arrixaca de Murcia Excavación en calle Serrano no 4", Memorias de Arqueología. Región de Murcia, 13 (1998), pp. 459-477.

Navarro Palazón, J., 1986a, La cerámica esgrafiada andalusi de Murcia / La céramique hispano-arabe à décor esgrafié de Murcie, Publications de la Casa de Velázquez, Serie Études et Documents, II, Madrid.

- 1986b, La cerámica islámica en Murcia. I Catálogo, Murcia.

- 1990a, "La casa andalusí en Siyâsa: ensayo de una clasificación tipológica», La casa hispano-musulmana. Aportaciones de la arqueología, Granada, pp. $177-$ 198.

- 1990b, "Los materiales islámicos del alfar antiguo de San Nicolás de Murcia», Fours de potiers et «testares» médievaux en Méditerranée Occidentale, Madrid, pp. 29-44.

- 1991a, "Un ejemplo de vivienda urbana andalusí: la casa n 6 de Siyâsa», Archéologie Islamique, II, pp. 97-125.

- 1991b, Una casa islámica en Murcia. Estudio de su ajuar (siglo XIII), Murcia.

- 1995, "Un palacio protonazarí en la Murcia del siglo XIII: Al-Qasr al-Sagim, Casas y Palacios de Al-Andalus. Siglos XII y XIII, Barcelona-Madrid, pp. 177205.

- 1998, "La Dâr as-Sugrà de Murcia. Un palacio andalusí del siglo XII», Colloque international d'archéologie islamique, IFAO, El Cairo, 3-7 febrero 1993, El Cairo, pp. 97-139.

- 2005, "Sobre palacios andalusíes (Siglos XII-XIV)», Vivir en palacio en la Edad Media. Siglos XII-XV, Segovia: Caja Segovia, pp. 111-144. Un año antes se publicaron una edición en catalán y otra en francés.

Navarro Palazón, J. y Estall y Poles, V., 2010, "La alcazaba de Onda», El legado andalusí, 44, año XI, $4^{\circ}$ trimestre, pp. 78-87.

Navarro Palazón, J. y Jiménez Castillo, P., 1995a, «El Castillejo de Monteagudo: Qasr Ibn Sa'd», Casas y Palacios de Al-Andalus. Siglos XII-XIII, Barcelona, pp. 63104.

- 1995b, "Arquitectura mardanîsí, La arquitectura del Islam occidental, Barcelona, pp. 117-137.

- 1995c, "La decoración almohade en la arquitectura doméstica: La casa no 10 de Siyâsa», Casas y Palacios de Al-Andalus. Siglos XII-XIII, Barcelona, pp. $117-$ 137.

- 1995d, "La producción cerámica medieval de Murcia», en C. M. Gerrard, A Gutiérrez y A. Vince (eds.) Spanish medievals ceramics in Spain and the British Isles, British Archaeological Reports International Series 610, Oxford, pp. 183-212.

- 1996, "Estudio sobre once casas de Siyâsa», Memorias de Arqueología, 5 (1990), pp. 525-595.

- 2000, "Siyâsa: un ejemplo de arquitectura en yeso", Historia de las técnicas constructivas en España, Tomás Abad et al. (eds.), Madrid, pp. 129-132.

- 2002, «Religiosidad y creencias en la Murcia musulmana. Testimonios arqueológicos de una cultura oriental", en Huellas. Catedral de Murcia. Exposición 2002 (23 de enero - 22 de julio), Murcia, pp. 58-87.

- 2005, «La yesería en época almohade», Los almohades: problemas y perspectivas, vol. I., Madrid, pp. 249-303.

- 2007a, Siyâsa. Estudio arqueológico del despoblado andalusí (ss. XI-XIII), Murcia.

- 2007b, "Algunas reflexiones sobre el urbanismo islámico», Artigrama, Revista del Departamento de $\mathrm{H}^{\text {a }}$ del Arte de la Univ. de Zaragoza, 22, pp. 259-298.

- 2007c, Las ciudades de Alandalús. Nuevas perspectivas, Zaragoza.

- 2009, "Casas y palacios de la Murcia andalusí a la llegada de Alfonso X", Alfonso X y su época. Catálogo de la exposición celebrada en Murcia, Murcia, pp. 705-720.

- 2011, «El Alcázar Menor de Murcia en el siglo XIII. Reconstrucción de una finca palatina andalusín, La ciudad medieval. De la casa principal al palacio urbano, Toledo, pp. 145-188.

- En prensa, "La partición de fincas como síntoma de saturación en la ciudad andalusí: los ejemplo de Siyasa y Murcia», Cristãos e Muçulmanos na Idade Média Peninsular - Encontros e Desencontros, Rosa Varela (ed.), Universidad Nova de Lisboa.

Pascual, J. y Martí, J., 2001, «El recinto fortificado de la Valencia musulmana», Actas del simposio internacional "Mil anos de fortificaçôes na Península Ibérica e no Magreb (500-1500)», Palmela.

Ponce García, J. y Martínez Rodríguez, A. y Pérez Richard, E. S., 2005, «Restos de un "palacio» islámico en el Convento de Nuestra Señora La Real de Las Huertas (Lorca, Murcia)», Alberca: Revista de la Asociación de Amigos del Museo Arqueológico de Lorca, 3, pp. 85-106.

Ponce García, J. y Martínez Rodríguez, A., 2008, «El palacio islámico hallado en el convento de Nuestra Señora la Real de las Huertas (Lorca, Murcia)», Las artes y las ciencias en el Occidente musulmán, Murcia, pp. 189-201.

Pozo Martínez, I., 1999, "Arquitectura y arqueología islámicas en el monasterios de Santa Clara la Real (Murcia)», Paraísos perdidos. Patios y claustros, Murcia, pp. 53-104.

- 2000, "La alquería islámica de Villa Vieja (Calasparra, Murcia)», Castrum 6.Maisons et espaces domestiques dans le monde Méditerranéen au Moyen Àge, Roma-Madrid, pp. 165-175.

Pozo Martínez, I., Robles Fernández, A. y Navarro Santa Cruz, E., 2007a, «Arquitectura y artes decorativas del siglo XII: el alcázar menor de Santa Clara, Murcia (Dâr as-Sugra)», Las artes y las ciencias en el Occidente musulmán, Murcia, pp. 234-250.

- 2007b., "Arquitectura y artes decorativas de época tardoalmohade: el palacio islámico de Santa Clara (Qasr as-Sagîr)», Las artes y las ciencias en el Occidente musulmán, Murcia, pp. 280-301.

Pujante Martínez, A., 1999, «Excavación arqueológica de urgencia del solar situado en la calle Marengo no 12 de Murcia», Memorias de Arqueología, 8 (1993), pp. 441-453.

- 2000, "Actuaciones arqueológicas en la Presa de Puentes. Lorca (Murcia)», Resúmenes de las XI Jornadas de Patrimonio Histórico y Arqueología Regional, Murcia, pp. 58-61.

- 2001, «La mezquita rural de la alquería del cortijo del Centeno. Lorca (Murcia)", Revista de Arqueología, XXI, pp. 42-49.

Ramírez Águila, J. A., 2004, «Excavaciones en dos solares unificados entre las calles Andrés Baquero, Pinares y callejón de los Peligros de Murcia", Memorias de Arqueología. Región de Murcia, 12 (1997), pp. 571-598.

Ramírez Águila, J. A. y Martínez López, J. A., 1996, «Murcia: una ciudad del siglo XI», Verdolay, 8, pp. 57-75.

- 1999, "Introducción al urbanismo de la Murcia islámica a través de una intervención de urgencia en los solares número 31, 33 y 35 de la calle Platería (junio-octubre, 1994)", Memorias de Arqueología, 9 (1994), pp. 547-569.

Robles Fernández, A. y Navarro Santa Cruz, E., 1999, «Arquitectura doméstica andalusí y alfarería mudéjar en el Arrabal de la Arrixaca. Memoria de la intervención realizada en un solar de la Plaza Yesqueros-Calle Toro (Murcia)», Memorias de Arqueología, 9 (1994), pp. 571-600.

Ruiz Molina, L., 2000, Hisn Yakka. Un castillo rural de Sharq al-Andalus. Siglos XI al XIII. Excavaciones Arqueológicas en el Cerro del Castillo de Yecla (19901999). Yakka. Revista de Estudios Yeclanos, 10, nº monográfico.

Ruiz Parra, I., 1996, "Excavaciones arqueológicas en el solar de la C/. Conde Valle de San Juan, esquina C/. Pascual de Murcia», Memorias de Arqueología, 5 (1990), pp. 415-434.

- 1999, «Excavaciones arqueológicas en el solar de la calle Mariano Girada n 1 y 3 (Murcia)», Memorias de Arqueología, 8 (1993), pp. 455-460.

Sánchez Pravia, J. A., García Blánquez, L. A., 2007, «Fulgor en el alcázar musulmán de Murcia. El conjunto religioso-funerario de San Juan de Dios», Las artes y las ciencias en el Occidente musulmán, Murcia, pp. 234-250.

Tabales Rodríguez, M. A., 2000, "Algunas reflexiones sobre fábricas y cimentaciones sevillanas en el período islámico», Actas del III Congreso Nacional de Historia de la Construcción, vol. II, pp. 1077-1089.

- 1999, "Algunas notas sobre fábricas murarias almohades de Sevilla», Los almohades. Su patrimonio arquitectónico y arqueológico en el Sur de al-Andalus, Sevilla, pp. 75-90. 
Tahiri, A., 1998, "Problemas de una reconstrucción urbana en al-Andalus: el ejemplo de la Sevilla 'abbâdì, Genèse de la ville islamique en al-Andalus et au Maghreb occidental, Madrid, pp. 219-227.

Terrasse, H., 1968, La Mosquée al-Qaraouiyin a Fès, París.

Torres Balbás, L., 1955, Artes almorávide y almohade, Madrid.

- 1963, "Játiva y los restos del palacio de Pinohermoso», Al-Andalus, XXIII, Fasc. 1, pp. 143-171.

Vallejo Triano, A., 2010, La ciudad califal de Madînat al-Zahrâ. Arqueología de su excavación, Córdoba.
Van Staevel, J. P., 1995, «Casa, calle y vecindad en la documentación jurídica», Casas y palacios de al-Andalus. Siglos XII y XIII, Barcelona-Madrid, pp. 53-61. Villanueva, J. de, 1827, Arte de Albañilería, Madrid, ed. facsímil con intro. de J. Gómez de Parada, Madrid, 1977.

Recibido: 9 de junio de 2011 Aceptado: 26 de septiembre de 2011 


\section{Arqueología de la Arquitectura}

\section{Sumario}

Teoría y Método/Theory and Method

Dating mortars: three medieval Spanish architectures

Datando argamasas. Tres ejemplos de arquitectura medieval hispana

Juan Antonio Quirós Castillo, Fabio Marzaioli y Carmine Lubritto

Láser escáner y nubes de puntos. Un horizonte aplicado al análisis arqueológico de edificios

Laser scanner and point cloud. A horizon applied to the archaeological analysis of buildings

Ismael García-Gómez, Miren Fdez. de Gorostiza López de Viñaspre y Amaia Mesanza Moraza

Estudios/Studies

Arquitectura defensiva en el Castro de Castromaior (Lugo). Análisis de las técnicas constructivas en el acceso al recinto central del poblado

Defensive architecture in the fort of Castromaior (Lugo). The analysis of the building techniques of the access to the main enclosure of the village

Miguel Ángel López Marcos, Yolanda Álvarez González y Luis Francisco López González

"Aqvedvctivm". Una lectura tridimensional en la Forma Urbis Marmorea

"Aqvedvctivm". A three-dimensional reading of the Forma Urbis Marmorea

Antonio Monterroso Checa

Materiales y técnicas constructivas en la Murcia andalusí (siglos X-XIII)

Materials and building techniques in the andalusian Murcia (10-13 ${ }^{\text {th }}$ centuries)

Julio Navarro Palazón y Pedro Jiménez Castillo

Estudio histórico-estratigráfico de los muros de la nave central de la catedral de Teruel y su encuentro con la techumbre

Historical and stratigraphical study of the walls of the main aisle of the Cathedral of Teruel and their joints with the roof

Berta de Miguel Alcalá y Gabriel Pardo Redondo

De Palacio a Monasterio. Génesis y transformación del Real Monasterio de Santa Clara de Sevilla

From Palacio to Monastery. Genesis and transformation of the Royal Monastery of Santa Clara in Seville

Pablo Oliva Muñoz y Miguel Ángel Tabales Rodríguez

Evolución del color en el alero de la fachada del rey D. Pedro I, Real Alcázar de Sevilla. Aportaciones del estudio de materiales a la identificación de las intervenciones de restauración a lo largo de su historia

The evolution of the colour in the eaves of the facade of the palace of the king Pedro I, Royal Palace of Seville.

Contribution of the study of materials to the identification of the conservation works undertaken throughout its history

Olimpia López Cruz, Ana García Bueno y Víctor J. Medina Flórez

Arqueología de la Arquitectura y Urbanismo de la ciudad de Oviedo (Asturias, España) entre la Edad Media y el siglo XVIII: el arrabal del Carpio

Archeology of Architecture and urbanism of Oviedo (Asturias, Spain) between the Medieval Ages and the $18^{\text {th }}$ century:

the Carpio arrabal

Iván Muñiz López

Dal castrum altomedievale al restauro settecentesco: storia e archeologia del castello di Sorrivoli (Roncofreddo - FC)

From the early medieval castrum to the eighteenth-century restoration: history and archaeology of the castle of Sorrivali (Roncofreddo - FC)

Andrea Fiorini

Murature di mattoni medioevali a vista e resti di finiture a Venezia

Medieval brick walls and finishing surface remains in Venice

Angela Squassina 